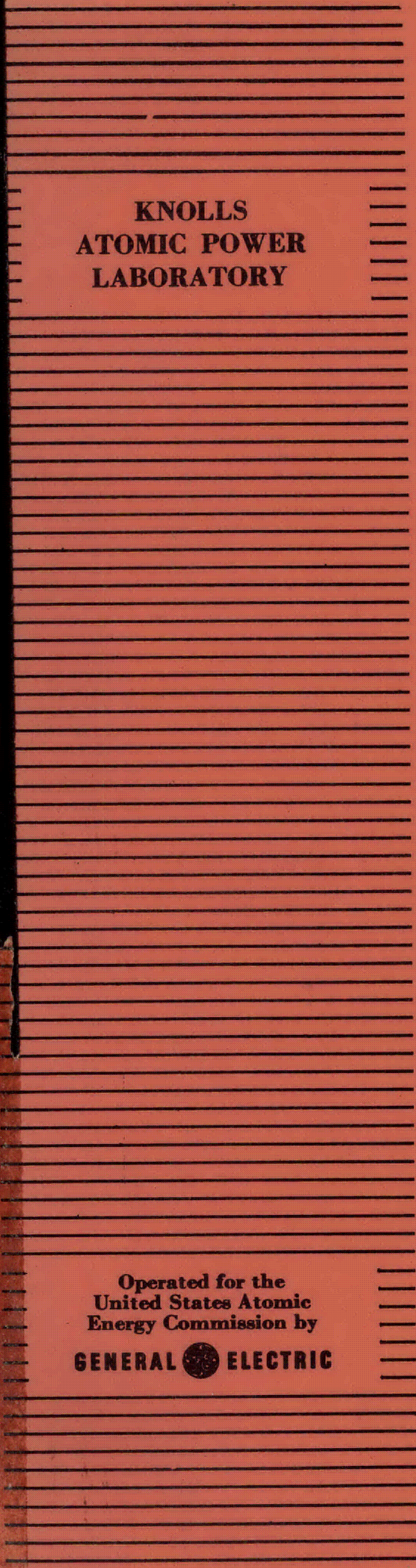

\title{
Mechanical Properties of Zircaloy-2
}

R. L. Mehan F. W. Wiesinger

February 1, 1961 

KAPL-2110

UC-25 Metallurgy and Ceramics

(TID-4500, 15th Edition)

MECHANICAL PROPERTIES OF ZIRCALOY-2

R. L. Mehan

F. W. Wiesinger

February 1, 1961
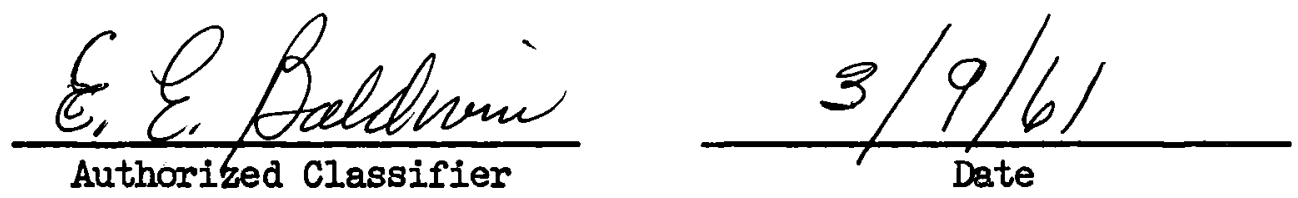

General Electric Company

KNOLIS ATONIC POWER IABORATORY

Schenectady, New York

Operated for the

United States Atomic Energy Commission

Contract No. W-31-109 Eng-52 
UNCLASSIFIED

LEGAL NOTICE

This report was prepared as an account of Governmentsponsored work. Neither the United States, nor the Commission, nor any person acting on behalf of the Commission:

A. Makes any warranty or representation, expressed or implied, with respect to the accuracy, completeness, or usefulness of the information contained in this report, or that the use of any information, apparatus, method, or process disclosed in this report may not infringe privately owned rights; or

B. Assumes any liabilities with respect to the use of, or for damages resulting from the use of any information, apparatus, method, or process disclosed in this report.

As used in the above, "person acting on behalf of the Commission" includes any employee or contractor of the Commission, or employee of such contractor, to the extent that such employee or contractor of the Commission, or employee of such contractor prepares, disseminates, or provides access to, any information pursuent to his employment or contract with the Commission, or his employment with such contractor.

Printed in USA. Price $\$ 1.50$. Available from the Office of Technical Services, Department of Commerce, Washington 25, D. C. 
KAPL-2710

UC-25 Metallurgy and Ceramics

(TID-4500-16th Edition)

Internal Distribution

No. of Copies

AEC, SNROO

Anderson, WK

1

Baldwin, EE

1

Beard, AP

2

Beck, CJ

Beitscher, $S$

$\mathrm{Bibb}, \mathrm{AE}$

Bier, CJ

Brown, HF

Ceshin, W

Cooper, WE

Denzer, DM

Document Library

Enrico, RJ

Fleischmann, WL

Fritz, RJ

Hendrickson, KR

Johansson, EB

Jorgensen, DH

Kephart, AR

Knox, WM

Kunz, FW

Lacy, CE

Levy, A

Lozier, $P G$

Lupi, RF

Margulis, W

Matuszyk, CP

McCalley, RB

Mehan, RL

Miller, IR

Miller, $\mathrm{SH}$

Probstel, RA

Savidge, RE

Seymour, WE

Simon, RJ

Sokol, GJ

Stahl, CR

Swales, TG

1

1

1

1

1

1

1

1

1

4

1

1

1

1

1

1

1

1

1

1

1

1

1

1

1

1

15

1

1

1

1

1

1

1

1

1 
Internal Distribution (continued)

Swota, J

Technical Publications/Shaw, JG

TIG/Schmidt, CJ

Truman, JC

Whitehead, AD

Wiesinger, FW

Zeno, RS

External Distribution

Aberdeen Proving Ground 2

Aerojet-General Corporation 1

Aerojet-General Nucleonics 1

AFPR, Boeing, Seattle 1

AFPR, Lockheed, Marietta 2

ANP Project Office, Convair, Fort Worth 2

Alco Products, Inc.

Allis-Chalmers Manufacturing Company 1

Allis-Chalmers Manufacturing Company, Washington 1

Allison Division - GMC 1

Argonne National Laboratory 10

Armour Research Foundation I

Army Ballistic Missile Agency 1

AEC Scientific Representative, Belgium 1

AEC Scientific Representative, France 1

AEC Scientific Representative, Japan 1

Atomic Energy Commission, Washington 3

Atomic Energy of Canada Limited 4

Atomics International 4

Babcock and Wilcox Company 4

Battelle Memorial Institute 2

Beryllium Corporation 1

Bridgeport Brass Company 1

Bridgeport Brass Company, Adrian 1

Brookhaven National Laboratory 2

Brush Beryllium Company 1

Bureau of Mines, Albany 1

Bureau of Ships (Code 1500) 1

Carborundum Company 1

Chicago Operations Office 3

Chicago Patent Group 1

Clevite Corporation 1 
KAPL-2110

External Distribution (continued)

No. of Copies

Combustion Engineering, Inc.

Combustion Engineering, Inc. (NRD)

Convair-General Dynamics Corporation, San Diego 1

Defence Research Member

Denver Research Institute

1

Department of the Army, G-2

Dow Chemical Company (Rocky Flats)

duPont Company, Aiken

duPont Company, Wilmington

Frankford Arsenal

Franklin Institute of Pennsylvania

General Atomic Division

General Electric Compeny (ANPD)

Ceneral Electric Company, Richland

General Electric Company, St. Petersburg

General Nuclear Engineering Corporation

Glasstone, Samuel

Goodyear Atomic Corporation

Grand Junction Operations Office

Iowa State University

Jet Propulsion Laboratory

Johns Hopkins University (ORO)

Ios Alamos Scientific Laboratory

Ios Alamos Scientific Laboratory (Sesonske)

M \& C Nuclear, Inc.

Mallinckrodt Chemical Works

Maritime Administration

Martin Company

Mound Laboratory

NASA Lewis Research Center

National Bureau of Standards

National Bureau of Standards (Library)

National Carbon Company

National Lead Company of Ohio

Naval Research Laboratory

New Brunswick Area Office

New York Operations Office

Northern Research and Engineering Corporation

Nuclear Development Corporation of America

Nuclear Materials and Equipment Corporation Nuclear Metals, Inc.

Oak Ridge Institute of Nuclear Studies 
KAPL-2110

External Distribution (continued)

No. of Copies

Office of Naval Research

Office of Naval Research (Code 422)

Olin Mathieson Chemical Corporation

Ordnance Materials Research Office

Ordnance Tank-Automotive Command

Patent Branch, Washington

Phillips Petroleum Company (NRTS)

Picatinny Arsenal

Power Reactor Development Company

Pratt and Whitney Aircraft Division

Rensselaer Polytechnic Institute

Sandia Corporation, Albuquerque

Stevens Institute of Technology (Comstock)

Sylvania Electric Products, Inc.

Technical Research Group

Tennessee Valley Authority

Union Carbide Metals Company

Union Carbide Nuclear Company (ORGDP)

1

1

Union Carbide Nuclear Company (ORNL)

Union Carbide Nuclear Company (Paducah Plant)

USAF Project RAND

U. S. Geological Survey, Denver

U. S. Geological Survey, Menlo Park

U. S. Geological Survey, Washington

U. S. Naval Postgraduate School

U. S. Patent Office

Iniversity of Califormia, Berkeley

University of California, Livermore

University of Puerto Rico

Watertown Arsenal

Westinghouse Bettis Atomic Power Laboratory

1

1

3

1

2

1

1

Westinghouse Electric Corporation

Wright Air Development Division

Yankee Atomic Electric Company

Office of Technical Information Extension

Office of Technical Services, Washington 


\section{CONTENTS}

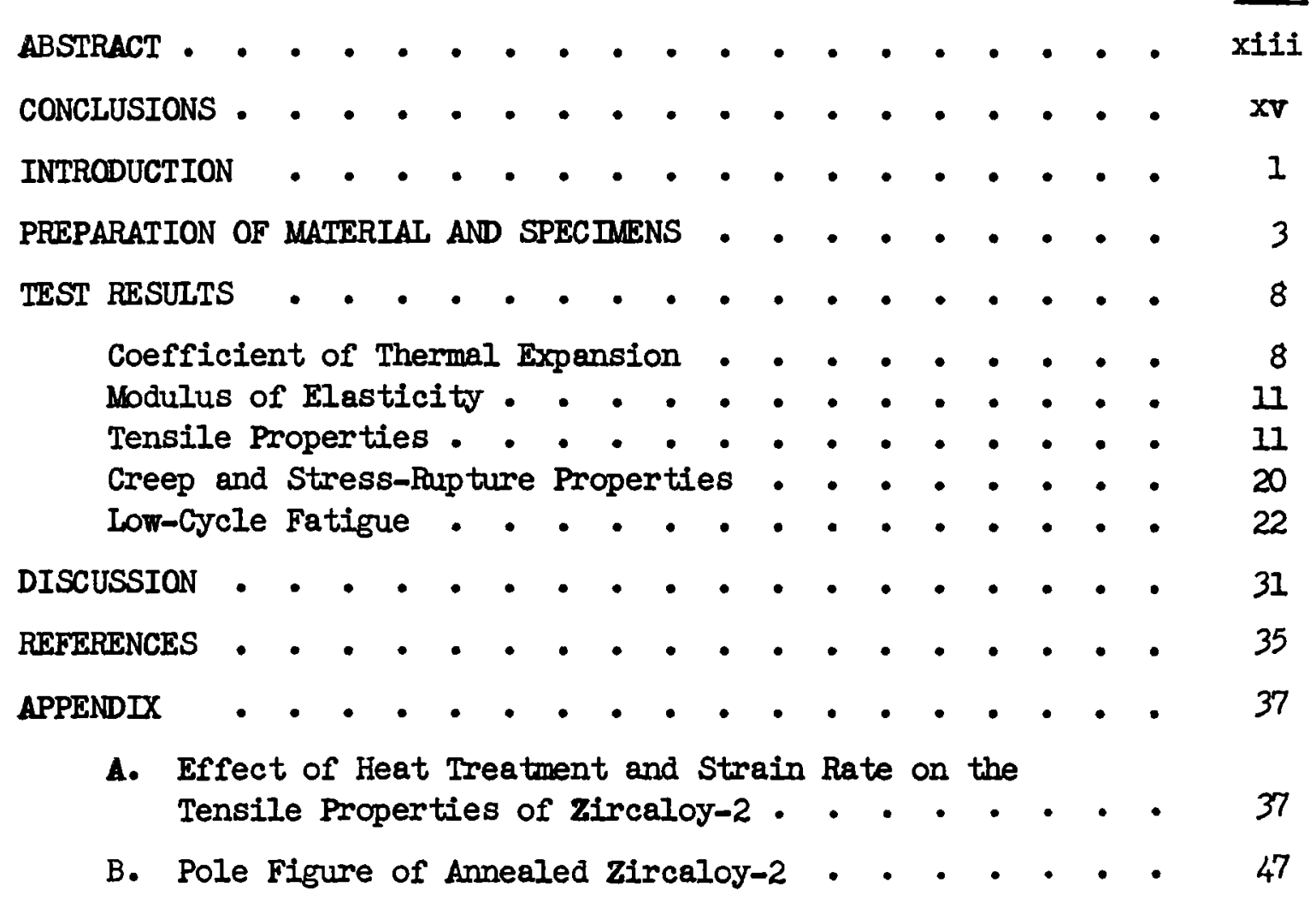




\section{ILLUSTRATIONS}

Figure

Title

$\underline{\text { Page }}$

1 Photomicrographs of Annealed Zircaloy-2 in the Three Principal Directions (KS-40897, Unclassified). . . . 5

2 Creep, Rupture, and Tensile Specimen (KS-40646, Unclassified) . . . . . . . . . . . . 6

3 Creep Test Specimen (KS40657, Unclassified) . • . • 6

4 Sub-size Cyclic Strain Fatigue Specimen (KS-40658, Unclassified) • . . . . . . . . . . . 6

5 Dynamic Modulus Specimen (KS-40727, Unclassified) • . . 6

6 Thermal Expansion Specimen (KS-40829, Unclassified) . . 6

7 Metallographic Structure of Large-Grain Zircaloy-2

Obtained by Critical Straining and Annealing (KS-40893, Unclassified) . . • . . . . . . . . . 7

8 Notch Details of Tensile, Stress-Rupture and Low-Cycle Fatigue Specimens (KS-40830, Unclassified). . . . . . 7

9 Expansion vs Temperature for Zircaloy in the Three Principal Directions to Rolling (KS-40831, Unclassified) . 10

10 Typical Thermal Dilatation Curve for Zircaloy-2

Longitudinal to the Rolling Direction (KS-21725, Unclassified) . . . . . . . . . . . . 10

11 Modulus of Elasticity of Zircaloy-2 vs Temperature (KS-40845, Unclassified). . . . . . . . . . 12

12 Effect of Hydrogen Content, Grain Size, and Temperature on the $0.2 \%$ Yield Strength of Zircaloy-2 Tested Longitudinally to Rolling (KS-40846, Unclassified) . • . 17

13 Effect of Hydrogen Content, Grain Size, and Temperature on the Ultimate Tensile Strength of Zircaloy-2 Tested Longitudinally to Rolling (KS-40847, Unclassified) . • . 17

14 Effect of Hydrogen Content, Grain Size, and Temperature on the Reduction of Area of Zircaloy-2 Tested Longitudinally to Rolling (KS-40848, Unclassified) . • . 17

15 Effect of Notches on the Tensile Properties of Zircaloy-2 with Two Hydrogen Contents and Two Grain Sizes (KS-40849, Unclassified) 
16 Effect of Hydrogen Content and Temperature on the Tensile Properties of Fine-Grained Zircaloy-2 Tested in the Transverse Direction to Rolling (KS-40850, Unclassified)

17 Effect of Notches on the Tensile Properties of FineGrained Zircaloy-2 Tested in the Transverse Direction to Rolling (KS-40851, Unclassified) . . . . . . .

18 Comparison of the Tensile Properties of Zircaloy-2 Tested in the Longitudinal and Transverse Direction to Rolling (KS-40852, Unclassified)

19 Ellipticality Ratio vs Test Temperature for Zircaloy-2 Tensile Specimens (KS-27889, Unclassified). . . . . . 18

20 True Stress - True Plastic Strain curves for Zircaloy-2 with $12 \mathrm{ppm}$ Hydrogen to the Limit to Uniform Elongation (KS-40853, Unclassified). • • • • • • • • • • . 18

21 Rate Sensitivity of Zircaloy-2 vs Temperature for the Longitudinal and Transverse Direction to Rolling (KS-40855, Unclassified).

22 Stress Required for Various Amounts of Total Deformation for Zircaloy-2 Tested Longitudinally to the Rolling Direction at $3000 \mathrm{~F}$ (KS-40856, Unclassified) . • . • 25

23 Stress Required for Various Amounts of Total Deformation for Zircaloy-2 Tested Longitudinally to the Rolling Direction at $600 \circ \mathrm{F}$ (KS -40857 , Unclassified)

24 Stress Required for Virious Amounts of Total Deformation for Zircaloy-2 Tested Longitudinally to the Rolling Direction at $800 \circ \mathrm{F}$ (KS-40858, Unclassified) . . . . . 25

25 Stress Required for Various Amounts of Total Deformation for Zircaloy-2 Tested Longitudinally to the Rolling Direction at $1000 \circ \mathrm{F}$ (KS -40859 , Unclassified) . . . . 25

26 Rupture Strength of Zircaloy-2 Tested Longitudinally to the Rolling Direction (KS-40860, Unclassified) . . . . 25

27 Stress Required for Various Amounts of Total Deformation for Zircaloy-2 Tested Transverse to the Rolling Direction at $300 \circ \mathrm{F}$ (KS-40861, Unclassified)

28 Stress Required for Various Amounts of Total Deformation for Zircaloy-2 Tested Transverse to the Rolling Direction at $600 \circ \mathrm{F}$ (KS-40862, Unclessified). 
29 Stress Required for Various Amounts of Total Deformation for Zircaloy-2 Tested Transverse to the Rolling Direction at $800 \circ \mathrm{F}$ (KS-40863, Unclassified). . • • . • . . 26

30 Stress Required for Various Amounts of Total Deformation for Zircaloy-2 Tested Transverse to the Rolling Direction at $1000 \% \mathrm{~F}$ (KS-40864, Unclassified) . . • . . . 26

31 Rupture Strength of Zircaloy-2 Tested Transverse to the Rolling Direction (KS-40865, Unclassified). . . . . . 26

32 Effect of $500 \mathrm{ppm}$ Hydrogen on Rupture Strength and Ductility at Three Temperatures for Zircaloy-2 Tested Longitudinally or to the Rolling Direction (KS-40866, Unclassified)

33 Rupture Strength of Notched and Unnotched Zircaloy-2 Tested Longitudinally to the Rolling Direction (KS-40867, Unclassified)

34 Strain Range vs Cycles to Failure for Zircaloy-2 Tested in the Longitudinal Direction to Rolling (KS-40871, Unclassified) 。 . . . . . . • . . . • .

35 Stress Range vs Cycles to Failure for Zircaloy-2 Tested in the Longitudinal Direction to Rolling (KS-40872, Unclassified)

36 Strain Range vs Cycles to Failure for Zircaloy-2 Tested in the Transverse Direction to Rolling (Fine-Grained Condition, $12 \mathrm{ppm} \mathrm{H}_{2}$ ) (KS-40873, Unclassified) . . . . . .

37 Stress Range vs Cycles to Failure for Zircaloy-2 Tested in the Transverse Direction to Rolling (Fine-Grained Condition, $12 \mathrm{ppm} \mathrm{H}_{2}$ ) (KS-40874, Unclassified) . . . . . . .

38 Effect of $500 \mathrm{ppm} H y d r o g e n$ Content on the Room Temperature Fatigue Properties of Zircaloy-2 and Comparison of Longitudinal and Transverse Fatigue Properties (KS-40875, Unclassified)

39 Effect of Notches and Hydrogen Content on the Room Temperature Fatigue Properties of Zircaloy-2 Tested in the Longitudinal Direction to Rolling (KS-40876, Unclassified)

40 Effect of Hydrogen Content on the $600 \% \mathrm{~F}$ Fatigue Properties of Zircaloy-2 Tested in the Longitudinal Direction to Rolling (KS-40877, Unclassified) 
41 Effect of Hydrogen Content and Grain Size on the $600 \%$ Fatigue Properties of Zircaloy-2 Tested in the Longitudinal Direction to Rolling (KS-40878, Unclassified) 30

42 Interrupted Stress-Strain Curve for Zircaloy-2 at Room Temperature (KS-40879, Unclassified). . . . . . . 33

A.1 Typical Photomicrographs of Fine-Grain Heat-Treated Zircaloy-2 (KS-40894, Unclassified) . . . . . . . 39

A.2 Typical Photomicrographs of Intermediate-Grain HeatTreated Zircaloy-2 (KS-40895, Unclassified) . . . . 40

A.3 Typical Photomicrographs of Large-Grain Heat-Treated Zircaloy-2 (KS-40896, Unclassified) . . . . . . . 41

A.4 Effect of Strain Rate on Tensile and Yield Strengths of Zircaloy-2 at Room Temperature with Various Heat Treatments (KS-21727, Unclassified) . . . . . . 42

A.5 Effect of Strain Rate on Ductility of Zircaloy-2 at Room Temperature with Various Heat Treatments (KS-21728, Unclassified)

A.6 Effect of Crain Size on Tensile and Yield Strength of Zircaloy-2 at Room Temperature with Various Heat Treatments (KS-21729, Unclassified)

A.7 Effect of Grain Size on Ductility of Zircaloy-2 at Room Temperature with Various Heat Treatments (KS-22730, Unclassified) . . . . . . . . . . . . . . 43

A.8 Effect of Grain Size on Tensile and Yield Strengths of Zircaloy -2 at $600 \%$ with Various Heat Treatments (KS-21731, Unclassified) . . . . . . . . . . 44

A.9 Effect of Crain Size on Ductility of Zircaloy-2 at $600 \% \mathrm{~F}$ with Various Heat Treatments (KS-21732, Unclassified) . . 44

A.10 Effect of Strain Rate on Tensile Properties of Notched and Unnotched Zircaloy-2 (KS-21733, Unclassified). . . . 45

A.II Effect of Hydrogen Content on Tensile Properties of Notched and Unnotched Zircalcy-2 at Room Temperature and Two-Strain Rates (KS-21734, Unclassified) . . . . . 45

A.12 Schematic Diagram of "ivotch Brittle" Behavior (KS-41058, Unclassified) . . . . . . . . . . . . • 46

B.1 Pole Figure for Annealed Zircaloy-2 (KS-4I553, Unclassified) 



\begin{abstract}
The mechanical and physical properties of Zircaloy-2 were determined as a function of five test variables: temperature, grain size, direction to rolling, hydrogen content, and the presence or absence of a notch. The investigation included studies of the coefficient of thermal expansion, elastic modulus, tensile properties, creep properties, and low-cycle fatigue properties. Approximately 470 specimens from a single ingot were tested in the course of the investigation.
\end{abstract}




\section{ACKNOWLEDGEMENTS}

The authors wish to acknowledge the contributions of G. I. Cutler, W. A. Riemen, and J. Swota to the experimental work and tabulation of the data. 


\section{CONCLUSIONS}

The following conclusions are drawn from the results of the tests performed in this investigation of mechanical and physical properties of Zircaloy-2.

The anisotropic character of Zircaloy-2 is manifested in many ways. The coefficient of thermal expansion is different in the three directions to rolling, although the elastic modulus does not seem to be af fected at room temperature. If the transverse direction to rolling is considered in comparison with the longitudinal direction, the yield strength is higher, the tensile strength is lower, the ductility is higher, the creep strength is lower, and the low-cycle strain fatigue strength is lower. These relationships hold true independently of temperature.

Although hydrogen content up to $500 \mathrm{ppm}$ can affect tensile strength, stress-rupture, and fatigue properties, the effect is not large. In no static case did the uniaxial unnotched ductility drop below $20 \%$ strain or the notched ductility below $6 \%$ strain.

Zircaloy-2 seems to be notch insensitive in its uniaxial tensile properties under both short-time behavior (notched tensile tests) and long-time behavior (notched rupture tests).

The fatigue notch sensitivity factor for Zircaloy-2 is quite low, in the order of $0.1\left(K_{f}=1.77\right.$ when $\left.K_{t}=8.0\right)$.

An increase in grain size of Zircaloy-2 tends to reduce the tensile strength and ductility, but only to a small extent. The notched fatigue strength at $600^{\circ} \mathrm{F}$ is reduced by the presence of large grains.

Zircaloy-2 seems to undergo a strain-aging reaction at a temperature in the neighborhood of $600 \circ \mathrm{F}$. This is manifested by a discontinuity in the curve of tensile properties versus temperature, low creep rates at $600 \mathrm{~F}$, and a discontinuity in the values of strain rate sensitivity versus temperature. 

MECHANICAL PROPERTIES OF ZIRCALOY-2

R. L. Mehan, F. W. Wiesinger

\section{INIRODUCTION}

Zircaloy-2 is a zirconium-tin alloy developed for use in watercooled nuclear reactors. It possesses good corrosion resistance to high-temperature water, excellent nuclear characteristics, and sufficiently good mechanical properties for use as a structural material in reactor cores and as a fuel element material. The mechanical and physical properties of major concern for reactor components are as follows:

1. Short-time strength and ductility

2. Long-time strength and ductility

3. Low-cycle fatigue

4. Physical properties such as elastic modulus, coefficient of thermal expansion, Poisson's ratio, and thermal conductivity.

The above properties must be studied as a function of operating variables representative of conditions in service that might affect the mechanical and physical properties. A complete study of all the factors involved would lead to an exceedingly long and expensive investigation. Furthermore, it is not necessary to study the effects of all the variables on all the properties, either because the effect is known from previous work or because it can be expected to have little effect.

The purpose of the investigation described in this report was to obtain information, primarily for engineering design, concerning most of the properties listed and how these properties are affected by some of the variables that are representative of service conditions. No claim is made to complete coverage of all the factors that might affect the performance of zircaloy-2. Several of the more important factors, such as radiation damage and the effect of a high-temperature water environment, are not considered. The factors chosen for study were those that could be obtained readily by conventional laboratory procedures and, at the same time, represented important operating variables.

Temperature, of course, has a pronounced effect on metal properties. Although the nominal operating temperatures of water-cooled reactors are 
in the neighborhood of $600 \% \mathrm{~F}$, at times it is necessary to know the effects of higher and lower temperatures on mechanical properties. Consequently, the effect of temperature in the range of room temperature to $1100^{\circ} \mathrm{F}$ was studied.

Another important factor that affects the performance of Zircaloy-2 is the development by conventional fabrication techniques of a high degree of preferred orientation in the material. Zircaloy-2 has a hexagonal, close-packed structure and, as is typical of this class of material, exhibits marked anisotropic mechanical properties. The effect of directionality constituted the second test variable.

The effect of hydrogen on mechanical properties was determined. From previous work reported by F. Forscher, 1 hydrogen is known to have an effect, generally detrimental, on the mechanical characteristics of Zircaloy-2. During service, hydrogen may be picked up by the metal as a result of corrosion and the radiation decomposition of water; subsequently, this hydrogen may diffuse to the cooler regions of the structure in question. Hydrogen content in the order of $500 \mathrm{ppm}$ or higher may be obtained under certain conditions, although in general the level is considerably lower.

The grain size of a metal affects both low- and high-temperature strength. Although Zircaloy-2 is fine-grained in most applications, at times large coarse grains may be present. This condition may be the result of critical straining followed by a recrystallization heat treatment, thermal effects adjacent to a weld, or other causes. In this investigation the effect of small and large grains was considered.

Finally, the effect of notches on tensile, fatigue, and creep properties was studied. Notches exist in components for a variety of reasons, both intentional and unintentional, and under certain conditions (primarily fatigue loading) may give rise to premature failure.

Earlier studies of Zircaloy $-2^{2}, 3,4,5$ revealed the general mechanical behavior of this material as it is-affected by some of the above variables. However, a systematic investigation of the effects of these variables on a single ingot of Zircaloy-2 is lacking. The present study is an attempt to fill this need. 
PREPARATION OF MATERIAL AND SPECIMENS

Vacuum-melted Zircaloy-2 was used throughout this investigation. The complete fabrication history is shown in Table 1. The chemical analysis is shown in Table 2. Photomicrographs of the material in the annealed condition in the three principal directions with respect to rolling are shown in Figure 1. The grain size is about ASTM 7 to 8 (ferrous standard). It is pointed out that the material intentionally was given a large cold-reduction (25\%) on the final rolling pass to simulate more closely the degree of preferred orientation in thin sections, which are normally produced with fairly large cold-reductions. The amount of preferred orientation developed was determined by means of X-ray diffraction techniques and a pole figure was obtained. The results are presented in Appendix B.

The test specimens used for the determination of mechanical and physical properties are shown in Figures 2 to 6. All the material was tested in the asmannealed condition, and every effort was made to keep the fabrication of specimens for different tests as uniform as possible to enable direct comparisons to be made. Specimens were tested in both the longitudinal and transverse directions to rolling in order to study the anisotropy. For studying the coefficient of thermal expansion, specimens normal to the rolling plane were tested. To minimize inhomogenities in the as-received rolled plates, the specimens were removed randomly in groups of 10 to 20 along the length of the plate.

TABLE 1. FABRICATION HISTORY OF ZIRCALOY-2 SPECIMENS

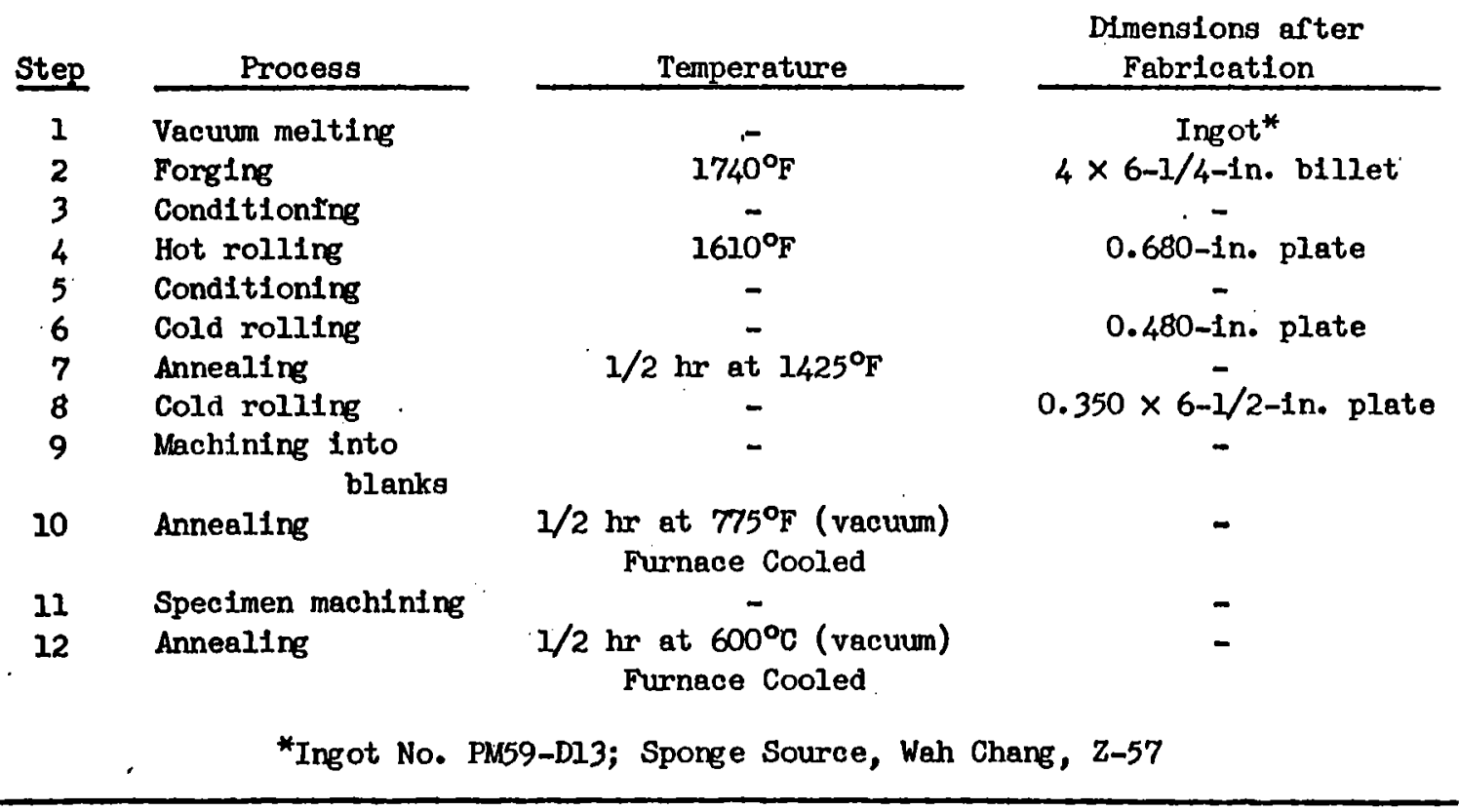


TABLE 2. CHEMICAL ANALYSIS OF ZIRCALOY -2

\begin{tabular}{|c|c|c|}
\hline Element & Amount, ${ }^{*} \mathrm{ppm}$ & Analyolo Technique \\
\hline Tin & $1.53 \%^{* *}$ & Polarograph1o \\
\hline Iron & 1550 & Chemtoal \\
\hline Chromium & 863 & Chemical \\
\hline N1ckle & 493 & Chemical \\
\hline Nitrogen & 41 & KJeldahl . \\
\hline Carbon & 400 & Combustion \\
\hline Oxygen & 883 & Vacuum fusion \\
\hline Hydrogen & 12 & Vacuun fusion \\
\hline Aluminum & 63 & Spectrographic \\
\hline Boron & 0.3 & Spectrographlo \\
\hline Cadmium & $<0.3$ & Spectrogrephto \\
\hline Cobalt & $<2$ & Spectrographio \\
\hline Copper & 29 & Spectrographic \\
\hline Hafnium & $<40$ & Spectrographio \\
\hline Magnesium & $<10$ & Spectrographto \\
\hline Manganese & 9 & Spectrographic \\
\hline Molybdenum & $<5$ & Spectrographio \\
\hline Lead & 28 & Spectrographto \\
\hline S1110on & 28 & Spectrographto \\
\hline Titanium & $<\infty 0$ & Spectrographto \\
\hline Vanadium & $<5$ & Spectrographto \\
\hline Tungsten & 38 & Spectrographio \\
\hline
\end{tabular}

Hydriding was performed by a vacuum absorption technique. The specimens, in groups of about six, were inserted into a glass tube furnace, evacuated, and heated to a temperature of 600 to $700^{\circ} \mathrm{C}$. A known volume of hydrogen was admitted into the furnace when the vacuum had reached a value of $3.0 \times 10^{-6} \mathrm{~mm}$ Hg or less. About $5 \mathrm{hr}$ was allowed for hydrogen absorption, after which the specimens were furmace-cooled.

Grain growth was achieved by introducing a known strain (4.3\%) at room temperature, followed by a recrystallization heat treatment of $20 \mathrm{hr}$ in vacuum at $800^{\circ} \mathrm{C}$. This treatment produced a structure of predominantly large grains (ASTM 0 to 2) but mixed with somewhat smaller grains (ASTM 3 to 5): A typical structure 1s shown in Figure 7. Apparently Zircaloy-2 exhibits discontinuous grain growth in a manner similar to that displayed by tin. ${ }^{\circ}$

The notches used for the tensile and stress-rupture tests were 60-deg V-notches with a 0.005-in. radius. This cross-sectional area at the base of the notch was $50 \%$ of the unnotched cross-sectional area. 


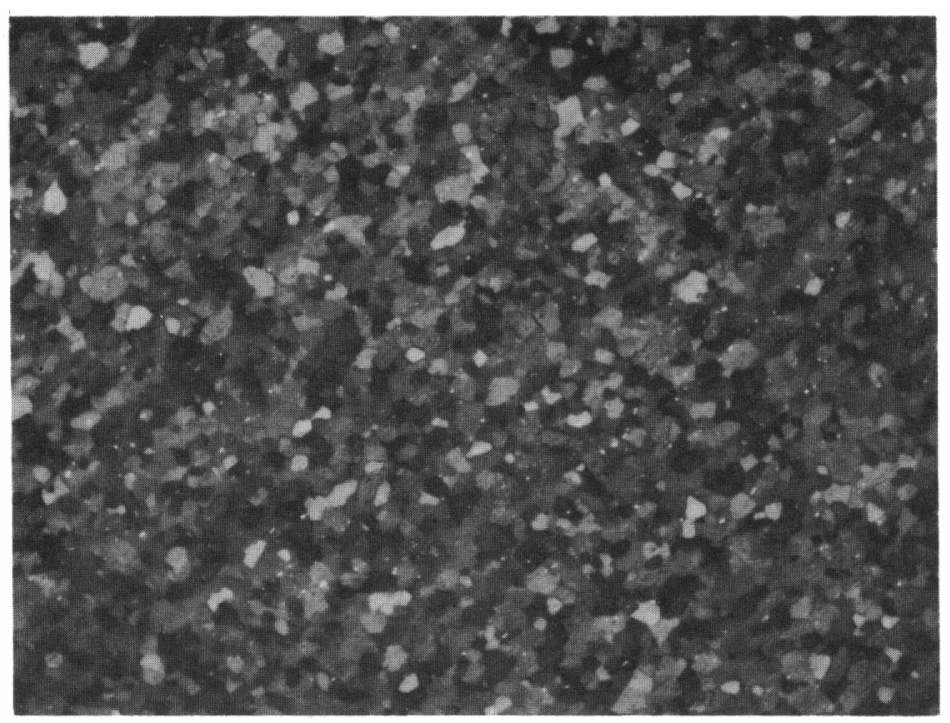

NORMAL TO LONGITUDINAL DIRECTION

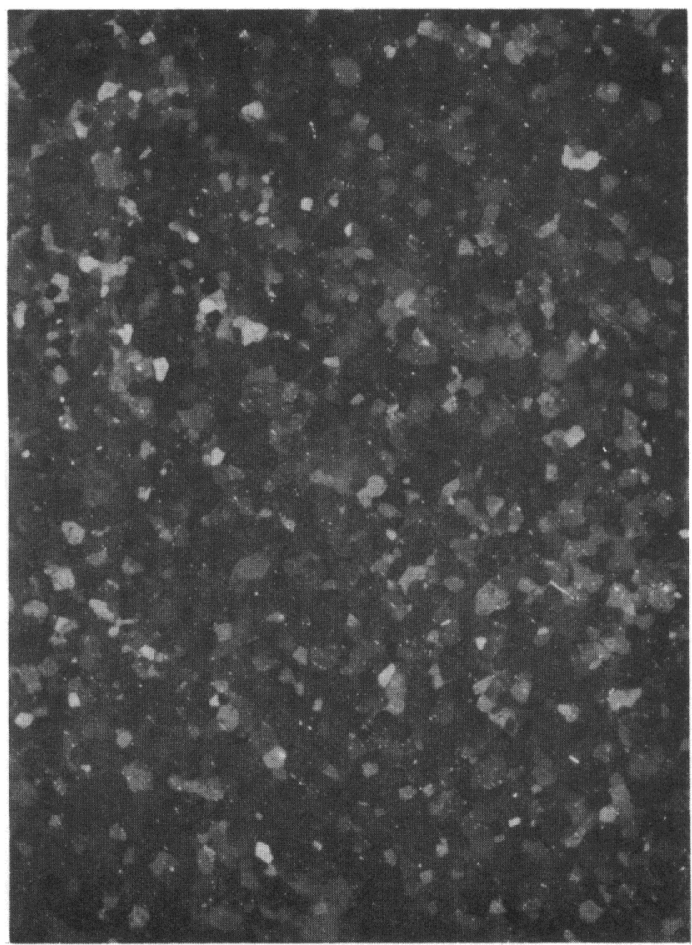

NORMAL TO TRANSYERSE DIRECTION

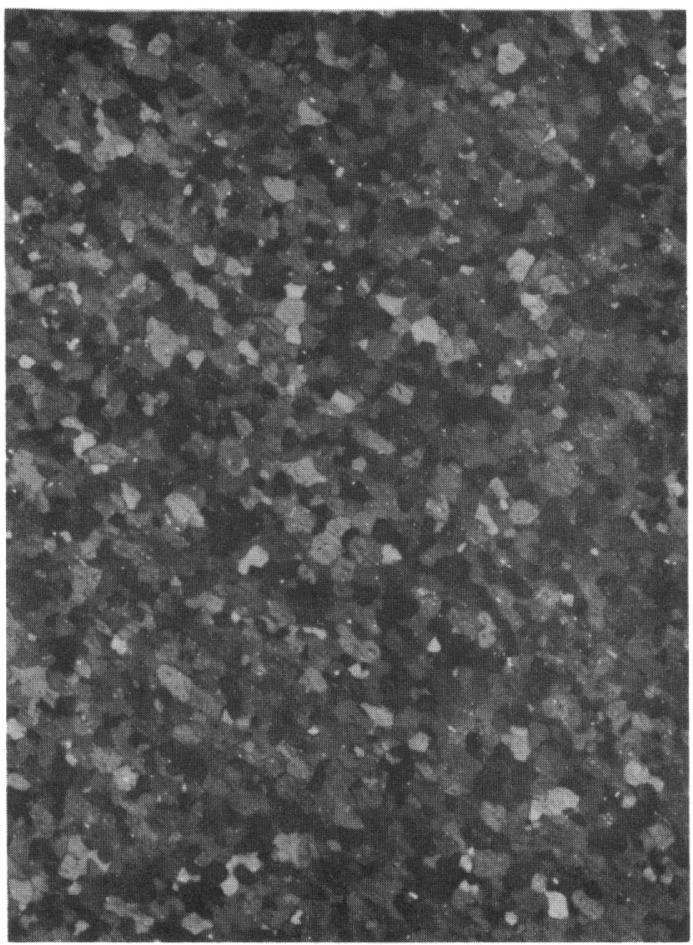

NORMAL TO THICKNESS DIRECTION

FIGURE 1. PHOTOMICROGRAPHS OF ANNEALED ZIRCALOY-2 PLATE IN THE THREE PRINCIPAL DIRECTIONS. POLARIZED LIGHT. 


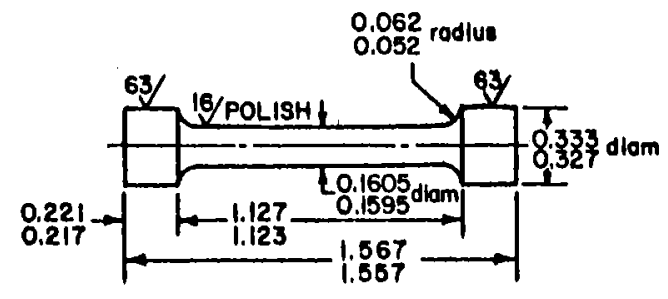

FIGURE 2. CREEP, RUPTURE, AND TENSILE SPECIMEN (DIMENSIONS IN INCHES)

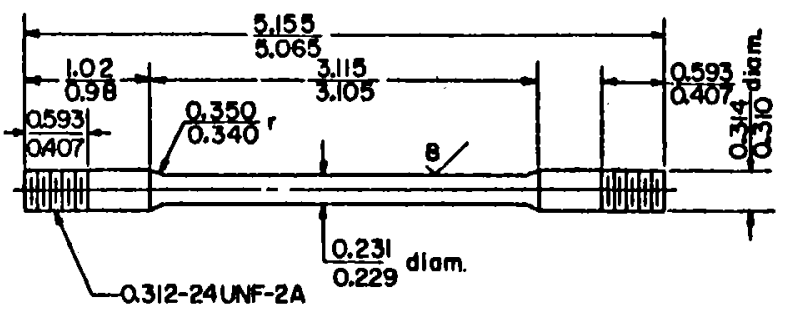

FIGURE 3. CREEP TEST SPECIMEN (DIMENSIONS (N INCHES)

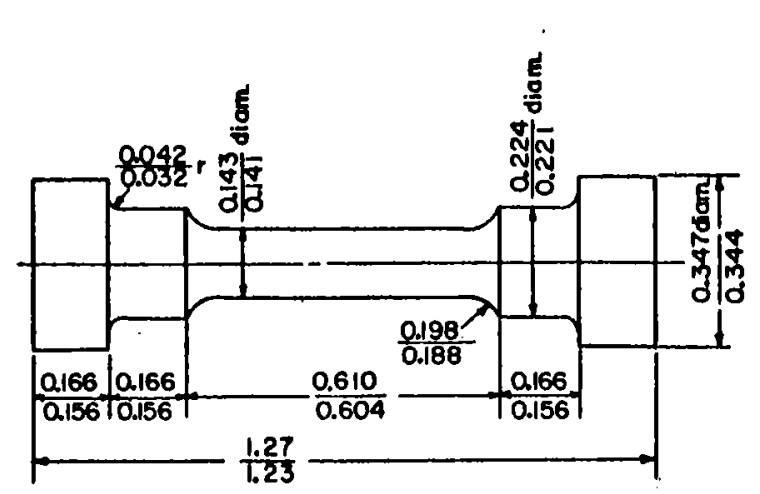

FIGURE 4. SUB-SIZE CYCLIC STRAIN FATIGUE SPECIMEN (DIMENSIONS IN INCHES)

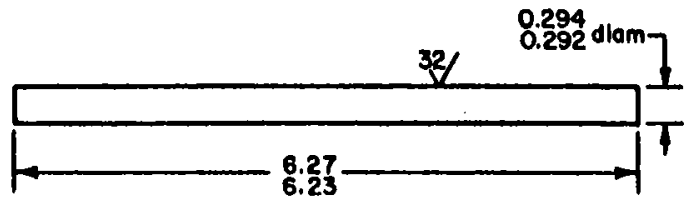

FIGUURE 5. DYNAMIC MODULUS SPECIMEN (DIMENSIONS IN INCHES)

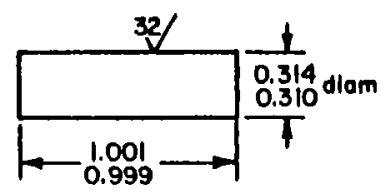

FIGURE 6. THERMAL EXPANSION SPECIMEN (DIMENSIONS IN INCHES)

This type of notch has a theoretical stress concentration factor of about 3.0, and is shown in Figure 8.

The notches used for the low-cycle fatigue tests were of a different variety. It was desired to use a notch with as large a theoretical stress-concentration factor as possible. The type chosen consisted of superimposed notches, one with a large radius and the other quite small. The small notch was lapped by a 0.001-in.-diam tungsten wire covered with 600-grit silicon carbide dispersed in lubrication grease.* The configuration is shown in Figure 8 . On the basis of an experimental study by A. W. Mowbray, ${ }^{7}$ the effect of superimposing two notches gives a theoretical stress concentration of about 0.84 times the product of the two individual factors. However, these results were developed for large flat specimens and, because of this geometrical difference, may not be exactly

*Most of the fatigue specimens were machined with the large-radius notch. When the necessity arose to obtain a larger stress concentration factor, the only readily available method at this point was superimposition of notches. 


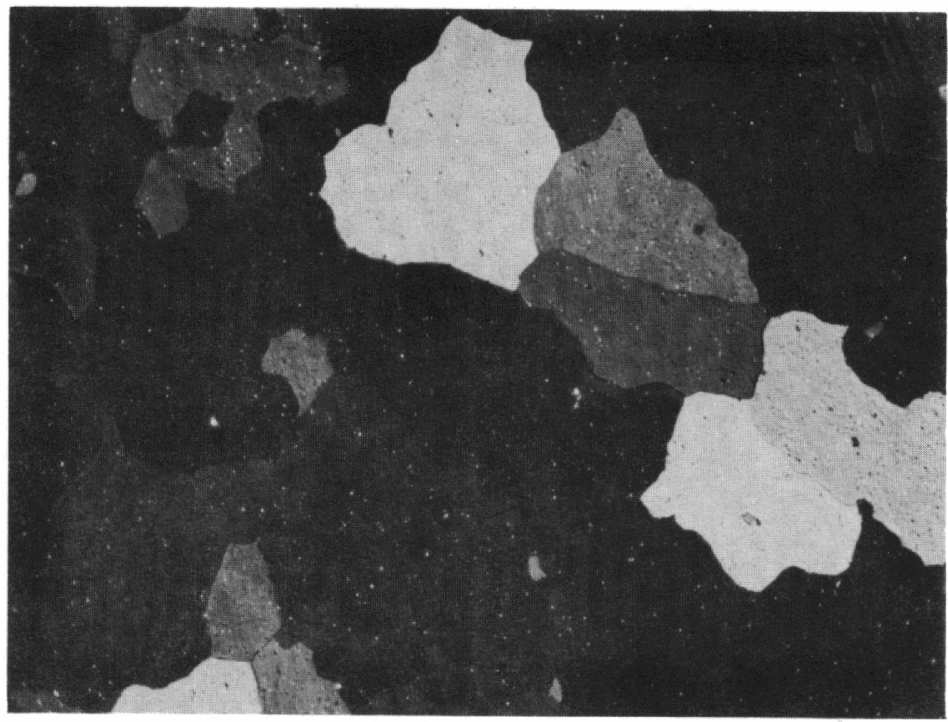

FIGURE 7. METALLOGRAPHIC STRUCTURE OF LARGE-GRAIN ZIRCALOY-2 OBTAINED BY CRITICAL STRAINING AND ANNEALING. POLARIZED LIGHT 100X

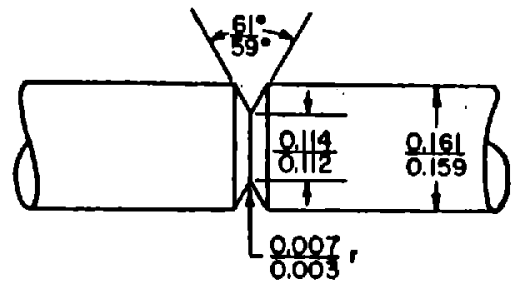

TENSILE AND STRESS-RUPTURE SPECIMEN NOTCH

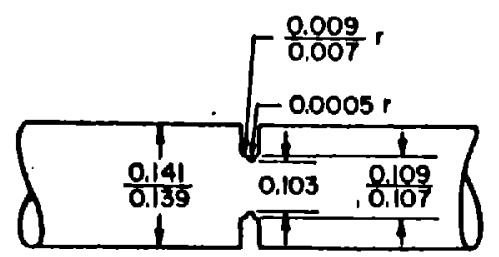

LOW CYCLE FATIOUE SPECIMEN NOTCH

FIGURE 8. NOTCH DETAILS OF TENSILE, 5TRESSRUPTURE, AND LOW CYCLE FATIGUUE SPECIMENS (DIMENSIONS IN INCHES) applicable to a amaller cylindrical spectmen. For purposes of calculating the notch sensitivity factor, $q$, a theoretical stress concentration factor of 8.0 , was used. This is somewhat less than the value of 10.9 calculated by A. W. Mowbray's method and greater then the value of 7.5 resulting from the presence of the small notch alone if it extended the combined distance of both notches.

The fabrication steps for all specimens are given in detail in Table 3. 
TABLE 3. SPECIMEN FABRICATION PROCESS

\begin{tabular}{l} 
Conditions \\
\hline Fine-grained \\
Unnotched \\
Normal hydrogen \\
Fine-grained \\
Unnotched \\
Hydrogen added \\
Coarse-grained \\
Unnotched \\
Normal hydrogen \\
Coarse-grained \\
Unnotched \\
Hydrogen added
\end{tabular}

Any conditions with a machined notch
Stepg

1. Spectmen machining

2. Anneal $1 / 2 \mathrm{hr}$ at $600^{\circ} \mathrm{C}$ in vaouum Furnace cool

3. HF pickle (0.002 In. removal)

1. Specimen machining

2. HF pickle (0.002 in. removal)

3. Itydride at $600^{\circ} \mathrm{C}(\sim 3 \mathrm{hr}$ at temperature) Furnace cool.

1. Specimen machining

2. Strain $4.6 \%$ Anneal $20 \mathrm{hr}$ at $800^{\circ} \mathrm{C}$ in vacuum Furnace cool

3. $\mathrm{HF}$ pickle (0.002 in. removal)

1. Spectmen machining

2. Strain $4.6 \%$ Anneal $20 \mathrm{hr}$ at $800^{\circ} \mathrm{C}$ in vacuum Furnace cool

3. HF pickle (0.002 in. removal)

4. Hydride at $600^{\circ} \mathrm{C}(\sim 3 \mathrm{hr}$ at temperature) Furnace cool

Notch machined as the last fabrication step in all conditions

\section{TEST RESULTS}

\section{Coefficient of Thermal Expansion}

The determination of the coefficient of thermal expansion was performed in a dilatometer. The apparatus consists of a quartz furnace tube connected to a high vacuum system, a furnace, and the specimen holder with its accompanying equipment. A complete description of the equipment has been reported by G. L. Cutler. ${ }^{8}$ Movement of the specimen versus temperature is autographically recorded by means of two linear variable differential transformers connected in series with the necessary control devices. The temperature of the specimen is measured by a thermocouple placed in a hole in the specimen. A vacuum of at least $1 \times 10^{-5} \mathrm{mn} \mathrm{Hg}$ was maintained during each test.

The expansion as a function of temperature up to $1472^{\circ} \mathrm{F}$, for the three principal directions to rolling, is plotted in Figure 9. The specimens were heated and cooled at a rate of $100^{\circ} \mathrm{C} / \mathrm{hr}^{*}$ and were heated

*Several check runs showed that the thermal expansion is unaffected by a slower heating/cooling rate of $50^{\circ} \mathrm{C} / \mathrm{hr}$. 
to a maximum temperature of $1000^{\circ} \mathrm{C}$. The expansion data shown in Figure 9 were taken from the heating curve only. The experimental points fall on three curves, corresponding to each of the three principal directions to rolling.* The middle curve, representative of transverse specimens, is a good average of all three directions.

The data shown in Figure 9 can be expressed by empirical equations, as shown below. Although the transverse data can be fitted a little better by a quadratic expression, the error in a linear fit is considered small and is more useful for engineering calculations.

$$
\begin{array}{ll}
\mathrm{I}_{\mathrm{t}}=\mathrm{I}_{0}\left(1+4.62 \times 10^{-6} \Delta \mathrm{T}\right) & \text { Longitudinal direction to rolling } \\
\mathrm{L}_{\mathrm{t}}=\mathrm{L}_{0}\left(1+8.71 \times 10^{-8} \Delta \mathrm{T}\right) & \text { Normal direction to rolling } \\
\mathrm{L}_{\mathrm{t}}=\mathrm{L}_{0}\left(1+6.58 \times 10^{-6} \Delta \mathrm{T}\right) & \text { Transverse direction to rolling }
\end{array}
$$

where $\quad \Delta \mathrm{T}=\mathrm{T}-30^{\circ} \mathrm{C}$.

The average and instantaneous coefficients of expansion for these data are identical; they are shown as a function of direction in Table 4 .

A typical curve of expansion versus temperature of a longitudinal specimen heated through the phase transformation region is shown in Figure 10. The behavior is somewhat unusual in that it shows a region during which the specimen remains constant in length as the temperature changes. The effect is not due to equipment lag, because a specimen of steel taken through its phase transformation showed the customary "hump" encountered in dilatometric curves. As a result of this plateau, three distinct breaks in the curve of expansion versus temperature are noted: the start of the plateau, the end, and the inflection point where the length again begins to increase. It is assumed that the first break is the initiation of the $\alpha \rightarrow \beta$ reaction, and the final one the completion. From an analysis of several dilatometric curves, which exhibited good data in the phase transformation regions, the temperatures for these reactions were established and are shown in Table 5.

Specimens heated through the phase transformation and cooled exhibited, in all cases, a small permanent deformation. This effect has

*A previous report on this phase of the investigation (R. L. Mehan and G. L. Cutler, "Thermal Expansion of Zircaloy-2 between Room Temperature and $1000^{\circ} \mathrm{C}$," KAPL-AL-RIM-15, May 16, 1958) and "Zirconium Highlights" (WAPD-ZH-9, July 1958) stated that no effect due to anistropy was found. Changes in the dilatometer since then have made the instrument more accurate and anisotropy effects, which formerly were attributed to data scattering, definitely were shown. The data reported previously are very similar to the transverse data in this report, except that in the present case a linear rather than a quadratic fit to the data has been used. 


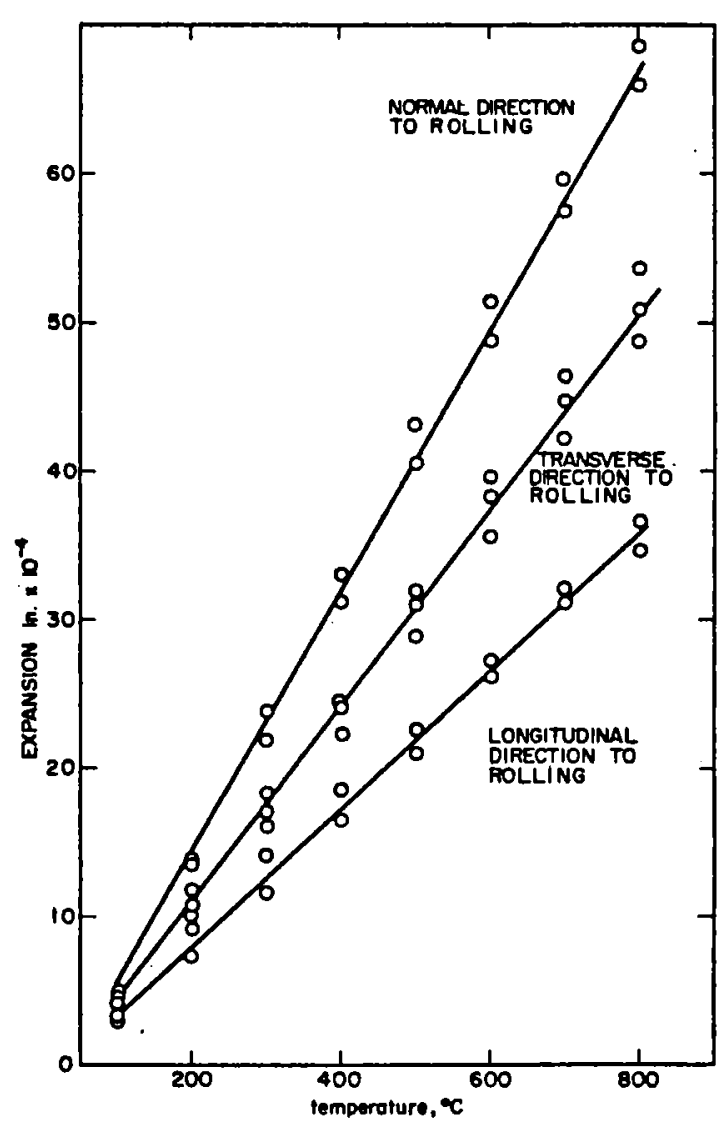

FIGURE 9. EXPANSION $Y$ S TEMPERATURE FOR ZIRCALOY -2 IN THE THREE PRINCIPAL DIRECTIONS TO ROLLING

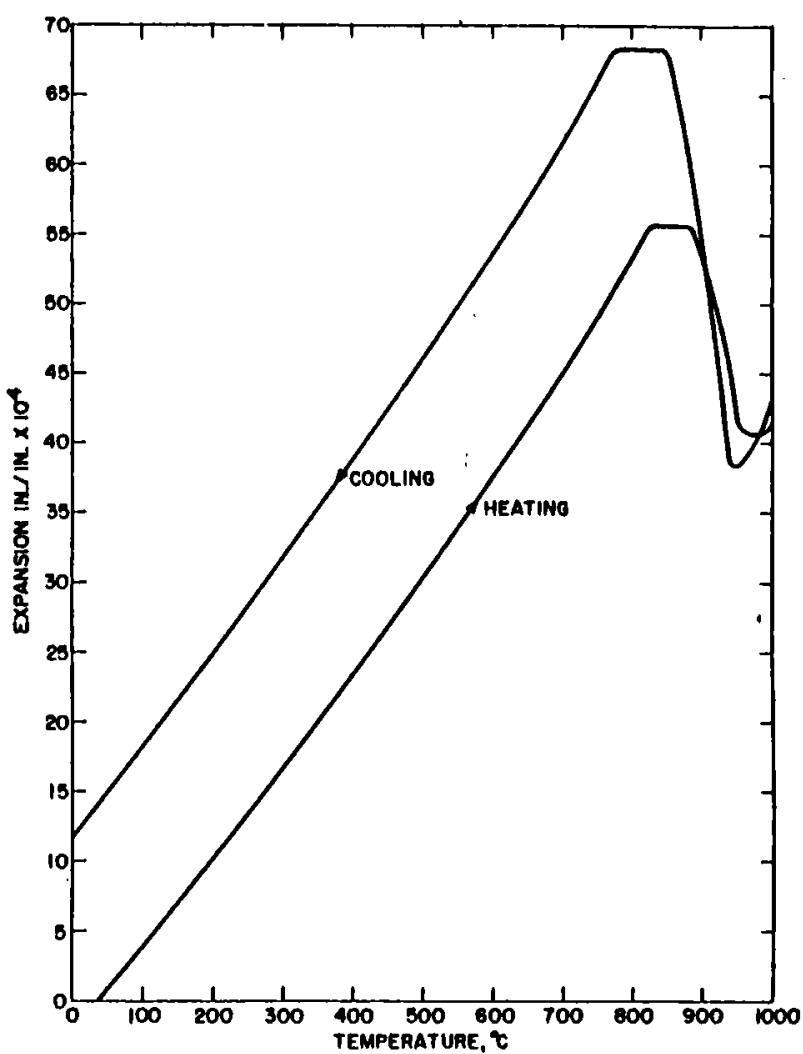

FIGURE 10. TYPICAL THERMAL DILATATION CURVE FOR ZIRCALOY-2 LONGITUDINAL TO THE ROLLING DIRECTION

TABIE 4. AVERAGE AND INSTANTANEOUS COBFFICIENT OF BXPANSION FOR ZIRGALOY-2

Between 25 and $800^{\circ} \mathrm{C}$ in the Three Princtpal Directions to Rolling

Direction to Rolling

Iong Itudinal

Transverse

Normal
Average or Instantaneous Coefficient of sxpansion, in./in. $/{ }^{\mathrm{F}}$
$4.62 \times 10^{-6}$
$6.58 \times 10^{-6}$
$8.71 \times 10^{-0}$

TABIE 5. TEMPERATURE FOR TRANSFORMATION IN ZIRGALOY-2 DIIATOMETRIC SPECIMENS

\begin{tabular}{l} 
Reaction \\
\hline Start $\alpha \rightarrow \beta \quad$ (first "break") \\
Finish $\alpha \rightarrow \beta$ (third "break") \\
Start $\beta \rightarrow \alpha$ (first "break") \\
(second "break") \\
Finish $\beta \rightarrow \alpha$ (third "break")
\end{tabular}

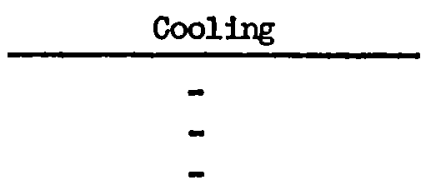

$942^{\circ} \mathrm{C} \pm 3\left(1728^{\circ} \mathrm{F} \pm 5\right)$

$854^{\circ} \mathrm{C} \pm 6\left(1569^{\circ} \mathrm{F} \pm 11\right)$

$783^{\circ} \mathrm{C} \pm 5\left(14410^{\circ} \mathrm{F} \pm 9\right)$ 
been noted before for zirconium and has been found to be highly directional. 9 For the present investigation, the changes in length, after approximately three cycles through the phase transformation, were:

\begin{tabular}{lc} 
Direction to Rolling & Change in Length, $\%$ \\
\hline Longitudinal & $+0.28 \pm 0.05$ \\
Transverse & $+0.26 \pm 0.14$ \\
Normal & $-0.71 \pm 0.30$
\end{tabular}

In addition to length changes, distortion of the cross section from circular to elliptical was observed. The ratio of the major axis to the original diameter was in the range of 0.4 to $1.4 \%$. As these values show, considerable scatter was obtained.

Modulus of Elasticity

The modulus of elasticity of Zircaloy-2 was determined at room and elevated temperature by dynamic techniques and was checked by static techniques. The dynamic modulus* was obtained by measuring the resonant frequency of the test specimen, shown in Figure 5, when supported as a free-free beam. Excitation was accomplished by striking the beam with an electromagnetic tapper. Frequency was measured by standard techniques and converted to modulus values by conventional methods. ${ }^{10}$ The entire apparatus was enclosed in a gas-tight box which had a small constant flow of argon through it. Static moduli at room temperature were obtained with Tuckerman gages, and the elevated temperature tests were performed with an OS Peters PS5M extensometer with extension arms. The results are shown in Figure 11. Only longitudinal values at elevated temperature were obtained. Excellent agreement between static and dynamic values at room temperature were obtained, and good agreement was obtained at $600 \%$. This agreement between static and dynamic values is to be expected on the basis of previous work reported by J. T. Richards. II

\section{Tensile Properties}

Tensile tests were performed in a 10,000-1b-capacity Instron testing machine with a cross-head speed of $0.02 \mathrm{in.} / \mathrm{min}$. The test specimen used is show in Figure 2. The values of $0.2 \%$ yield strength, ultimate tensile strength, and uniform plastic elongation** were obtained from the autographic record of the test, measured by an Instron machine as

\footnotetext{
*Dynamic modulus values were obtained at the General Electric Materials and Processes Laboratory of the Large Steam Turbine and Generator Division in Schenectady, New York.

**Uniform plastic elongation is defined as the strain at maximum load; neglecting elastic strains.
} 


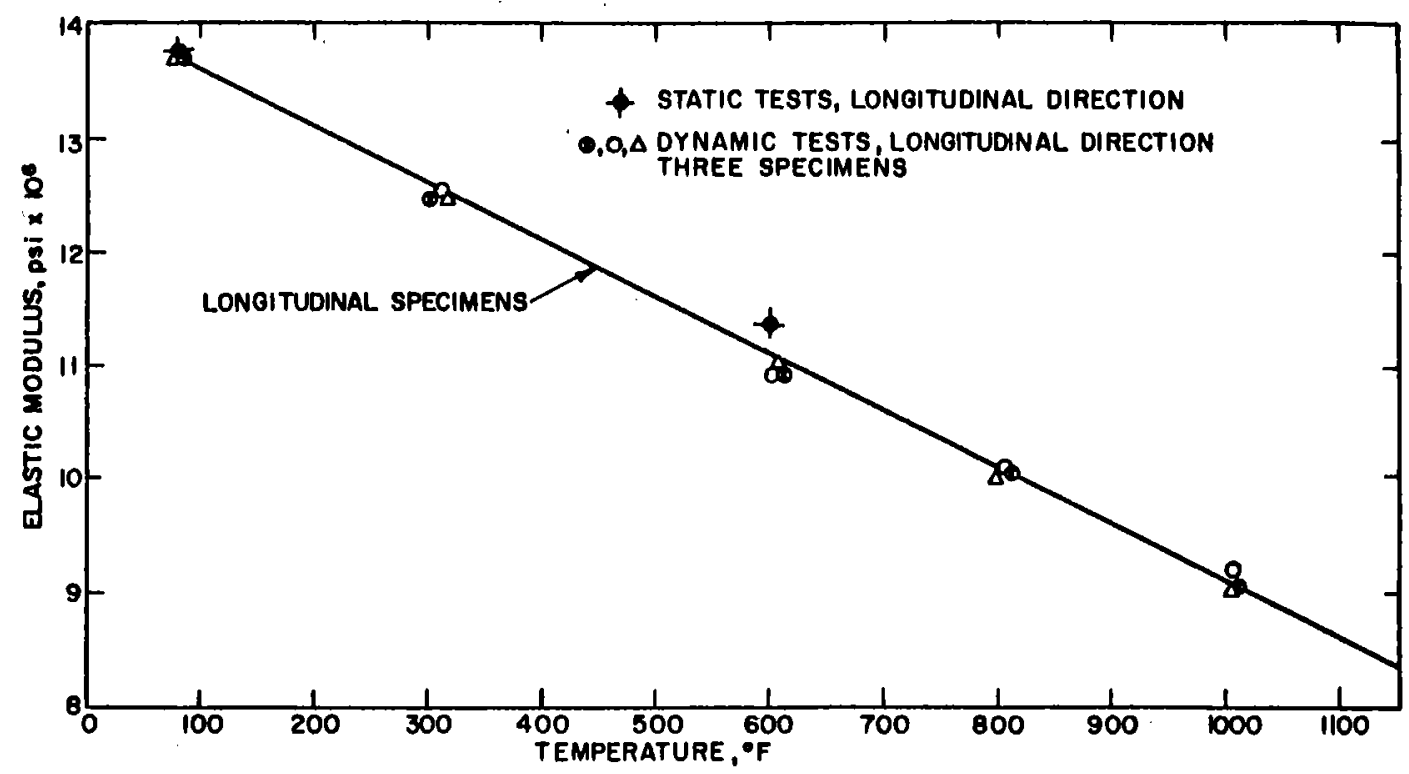

FIGURE 11. MODULUS OF ELASTICITY OF ZIRCALOY-2 $\checkmark$ TEMPERATURE

total cross-head movement versus load. The reduction in area and total elongation for the unnotched specimens were obtained by conventional techniques. An effective gage length of 1.1 in. was assumed for determination of yield strength and total elongation. The reduction in area of notched tensile specimens was obtained by careful measurements at 50 magnifications of the cross-sectional area after test with a filar eyepiece attached to a microscope.

All tests at elevated temperature were performed in an inert atmosphere, either of helium or argon. The furnace assembly was evacuated and purged twice before the specimen was brought to temperature. A small constant flow of inert gas was maintained during test. No attempt was made to purify the inert gas and, because of the lack of gas purity, as well as small leaks in the system, some oxidation occurred at the higher temperatures.

Approximately 124 tensile specimens were tested and the tensile properties were determined as a function of five variables: temperature, grain size, hydrogen content, directionality to rolling, and notch conditions (either smooth or notched). A summary of the specimen assignments with reference to these variables is shown in Table 6.

A complete listing of the test results is presented in Tables 7 and 8. The main trends of tensile properties as a function of the test variables are show in Figures 12 to 20 . These graphs are selfexplanatory, but the salient features are discussed below. 
TABLE 6. SPECIMEN ASSIGMMENIS FOR TENSIIE TESTS

Test Direction

\begin{tabular}{|c|c|c|c|c|c|c|c|c|}
\hline \multirow{4}{*}{$\begin{array}{c}\text { Teat } \\
\text { Temperature, } \\
0_{F} \\
\end{array}$} & \multirow{4}{*}{$\begin{array}{c}\text { Notoh } \\
\text { Condition }\end{array}$} & \multirow{4}{*}{$\begin{array}{l}\text { Grain } \\
\text { size }\end{array}$} & \\
\hline & & & \multicolumn{3}{|c|}{ Longitudinal } & \multicolumn{3}{|c|}{ Transverse } \\
\hline & & & Hydrogen & Content & $t, \mathrm{ppm}$ & Hydrogen & Content & $t, p p m$ \\
\hline & & & 12 & 150 & 500 & 12 & 150 & 500 \\
\hline \multirow{4}{*}{77} & \multirow{2}{*}{ Unnotched } & Normal & 2 & 2 & 2 & 2 & 2 & 2 \\
\hline & & Large & 2 & 2 & 2 & - & - & - \\
\hline & \multirow{2}{*}{ Notched } & Normal & 2 & 2 & 2 & 2 & 2 & 2 \\
\hline & & Large & 2 & 2 & 2 & - & - & - \\
\hline \multirow{4}{*}{300} & \multirow{2}{*}{ Unnotched } & Normal & 2 & 2 & 2 & 2 & 2 & 2 \\
\hline & & Large & - & - & - & - & - & - \\
\hline & \multirow{2}{*}{ Notched } & Normal & 2 & 2 & 2 & 2 & 2 & 2 \\
\hline & & Large & - & - & - & - & - & - \\
\hline \multirow{4}{*}{600} & \multirow{2}{*}{ Unnotched } & Normal & 2 & 2 & 2 & 2 & 2 & 2 \\
\hline & & Large & 2 & - & - & - & - & - \\
\hline & \multirow{2}{*}{ Notched } & Normal & 2 & 2 & 2 & 2 & 2 & 2 \\
\hline & & Large & 2 & - & - & - & - & - \\
\hline \multirow{4}{*}{800} & \multirow{2}{*}{ Unnotched } & Normal & 2 & 2 & 2 & 2 & 2 & 2 \\
\hline & & Large & - & - & - & - & - & - \\
\hline & \multirow{2}{*}{ Notched } & Normal & - & - & - & - & - & - \\
\hline & & Large & - & - & - & - & - & - \\
\hline \multirow{4}{*}{1000} & \multirow{2}{*}{ Unnotched } & Normal & 2 & 2 & 2 & 2 & 2 & 2 \\
\hline & & Large & 2 & - & - & $\overline{-}$ & - & - \\
\hline & \multirow{2}{*}{ Notched } & Normal' & 2 & - & - & 2 & - & - \\
\hline & & Large & 2 & - & - & - & - & - \\
\hline \multirow{6}{*}{1100} & \multirow{2}{*}{ Unnotched } & Normal & 2 & - & - & 2 & - & - \\
\hline & & Iarge & - & - & - & - & - & - \\
\hline & \multirow{4}{*}{ Notched } & Normal & - & - & - & - & - & - \\
\hline & & Large & - & - & - & $=$ & - & $m$ \\
\hline & & Subtotal & 32 & 20 & 20 & 20 & 16 & 16 \\
\hline & & Total & & 72 & & & 52 & \\
\hline
\end{tabular}

1. Both the yield strength and the ultimate tensile strength decrease rapidly with increasing temperature (see Figures 12, 13, and 16). A plateau is evident in the neighborhood of $600^{\circ} \mathrm{F}$, which is more pronounced in the longitudinal direction. Around $600^{\circ} \mathrm{F}$, ductility increases rapidly as a function of temperature, again with a slight "hesitation" in the longitudinal direction (see Figures 14 and 16).

2. There is a pronounced effect of directionality on both strength and ductility (Figure 16). The transverse direction exhibits a higher yield strength, higher ductility (up to $800 \%$ ), and a lower ultimate strength than does the longitudinal direction. This implies that the strain 
hardening exponent* is lower in the transverse direction. This can be verified by inspecting the values of the plastic uniform elongation in Tables 7 and 8. This quantity, expressed as a true strain, is numerically equal to the strain-hardening exponent.12 The effect of directionality can also be seen in the ellipticality of the cross-sectional area of the tensile specimen after failure. The data are show in Figure 19.

3. The effect of grain size on tensile properties is minor (Figures 10, 11, and 12). A slight decrease in both the strength and ductility is noted.

4. The notch strength and ductility behavior is as expected for a notch-insensitive material (Figures 13 and 15). The notch strength ratio ${ }^{* *}$ is in the order of 1.47 at room temperature and the notch ductility is above $10 \%$ in the absence of hydrogen.

5. The effect of hydrogen varies considerably, depending on the material conditions. Hydrogen up to $500 \mathrm{ppm}$ has a moderate strengthening effect on unnotched specimens with both fine and coarse grains, irrespective of direction to rolling. The unnotched ductility may be reduced by as much as $50 \%$, but in no case is it reduced to a value less than $0.18 \mathrm{in./in.} \mathrm{strain} \mathrm{(expressed} \mathrm{as} \mathrm{reduction} \mathrm{in} \mathrm{area).}$ The effects of hydrogen decrease with increasing test temperature.

The effect of hydrogen on notched properties varies with grain size (Figure 13). Hardly any effect on the notch strength is found for finegrained material, but the combination of large grains and 500-ppm hydrogen results in a sizable reduction in the notch strength. In fact, the notch strength falls below the unnotched strength. The notch ductility is reduced by hydrogen for both fine- and coarse-grained material, but in no case falls below 0.06 in./in. strain.

*The strain hardening exponent, $m$, is defined as

$$
\mathrm{m}=\left(\frac{\partial \log \sigma}{\partial \log \epsilon_{\mathrm{p}}}\right)_{\mathrm{T}, \dot{\epsilon}}
$$

where $\quad \sigma=$ true stress

$\epsilon_{\mathrm{p}}=$ true plastic strain

$\hat{\epsilon}=$ true strain rate

$\mathrm{T}=$ temperature

* Notch strength ratio is defined as the ratio of notched to unnotched nominal ultimate tensile strengths. 
TABLE 7. RESULTS OF TENSIIE TESTS OF ANNEALED ZIRCALOY-2 IN THE LONGITUDINAL DIRECTION

\begin{tabular}{|c|c|c|c|c|c|c|c|c|}
\hline $\begin{array}{c}\text { Specimen } \\
\text { No. } \\
\end{array}$ & $\begin{array}{c}\text { Test } \\
\text { Temperature, } \\
\mathrm{o}_{\mathrm{F}} \\
\end{array}$ & $\begin{array}{c}\mathrm{H}_{2} \\
\text { Content, } \\
\text { ppm } \\
\end{array}$ & $\begin{array}{l}0.2 \% \text { YS, } \\
\text { psi } \times 10^{3} \\
\end{array}$ & $\begin{array}{c}\text { UTS, } \\
\text { psi } \times 10^{3} \\
\end{array}$ & $\begin{array}{c}\text { Total } \\
\text { Elongation } \\
\text { in } 1.1 \text { in., } \\
\% \\
\end{array}$ & $\begin{array}{c}\text { Uniform } \\
\text { Elongation } \\
\text { in } 1.1 \text { in., } \\
\%\end{array}$ & $\begin{array}{c}\text { Reduction } \\
\text { of Area, } \\
\% \\
\end{array}$ & $\begin{array}{c}\text { Fracture } \\
\text { Stress } \\
\text { psi } \times 10^{3} \\
\end{array}$ \\
\hline \multicolumn{9}{|c|}{ Unnotched, Normal Grain Size } \\
\hline $\begin{array}{l}\mathrm{L} 10-1 \\
\mathrm{~L} 5-1\end{array}$ & $\begin{array}{l}77 \\
77\end{array}$ & $\begin{array}{l}12 \\
12\end{array}$ & $41.842 .6^{*}$ & $\begin{array}{l}70.1 \\
70.4\end{array} 70.3^{*}$ & $\begin{array}{l}27.6 \\
26.3^{27.0^{*}}\end{array}$ & $\begin{array}{l}15.9 \\
15.2\end{array}$ & $\begin{array}{l}47.8 \\
45.2^{46.2^{*}}\end{array}$ & $\begin{array}{l}108.6120 .8^{*} \\
133.1\end{array}$ \\
\hline $\begin{array}{l}L 7-1 \\
\text { L2-1 }\end{array}$ & $\begin{array}{l}300 \\
300\end{array}$ & $\begin{array}{l}12 \\
12\end{array}$ & $\begin{array}{l}30.6 \\
30.4\end{array} 30.5^{*}$ & $\begin{array}{l}49.4 \\
48.8\end{array} 49.1^{*}$ & $\begin{array}{l}25.4 \\
29.0\end{array} 27.2^{*}$ & $\frac{14.4}{17.7} 16.1^{*}$ & $\begin{array}{l}48.3 \\
57.2\end{array} 52.8^{*}$ & $\begin{array}{l}76.0 \\
75.0\end{array} 75.5^{*}$ \\
\hline L7-2工 & 400 & 12 & 24.0 & 40.2 & 34.7 & 17.9 & 64.0 & 83.7 \\
\hline L8-22 & 500 & 12 & 20.5 & 35.5 & 27.3 & 13.0 & 71.3 & 89.8 \\
\hline $\begin{array}{l}\mathrm{L}_{4}-1 \\
\mathrm{~L}_{3}-1\end{array}$ & $\begin{array}{l}600 \\
600\end{array}$ & $\begin{array}{l}12 \\
12\end{array}$ & $\begin{array}{l}17.5 \\
15.7 \\
16.6^{*}\end{array}$ & $\begin{array}{l}31.9 \\
31.4\end{array} 31.7^{*}$ & $\begin{array}{l}31.8 \\
31.9\end{array} 31.9^{*}$ & $\begin{array}{l}20.8 \\
19.6\end{array} 20.2^{*}$ & $\begin{array}{l}55.5 \\
74.6\end{array} 65.1^{*}$ & $\begin{array}{l}48.3 \\
80.0\end{array} 64.2^{*}$ \\
\hline L8-21 & 700 & 12 & 15.8 & 29.4 & 29.3 & 16.5 & 80.0 & 82.9 \\
\hline $\begin{array}{l}\text { L6-1 } \\
\text { L10-2 }\end{array}$ & $\begin{array}{l}800 \\
800\end{array}$ & $\begin{array}{l}12 \\
12\end{array}$ & $\begin{array}{l}17.316 .2^{*} \\
15.1\end{array}$ & $\frac{29.0}{28.0} 28.5^{*}$ & $\begin{array}{l}25.1 \\
27.3 \\
26.2^{*}\end{array}$ & ${ }^{-} 16.0^{16.0^{*}}$ & 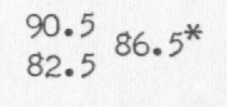 & $\begin{array}{l}87.285 .8^{*} \\
84.3\end{array}$ \\
\hline $\begin{array}{l}\mathrm{L} 7-2 \\
\mathrm{~L} 2-2\end{array}$ & $\begin{array}{l}1000 \\
1000\end{array}$ & $\begin{array}{l}12 \\
12\end{array}$ & $\begin{array}{l}11.9 \\
11.9 \\
11.9^{*}\end{array}$ & $\begin{array}{l}19.8 \\
18.2 \\
19.0^{*}\end{array}$ & $\begin{array}{l}38.1 \\
51.845 .0^{*}\end{array}$ & $\begin{array}{l}12.5 \\
14.5 \\
13.5^{*}\end{array}$ & $\begin{array}{l}86.6 \\
89.6 .1^{*}\end{array}$ & $\begin{array}{l}48.2 \\
66.6^{57.4^{*}}\end{array}$ \\
\hline $\begin{array}{l}\mathrm{L} 3-2 \\
\mathrm{~L} 10-3\end{array}$ & $\begin{array}{l}1100 \\
1100\end{array}$ & $\begin{array}{l}12 \\
12\end{array}$ & $\begin{array}{l}9.1 \\
7.6\end{array} 8.4^{*}$ & $\frac{11.7}{10.4} 11.1^{*}$ & 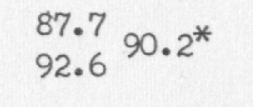 & $\begin{array}{l}17.718 .4^{*} \\
19.1\end{array}$ & $\begin{array}{l}94.0 \\
97.0\end{array} 95.5^{*}$ & $\begin{array}{l}33.358 .2^{*} \\
83.0\end{array}$ \\
\hline $\begin{array}{l}\text { L5-2 } \\
\text { L6-2 }\end{array}$ & $\begin{array}{l}77 \\
77\end{array}$ & $\begin{array}{l}150 \\
150\end{array}$ & $\begin{array}{l}46.7 \\
45.8\end{array} 46.3^{*}$ & $70.671 .1^{*}$ & $\begin{array}{l}25.6 \\
20.5\end{array}$ & 14.6 & \multicolumn{2}{|c|}{$\begin{array}{l}47.2 \\
44.8\end{array} 46.1^{*}{ }_{114.1} 111.712 .9^{*}$} \\
\hline $\begin{array}{l}\mathrm{L} 5-3 \\
\mathrm{~L} 3-3\end{array}$ & $\begin{array}{l}300 \\
300\end{array}$ & $\begin{array}{l}150 \\
150\end{array}$ & $\begin{array}{l}34.6 \\
32.3\end{array} 33.5^{*}$ & $\begin{array}{l}49.5 \\
47.3\end{array} 48.4^{*}$ & $\begin{array}{l}25.4 \\
30.3\end{array} 27.9^{*}$ & $\begin{array}{l}16.0 \\
19.7 \\
17.9^{*}\end{array}$ & $\begin{array}{l}51.8 \\
53.2\end{array} 52.5^{*}$ & $\begin{array}{l}86.5 \\
84.0\end{array} 85.3^{*}$ \\
\hline $\begin{array}{l}\mathrm{L} 10-4 \\
\mathrm{~L} 9-\end{array}$ & $\begin{array}{l}600 \\
600\end{array}$ & $\begin{array}{l}150 \\
150\end{array}$ & $\begin{array}{l}15.9 \\
15.6 \\
\end{array}$ & $\begin{array}{l}30.9 \\
30.4\end{array} 30.7^{*}$ & 28.3 & $\begin{array}{l}23.8 \\
18.5^{21 .} 2^{*}\end{array}$ & $\begin{array}{l}79.6 \\
78.2\end{array} 78.9^{*}$ & $\begin{array}{l}87.8 \\
80.4\end{array} 84.1^{*}$ \\
\hline $\begin{array}{l}\text { L7-3 } \\
\text { L9-2 }\end{array}$ & $\begin{array}{l}800 \\
800\end{array}$ & $\begin{array}{l}150 \\
150\end{array}$ & $\begin{array}{l}14.7 \\
17.7\end{array}$ & $\begin{array}{l}25.6 \\
27.4\end{array} 26.5^{*}$ & $\begin{array}{l}24.1 \\
26.4\end{array} 25.3^{*}$ & $\begin{array}{l}12.3 \\
12.7\end{array} 12.5^{*}$ & $\begin{array}{l}83.1 \\
82.6^{82.9^{*}}\end{array}$ & $65.968 .3^{*}$ \\
\hline $\begin{array}{l}\mathrm{L} 5-4 \\
\mathrm{~L} 4-2\end{array}$ & $\begin{array}{l}1000 \\
1000\end{array}$ & $\begin{array}{l}150 \\
150\end{array}$ & $\begin{array}{l}12.2 \\
11.9\end{array} 12.1^{*}$ & $\begin{array}{l}16.8 \\
16.7\end{array} 16.8^{*}$ & $\begin{array}{l}52.4 \\
52.2^{5.3^{*}}\end{array}$ & $\begin{array}{l}16.5 \\
20.3 \\
18.4^{*}\end{array}$ & $\begin{array}{l}95.0 \\
88.1\end{array} 91.6^{*}$ & $\begin{array}{l}22.0 \\
56.3\end{array} 39.2^{*}$ \\
\hline $\begin{array}{l}\mathrm{L} 9-5 \\
\mathrm{~L} 10-6\end{array}$ & $\begin{array}{l}77 \\
77\end{array}$ & $\begin{array}{l}500 \\
500\end{array}$ & $\begin{array}{l}49.2 \\
48.348 .8^{*}\end{array}$ & $\begin{array}{l}70.671 .2^{*} \\
71.8\end{array}$ & $\begin{array}{l}15.1 \\
12.814 .0^{*}\end{array}$ & $11.811 .4^{*}$ & $\begin{array}{l}20.1 \\
18.8\end{array}$ & $\begin{array}{l}83.6 \\
83.5\end{array} 83.6^{*}$ \\
\hline $\begin{array}{l}\mathrm{L} 10-7 \\
\mathrm{~L} 2-10\end{array}$ & $\begin{array}{l}300 \\
300\end{array}$ & $\begin{array}{l}500 \\
500\end{array}$ & $\begin{array}{l}34.9 \\
34.9\end{array} 34.9^{*}$ & $\begin{array}{l}52.0 \\
51.8 \\
51.9^{*}\end{array}$ & $\begin{array}{l}19.9 \\
28.0\end{array} 24.0^{*}$ & $\begin{array}{l}14.1 \\
18.4 \\
16.3^{*}\end{array}$ & $\begin{array}{l}39.2 \\
44.7 \\
42.0^{*}\end{array}$ & $\begin{array}{l}79.3 \\
79.1\end{array} 79.2^{*}$ \\
\hline $\begin{array}{l}\text { I6-13 } \\
\text { L5-9 }\end{array}$ & $\begin{array}{l}600 \\
600\end{array}$ & $\begin{array}{l}500 \\
500\end{array}$ & $\begin{array}{l}22.6 \\
20.0\end{array} 21.3^{*}$ & $\begin{array}{l}32.8 \\
32.0 \\
32.4^{*}\end{array}$ & $\begin{array}{l}28.4 \\
30.6 \\
29.5^{*}\end{array}$ & $\begin{array}{l}15.5 \\
14.5 \\
15.0^{*}\end{array}$ & $\begin{array}{l}74.1 \\
74.8\end{array} 74.4^{*}$ & $\begin{array}{l}79.8 \\
74.5\end{array} 77.2^{*}$ \\
\hline $\begin{array}{l}\mathrm{L} 5-10 \\
\mathrm{~L} 8-2\end{array}$ & $\begin{array}{l}800 \\
800\end{array}$ & $\begin{array}{l}500 \\
500\end{array}$ & $\begin{array}{l}20.3 \\
18.4\end{array} 19.4^{*}$ & $\begin{array}{l}28.0 \\
27.3\end{array} 27.7^{*}$ & $\begin{array}{l}25.0 \\
23.7\end{array} 24.4^{*}$ & $\frac{11.5}{10.3} 10.9^{*}$ & $\begin{array}{l}83.7 \\
83.5 \\
83.6^{*}\end{array}$ & $\begin{array}{l}75.7 \\
72.7\end{array} 73.7^{*}$ \\
\hline $\begin{array}{l}\text { I7-9 } \\
\text { II- }-3\end{array}$ & $\begin{array}{l}1000 \\
1000\end{array}$ & $\begin{array}{l}500 \\
500\end{array}$ & $\begin{array}{r}9.7 \\
12.7 \\
11.2^{*}\end{array}$ & $=\frac{11.9}{14.8} 13.4^{*}$ & $\begin{array}{l}63.0 \\
46.1\end{array} 54.6^{*}$ & ${ }_{-}^{13.8} 13.8^{*}$ & $\begin{array}{l}92.5 \\
89.6\end{array} 91.1^{*}$ & $\begin{array}{l}40.0 \\
61.9\end{array} 52.0^{*}$ \\
\hline \multicolumn{9}{|c|}{ Unnotched, Large Grain Size } \\
\hline $\begin{array}{l}\mathrm{L1} 0-14 \\
\mathrm{~L} 9-14\end{array}$ & $\begin{array}{l}77 \\
77\end{array}$ & $\begin{array}{l}12 \\
12\end{array}$ & $\frac{40.4}{40.4} 40.4^{*}$ & $\begin{array}{l}66.2 \\
65.2\end{array} 65.7^{*}$ & $\begin{array}{l}21.6 \\
18.3\end{array} 20.0^{*}$ & $\begin{array}{l}13.7 \\
13.5\end{array} 13.6^{*}$ & $\begin{array}{l}40.9 \\
36.9\end{array} 38.9^{*}$ & $\begin{array}{l}95.7 \\
89.6\end{array} 92.7^{*}$ \\
\hline $\begin{array}{l}\text { L8-12 } \\
\text { L2-19 }\end{array}$ & $\begin{array}{l}600 \\
600\end{array}$ & $\begin{array}{l}12 \\
12\end{array}$ & $\begin{array}{l}16.9 \\
17.1 \\
17.0^{*}\end{array}$ & $\frac{28.0}{28.4} 28.2^{*}$ & $\begin{array}{l}31.5 \\
38.1\end{array} 34.8^{*}$ & $\begin{array}{l}17.8 \\
18.7 \\
18.3^{*}\end{array}$ & 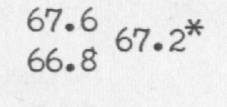 & $\begin{array}{l}56.3 \\
58.7\end{array} 57.5^{*}$ \\
\hline $\begin{array}{l}\mathrm{L} 1-15 \\
\mathrm{~L} 3-18\end{array}$ & $\begin{array}{l}1000 \\
1000\end{array}$ & $\begin{array}{l}12 \\
12\end{array}$ & 14.7 14.6 $14.7^{*}$ & $\begin{array}{l}20.4 \\
19.5\end{array} 20.0^{*}$ & $\begin{array}{l}24.3 \\
24.2\end{array} 24.2^{*}$ & $\begin{array}{l}7.8 \\
8.0\end{array} 7.9^{*}$ & $\begin{array}{l}83.6 \\
84.0\end{array} 83.8^{*}$ & $=\begin{array}{l}59.7 \\
56.3\end{array} 58.0^{*}$ \\
\hline $\begin{array}{l}\mathrm{L1} 10-12 \\
\mathrm{~L} 3-17\end{array}$ & $\begin{array}{l}77 \\
77\end{array}$ & $\begin{array}{l}150 \\
150\end{array}$ & $\begin{array}{l}40.9 \\
43.9 \\
42.4^{*}\end{array}$ & 64.8 65.7 $65.3^{*}$ & $\begin{array}{l}16.7 \\
17.4\end{array}$ & ${ }_{11.9}^{11.9} 11.7^{*}$ & $\begin{array}{l}26.3 \\
23.7 \\
25.0^{*}\end{array}$ & $\begin{array}{l}82.8 \\
79.5\end{array} 81.2^{*}$ \\
\hline $\begin{array}{l}L 8-11 \\
L 6-17\end{array}$ & $\begin{array}{l}77 \\
77\end{array}$ & $\begin{array}{l}500 \\
500\end{array}$ & $\begin{array}{l}43.9 \\
46.5\end{array} 45.2^{*}$ & ${ }^{65.9} 66.964^{*}$ & $\begin{array}{l}12.4 \\
10.7\end{array} 11.5^{*}$ & ${ }^{10.4} 10.5^{*}$ & $\begin{array}{l}18.2 \\
19.2\end{array} 18.7^{*}$ & $\begin{array}{r}97.6 \\
101.1\end{array} 99.4^{*}$ \\
\hline \multicolumn{9}{|c|}{ Notched, Normal Grain Size } \\
\hline $\begin{array}{l}\text { L7-10 } \\
\mathrm{L} 3-14\end{array}$ & $\begin{array}{l}77 \\
77\end{array}$ & $\begin{array}{l}12 \\
12\end{array}$ & - & $\begin{array}{l}100.0 \\
100.0 \\
100.0^{*}\end{array}$ & $=$ & - & $\begin{array}{l}13.9 \\
15.7\end{array} 14.8^{*}$ & ${ }^{*} \frac{111.8}{112.0} 111.9^{*}$ \\
\hline $\begin{array}{l}\mathrm{L} 4-7 \\
\mathrm{~L}-7-9\end{array}$ & $\begin{array}{l}300 \\
300\end{array}$ & $\begin{array}{l}12 \\
12\end{array}$ & - & $\begin{array}{l}73.9 \\
75.2\end{array} 74.6^{*}$ & - & - & $\frac{21.3}{22.0} 21.7 *$ & $\begin{array}{l}87.7 \\
78.8\end{array} 83.3 *$ \\
\hline $\begin{array}{l}\text { I7-11 } \\
\text { I-10-8 }\end{array}$ & $\begin{array}{l}600 \\
600\end{array}$ & $\begin{array}{l}12 \\
12\end{array}$ & - & $\begin{array}{l}51.9 \\
50.5\end{array} 51.2^{*}$ & $\overline{-}$ & - & $41.641 .5^{*}$ & ${ }_{48.4}^{52.4} 50.4^{*}$ \\
\hline $\begin{array}{l}\text { L9-9 } \\
\text { L8-6 }\end{array}$ & $\begin{array}{l}1000 \\
1000\end{array}$ & $\begin{array}{l}12 \\
12\end{array}$ & - & $\begin{array}{l}30.9 \\
32.1\end{array} 1.5^{*}$ & - & - & - & - \\
\hline $\begin{array}{l}\mathrm{L} 8-24 \\
\mathrm{~L} 3-15\end{array}$ & $\begin{array}{l}77 \\
77\end{array}$ & $\begin{array}{l}150 \\
150\end{array}$ & - & $\begin{array}{r}92.3 \\
105.0\end{array} 98.7^{*}$ & - & $\overline{-}$ & $\begin{array}{r}14.4 \\
8.2 \\
11.3^{*}\end{array}$ & $\begin{array}{l}107.9 \\
104.8\end{array} 106.4^{*}$ \\
\hline $\begin{array}{l}16-14 \\
\mathrm{~L} 4-8\end{array}$ & $\begin{array}{l}300 \\
300\end{array}$ & $\begin{array}{l}150 \\
150\end{array}$ & - & 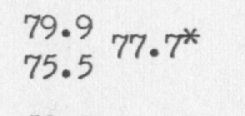 & - & - & $\begin{array}{l}10.8 \\
19.6\end{array}$ & $\begin{array}{l}79.1 \\
82.9\end{array} 81.0^{*}$ \\
\hline $\begin{array}{l}\mathrm{L} 7-10 \\
\mathrm{~L} 8-23\end{array}$ & $\begin{array}{l}600 \\
600\end{array}$ & $\begin{array}{l}150 \\
150\end{array}$ & - & $\begin{array}{l}50.2 \\
50.0\end{array} 50.1^{*}$ & - & - & $\begin{array}{l}33.7 \\
20.6\end{array} 27.2^{*}$ & ${ }^{*} \begin{array}{l}36.2 \\
34.6\end{array} 35.4^{*}$ \\
\hline $\begin{array}{l}\text { II-11 } \\
\text { I-1-12 }\end{array}$ & $\begin{array}{l}77 \\
77\end{array}$ & $\begin{array}{l}500 \\
500\end{array}$ & - & $\begin{array}{l}99.0 \\
97.2\end{array} 98.1^{*}$ & - & - & $6.56 .7^{*}$ & $\begin{array}{l}106.0 \\
104.0\end{array}$ \\
\hline $\begin{array}{l}\text { L9-10 } \\
\text { I8-7 }\end{array}$ & $\begin{array}{l}300 \\
300\end{array}$ & $\begin{array}{l}500 \\
500\end{array}$ & - & $\begin{array}{l}77.0 \\
78.3\end{array} 77.7^{*}$ & - & - & $\frac{13.0}{9.4} 11.2^{*}$ & ${ }^{*} 84.083 .7^{*}$ \\
\hline $\begin{array}{l}\text { I.1-13 } \\
\text { L7-12 }\end{array}$ & $\begin{array}{l}600 \\
600\end{array}$ & $\begin{array}{l}500 \\
500\end{array}$ & - & 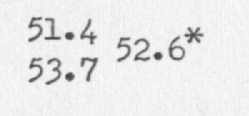 & - & $\overline{-}$ & 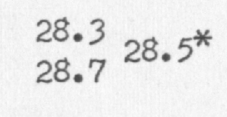 & $\begin{array}{l}* 36.8 \\
42.9\end{array} 39.9^{*}$ \\
\hline \multicolumn{9}{|c|}{ Notched, Large Grain Size } \\
\hline $\begin{array}{l}\text { L7- } 16 \\
\mathrm{~L} 8-13\end{array}$ & $\begin{array}{l}77 \\
77\end{array}$ & $\begin{array}{l}12 \\
12\end{array}$ & - & $\begin{array}{l}91.9 \\
91.3\end{array} 91.6^{*}$ & - & $\overline{-}$ & $12.612 .3^{*}$ & * $99.0^{-} 99.0^{*}$ \\
\hline $\begin{array}{l}\text { LL-18 } \\
\text { LI-17 }\end{array}$ & $\begin{array}{l}600 \\
600\end{array}$ & $\begin{array}{l}12 \\
12\end{array}$ & - & $42.943 .8^{*}$ & $\overline{-}$ & - & - & - \\
\hline $\begin{array}{l}\mathrm{L} 20-13 \\
\mathrm{~L} 0-15\end{array}$ & $\begin{array}{l}1000 \\
1000\end{array}$ & $\begin{array}{l}12 \\
12\end{array}$ & - & $\begin{array}{l}31.4 \\
33.3\end{array} 32.4^{*}$ & $\overline{-}$ & - & - & - \\
\hline $\begin{array}{l}\mathrm{L} 2-20 \\
\mathrm{~L} 5-16\end{array}$ & $\begin{array}{l}77 \\
77\end{array}$ & $\begin{array}{l}150 \\
150\end{array}$ & - & $\begin{array}{l}77.9 \\
81.7\end{array} 79.8^{*}$ & - & - & $\begin{array}{l}20.2 \\
19.3 \\
19.8^{*}\end{array}$ & $\begin{array}{r}97.6 \\
101.199 .4^{*}\end{array}$ \\
\hline $\begin{array}{l}\text { LI-16 } \\
\text { L } 4-17\end{array}$ & $\begin{array}{l}77 \\
77\end{array}$ & $\begin{array}{l}500 \\
500\end{array}$ & - & $\begin{array}{l}49.1 \\
62.755 .9^{*}\end{array}$ & - & - & $\begin{array}{l}13.212 .0^{*} \\
10.8\end{array}$ & $\begin{array}{l}* \begin{array}{l}56.5 \\
70.3\end{array} 63.4^{*}\end{array}$ \\
\hline
\end{tabular}


TABIE 8. RESULTS OF TENSIIE TESTS OF ANNEALED ZIRCALOY-2 IN THE TRANSVERSE DIRECTION

\begin{tabular}{|c|c|c|c|c|c|c|c|c|}
\hline $\begin{array}{l}\text { Specimen } \\
\text { No. } \\
\end{array}$ & $\begin{array}{c}\text { Test } \\
\text { Temperature, } \\
\mathrm{o}_{\mathrm{F}} \\
\end{array}$ & $\begin{array}{c}\mathrm{H}_{2} \\
\text { Content, } \\
\text { ppm } \\
\end{array}$ & $\begin{array}{l}0.2 \% \mathrm{YS}, \\
\mathrm{psi} \times 10^{3} \\
\end{array}$ & $\begin{array}{l}\text { UTS, } \\
\text { psi } \times 10^{3} \\
\end{array}$ & $\begin{array}{c}\text { Total } \\
\text { Elongation } \\
\text { in } 1.1 \text { in., } \\
\%\end{array}$ & $\begin{array}{l}\text { Uniform } \\
\text { Elongation } \\
\text { in } 1.1 \text { in., } \\
\%\end{array}$ & $\begin{array}{c}\text { Reduction } \\
\text { of Area, } \\
\%\end{array}$ & $\begin{array}{l}\text { Fracture } \\
\text { Stress } \\
\text { psi } \times 10^{3}\end{array}$ \\
\hline \multicolumn{9}{|c|}{ Unnotched, Normal Grain Size } \\
\hline $\begin{array}{l}\text { T7-1 } \\
\text { T2-1 }\end{array}$ & $\begin{array}{l}77 \\
77\end{array}$ & $\begin{array}{l}12 \\
12\end{array}$ & $\begin{array}{l}58.7 \\
59.8 \\
59.3^{*}\end{array}$ & $\begin{array}{l}65.2 \\
66.5 \\
65.9^{*}\end{array}$ & $\begin{array}{l}22.8 \\
26.5 \\
24.7^{*}\end{array}$ & $\begin{array}{l}10.111 .1^{*} \\
12.1\end{array}$ & $\begin{array}{l}60.7 \\
56.5\end{array} 58.6^{*}$ & $\begin{array}{l}129.0 \\
109.0\end{array} 119.0^{*}$ \\
\hline $\begin{array}{l}\mathrm{T} 1-1 \\
\mathrm{~T} 1-2\end{array}$ & $\begin{array}{l}300 \\
300\end{array}$ & $\begin{array}{l}12 \\
12\end{array}$ & $\begin{array}{l}36.3 \\
37.1\end{array} 36.7^{*}$ & $\begin{array}{l}42.5 \\
43.342 .9^{*}\end{array}$ & $39.339 .3^{*}$ & $\begin{array}{l}24.1 \\
22.9 \\
23.5^{*}\end{array}$ & $\begin{array}{l}64.2 \\
64 \cdot 2\end{array} 64 \cdot 2^{*}$ & $\begin{array}{l}94.4 \\
95.8\end{array} 95.1^{*}$ \\
\hline $\begin{array}{l}T 5-1 \\
T 6-3\end{array}$ & $\begin{array}{l}600 \\
600\end{array}$ & $\begin{array}{l}12 \\
12\end{array}$ & ${ }_{21.0}^{19.8} 20.4^{*}$ & $\begin{array}{l}26.5 \\
27.8 \\
27.2^{*}\end{array}$ & $\begin{array}{l}27.8 \\
36.7\end{array} 32.3^{*}$ & $\begin{array}{l}14.0 \\
15.1\end{array} 14.6^{*}$ & $\begin{array}{l}80.5 \\
79.0\end{array} 79.8^{*}$ & ${ }^{85.9} 85.9^{*}$ \\
\hline $\begin{array}{l}\text { T7-6 } \\
\text { T6-5 }\end{array}$ & $\begin{array}{l}800 \\
800\end{array}$ & $\begin{array}{l}12 \\
12\end{array}$ & $\begin{array}{l}15.8 \\
18.0 \\
16.9^{*}\end{array}$ & $\begin{array}{l}21.0 \\
24.4 \\
22.7^{*}\end{array}$ & $\begin{array}{l}17.5 \\
20.4\end{array} 19.0^{*}$ & $6.6^{6.4^{*}}$ & $\begin{array}{l}82.7 \\
85.5\end{array} 84.1^{*}$ & $\begin{array}{l}58.60 \\
56.40 \\
57.5^{*}\end{array}$ \\
\hline $\begin{array}{l}\text { T3-1 } \\
\text { T6-6 }\end{array}$ & $\begin{array}{l}1000 \\
1000\end{array}$ & $\begin{array}{l}12 \\
12\end{array}$ & $\begin{array}{l}13.4 \\
14.0 \\
13.7^{*}\end{array}$ & $\begin{array}{l}16.6 \\
16.9 \\
16.8^{*}\end{array}$ & $\begin{array}{l}45.0 \\
33.6\end{array} 39.3^{*}$ & $\begin{array}{l}7.2 \\
9.5 \\
\end{array}$ & $\begin{array}{l}84.2 \\
90.0 \\
87.1^{*}\end{array}$ & $\begin{array}{l}40.6 \\
60.0^{50.3^{*}}\end{array}$ \\
\hline $\begin{array}{l}\text { T1-3 } \\
\text { T6-8 }\end{array}$ & $\begin{array}{l}1100 \\
1100\end{array}$ & $\begin{array}{l}12 \\
12\end{array}$ & ${ }_{9.2}^{9.5} 9.4^{*}$ & $\begin{array}{l}11.0 \\
10.3 \\
10.7^{*}\end{array}$ & $\begin{array}{l}47.9 \\
63.4\end{array} 55.7^{*}$ & $\begin{array}{l}7.4 \\
2.9\end{array} 5.2^{*}$ & $\begin{array}{l}93.0 \\
94.0\end{array} 93.5^{*}$ & $\begin{array}{l}68.0 \\
33.3\end{array} 50.7^{*}$ \\
\hline $\begin{array}{l}\text { T4-1 } \\
T 7-7\end{array}$ & $\begin{array}{l}77 \\
77\end{array}$ & $\begin{array}{l}150 \\
150\end{array}$ & $\begin{array}{l}53.5 \\
55.4\end{array} 54.4^{*}$ & $\begin{array}{l}62.4 \\
63.9\end{array} 63.2^{*}$ & $\begin{array}{l}24.3 \\
16.8\end{array} 20.6^{*}$ & ${ }_{8.3}^{8.6} 8.5^{*}$ & $\begin{array}{l}48.5 \\
48.5\end{array} 48.5^{*}$ & $\begin{array}{r}98.0 \\
106.7 \\
102.35^{5}\end{array}$ \\
\hline $\begin{array}{l}\text { T6-1 } \\
\text { T5-7 }\end{array}$ & $\begin{array}{l}300 \\
300\end{array}$ & $\begin{array}{l}150 \\
150\end{array}$ & $\begin{array}{l}38.1 \\
35.6\end{array} 36.9^{*}$ & $\frac{44.1}{42.6} 43.4^{*}$ & $\begin{array}{l}34.5 \\
39.6\end{array} 37.1^{*}$ & $\begin{array}{l}21.6 \\
20.7\end{array} 21.2^{*}$ & $\begin{array}{l}61.3 \\
60.3\end{array} 60.8^{*}$ & $\begin{array}{l}88.5 \\
86.3^{87 .} 40^{*}\end{array}$ \\
\hline $\begin{array}{l}\text { T3-6 } \\
\text { T3-7 }\end{array}$ & $\begin{array}{l}600 \\
600\end{array}$ & $\begin{array}{l}150 \\
150\end{array}$ & $\begin{array}{l}20.4 \\
19.7 \\
20.1^{*}\end{array}$ & $\begin{array}{l}27.9 \\
27.0 \\
27.5^{*}\end{array}$ & $\begin{array}{l}32.4 \\
31.6\end{array} 32.0^{*}$ & $\begin{array}{l}14.9 \\
14.3\end{array} 14.6^{*}$ & $\begin{array}{l}79.6 \\
79.7\end{array} 79.7^{*}$ & 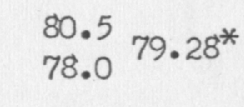 \\
\hline $\begin{array}{l}\text { T3-8 } \\
\text { T5-8 }\end{array}$ & $\begin{array}{l}800 \\
800\end{array}$ & $\begin{array}{l}150 \\
150\end{array}$ & $\begin{array}{l}18.2 \\
17.6 \\
17.9^{*}\end{array}$ & $\begin{array}{l}23.5 \\
23.4\end{array} 23.5^{*}$ & $\begin{array}{l}19.0 \\
17.0\end{array} 18.0^{*}$ & $\begin{array}{l}7.1 \\
5.8\end{array} 6.4^{*}$ & $\begin{array}{l}82.5 \\
76.7\end{array} 79.6^{*}$ & $\begin{array}{l}68.5 \\
51.059 .80^{*}\end{array}$ \\
\hline $\begin{array}{l}\text { TI-8 } \\
\text { T4-2 }\end{array}$ & $\begin{array}{l}1000 \\
1000\end{array}$ & $\begin{array}{l}150 \\
150\end{array}$ & $\begin{array}{l}13.2 \\
12.3\end{array} 12.8^{*}$ & $\begin{array}{l}15.8 \\
14.8 \\
14.3^{*}\end{array}$ & $\begin{array}{l}38.0 \\
35.8\end{array} 36.9^{*}$ & $\begin{array}{l}4.5 \\
3.9 \\
4.2^{*}\end{array}$ & ${ }_{88.0}^{88.6} 88.3^{*}$ & $\begin{array}{l}52.1 \\
47.9\end{array} 50.0^{*}$ \\
\hline $\begin{array}{l}\text { T5-9 } \\
\text { T5-10 }\end{array}$ & $\begin{array}{l}77 \\
77\end{array}$ & $\begin{array}{l}500 \\
500\end{array}$ & $\begin{array}{l}54.7 \\
54.9 \\
54.8^{*}\end{array}$ & $\begin{array}{l}65.7 \\
66.3\end{array} 66.0^{*}$ & $\begin{array}{l}19.2 \\
20.0\end{array}$ & $\begin{array}{l}7.2 \\
7.5\end{array} 7.4^{*}$ & $\begin{array}{l}41.7 \\
41.8\end{array} 41.8^{*}$ & $\begin{array}{l}94.0 \\
94.9\end{array} 94.5^{*}$ \\
\hline $\begin{array}{l}\text { T3-10 } \\
\text { T2-4 }\end{array}$ & $\begin{array}{l}300 \\
300\end{array}$ & $\begin{array}{l}500 \\
500\end{array}$ & $\begin{array}{l}39.0 \\
39.0\end{array} 39.0^{*}$ & $\begin{array}{l}46.5 \\
47.3\end{array} 46.9^{*}$ & $\begin{array}{l}30.5 \\
27.8 \\
29.2^{*}\end{array}$ & $\begin{array}{l}5.3 \\
5.3^{3}\end{array} 3^{*}$ & $\begin{array}{l}57.0 \\
59.0\end{array} 58.0^{*}$ & $\begin{array}{l}83.7 \\
92.788 .2^{*}\end{array}$ \\
\hline $\begin{array}{l}\text { T3-9 } \\
\text { TI-9 }\end{array}$ & $\begin{array}{l}600 \\
600\end{array}$ & $\begin{array}{l}500 \\
500\end{array}$ & $\begin{array}{l}23.0 \\
24.4\end{array} 23.7^{*}$ & $\begin{array}{l}29.8 \\
30.8\end{array} 30.1^{*}$ & $\begin{array}{l}22.6 \\
21.1 \\
21.9^{*}\end{array}$ & $\begin{array}{r}9.6 \\
10.2\end{array} 9.9^{*}$ & $\begin{array}{l}79.5 \\
78.1\end{array} 78.8^{*}$ & ${ }_{86.4}^{85.2} 85.8^{*}$ \\
\hline $\begin{array}{l}\text { T2-5 } \\
\text { T1-10 }\end{array}$ & $\begin{array}{l}800 \\
800\end{array}$ & $\begin{array}{l}500 \\
500\end{array}$ & $\begin{array}{l}20.5 \\
21.6^{21.1^{*}}\end{array}$ & $\begin{array}{l}25.0 \\
27.1\end{array} 26.1^{*}$ & $\begin{array}{l}15.1 \\
17.6 \\
16.4^{*}\end{array}$ & $\begin{array}{l}3.9 \\
5.3\end{array} 4.6^{*}$ & $\begin{array}{l}82.6 \\
82.5\end{array} 82.6^{*}$ & $\begin{array}{l}65.7 \\
58.5\end{array} 62.1^{*}$ \\
\hline $\begin{array}{l}\text { T7-8 } \\
\text { T3-11 }\end{array}$ & $\begin{array}{l}1000 \\
1000\end{array}$ & $\begin{array}{l}500 \\
500\end{array}$ & $\begin{array}{l}13.1 \\
12.7 \\
12.9^{*}\end{array}$ & $\begin{array}{l}14.6 \\
15.5 \\
15.1^{*}\end{array}$ & $\begin{array}{l}38.3 \\
60.5\end{array} 49.5^{*}$ & $\begin{array}{l}5.4 \\
3.5\end{array} 4.0^{*}$ & $\begin{array}{l}90.0 \\
89.0 \\
89.5^{*}\end{array}$ & $\begin{array}{l}45.0 \\
40.9 \\
43.0^{*}\end{array}$ \\
\hline \multicolumn{9}{|c|}{ Notched, Normal Grain Size } \\
\hline $\begin{array}{l}T 6-2 \\
T 4-3\end{array}$ & $\begin{array}{l}77 \\
77\end{array}$ & $\begin{array}{l}12 \\
12\end{array}$ & $\overline{-}$ & $\begin{array}{l}102.0 \\
100.0 \\
101.0^{*}\end{array}$ & $\overline{-}$ & - & $\begin{array}{l}19.4 \\
12.1 \\
15.3^{*}\end{array}$ & $\begin{array}{l}58.2 \\
46.0\end{array} 52.1^{*}$ \\
\hline $\begin{array}{l}T 5-2 \\
T 7-3\end{array}$ & $\begin{array}{l}300 \\
300\end{array}$ & $\begin{array}{r}12 \\
2\end{array}$ & - & $\begin{array}{l}71.7 \\
72.7\end{array} 72.2^{*}$ & $\overline{-}$ & - & $\begin{array}{l}19.2 \\
24.2\end{array} 21.7^{*}$ & $\begin{array}{l}43.8 \\
56.049 .9^{*}\end{array}$ \\
\hline $\begin{array}{l}T 5-3 \\
T 6-4\end{array}$ & $\begin{array}{l}600 \\
600\end{array}$ & $\begin{array}{l}12 \\
12\end{array}$ & - & $\begin{array}{l}45.6 \\
45.7\end{array} 45.7^{*}$ & - & - & $\begin{array}{l}39.6 \\
48.0\end{array} 43.8^{*}$ & $\begin{array}{l}27.6 \\
43.1\end{array} 35.4^{*}$ \\
\hline $\begin{array}{l}\text { T6-7 } \\
\text { T3-2 }\end{array}$ & $\begin{array}{l}1000 \\
1000\end{array}$ & $\begin{array}{l}12 \\
12\end{array}$ & - & $\begin{array}{l}38.5 \\
32.6\end{array} 35.6^{*}$ & - & - & - & - \\
\hline $\begin{array}{l}\text { T2-13 } \\
\text { T1-17 }\end{array}$ & $\begin{array}{l}77 \\
77\end{array}$ & $\begin{array}{l}150 \\
150\end{array}$ & - & $\begin{array}{l}99.4 \\
98.1 \\
98.7^{*}\end{array}$ & - & - & $\begin{array}{l}5.8 \\
7.7\end{array} 6.8^{*}$ & $\begin{array}{l}104.0 \\
104.0\end{array} 104.0^{*}$ \\
\hline $\begin{array}{l}\text { T7-18 } \\
\text { T3-13 }\end{array}$ & $\begin{array}{l}300 \\
300\end{array}$ & $\begin{array}{l}150 \\
150\end{array}$ & $\overline{-}$ & $\begin{array}{l}72.3 \\
65.2\end{array} 68.8^{*}$ & - & - & $\begin{array}{l}12.5 \\
26.0\end{array} 19.3^{*}$ & $\begin{array}{l}61.5 \\
58.9\end{array} 60.2^{*}$ \\
\hline $\begin{array}{l}T 4-13 \\
T 4-4\end{array}$ & $\begin{array}{l}600 \\
600\end{array}$ & $\begin{array}{l}150 \\
150\end{array}$ & - & $\begin{array}{l}44.2 \\
45.5\end{array} 44.9^{*}$ & - & - & ${ }_{47.1}^{-} 47.1^{*}$ & $27.3^{-} 27.3^{*}$ \\
\hline $\begin{array}{l}T 5-12 \\
T 7-9\end{array}$ & $\begin{array}{l}77 \\
77\end{array}$ & $\begin{array}{l}500 \\
500\end{array}$ & - & ${ }_{101.0}^{100.9} 101.0^{*}$ & - & - & $\begin{array}{l}7.3 \\
3.8\end{array} 5.6^{*}$ & $\begin{array}{l}108.9 \\
104.9\end{array} 106.9^{*}$ \\
\hline $\begin{array}{l}\text { T1-11 } \\
\text { T5-11 }\end{array}$ & $\begin{array}{l}300 \\
300\end{array}$ & $\begin{array}{l}500 \\
500\end{array}$ & - & $\begin{array}{l}76.9 \\
75.2\end{array} 76.1^{*}$ & - & - & ${ }_{11.5}^{13.3} 12.4^{*}$ & ${ }^{72.8} 72.8^{*}$ \\
\hline $\begin{array}{l}\text { T3-12 } \\
\text { T7-10 }\end{array}$ & $\begin{array}{l}600 \\
600\end{array}$ & $\begin{array}{l}500 \\
500\end{array}$ & - & $\begin{array}{l}50.5 \\
46.6\end{array} 48.6^{*}$ & - & - & ${ }^{31.4} 31.4^{*}$ & ${ }^{15.2} 15.2^{*}$ \\
\hline T7-17 & 800 & 500 & - & 40.4 & - & - & - & - \\
\hline
\end{tabular}




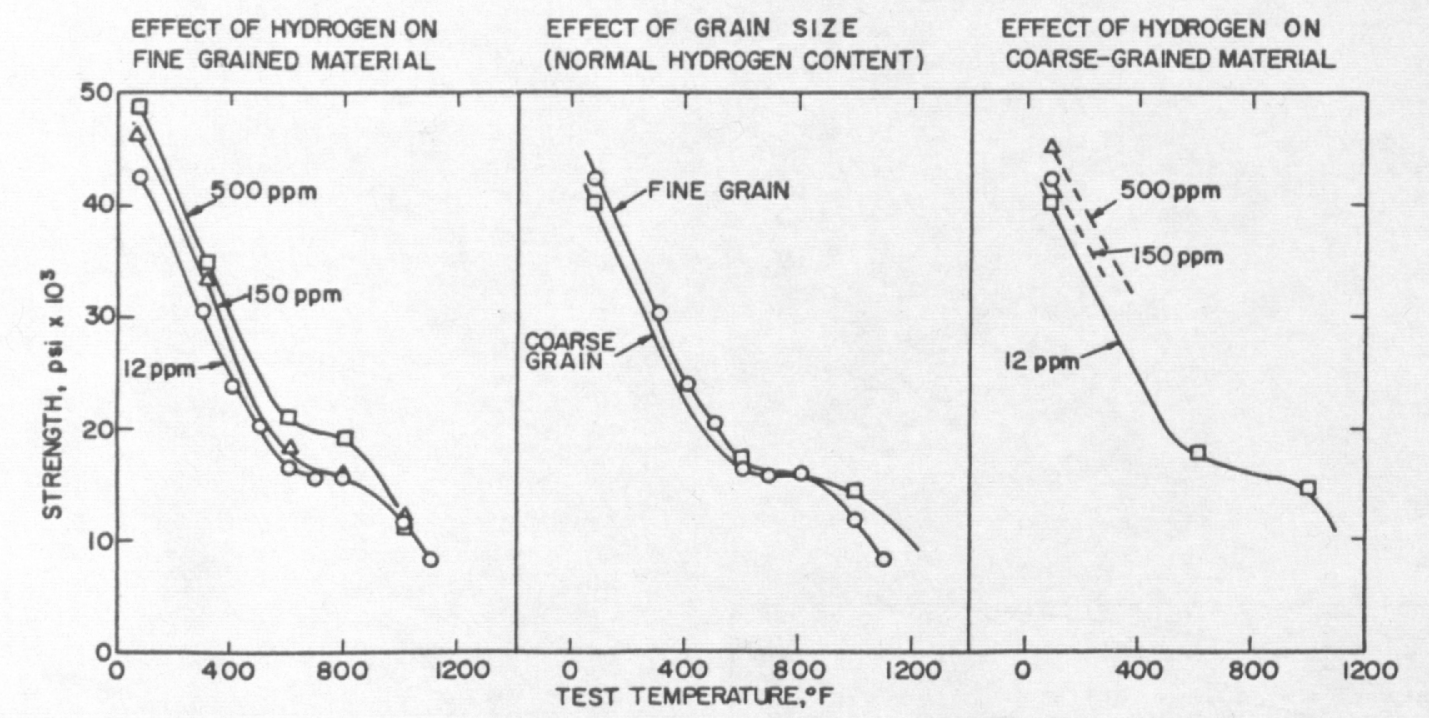

FIGURE 12 . EFFECT OF HYRORGEN CONTENT, GRAIN SIZE, AND TEMPERATURE, ON THE
O.2\% YIELD STRENGTH OF ZIRCALOY 2 TESTED LONGITUDINAL TO ROLLLING

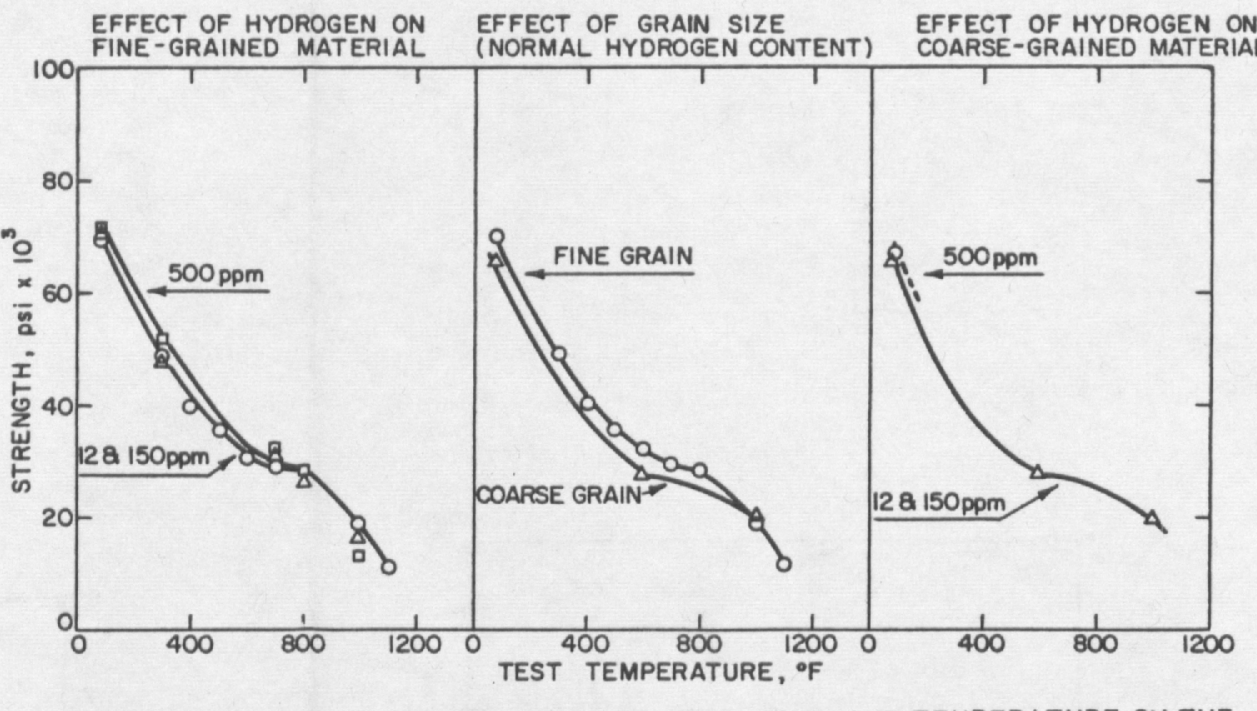

FILURE 13. EFFECT OF HYOROGENCONTENT, GRAIN SIZE, AND TEMPERATURE ON THE
ULTTMATE TENSLLE STRENGTH OF ZIRCALOY-2 TESTED LONGITUDINALLY TO ROLLING

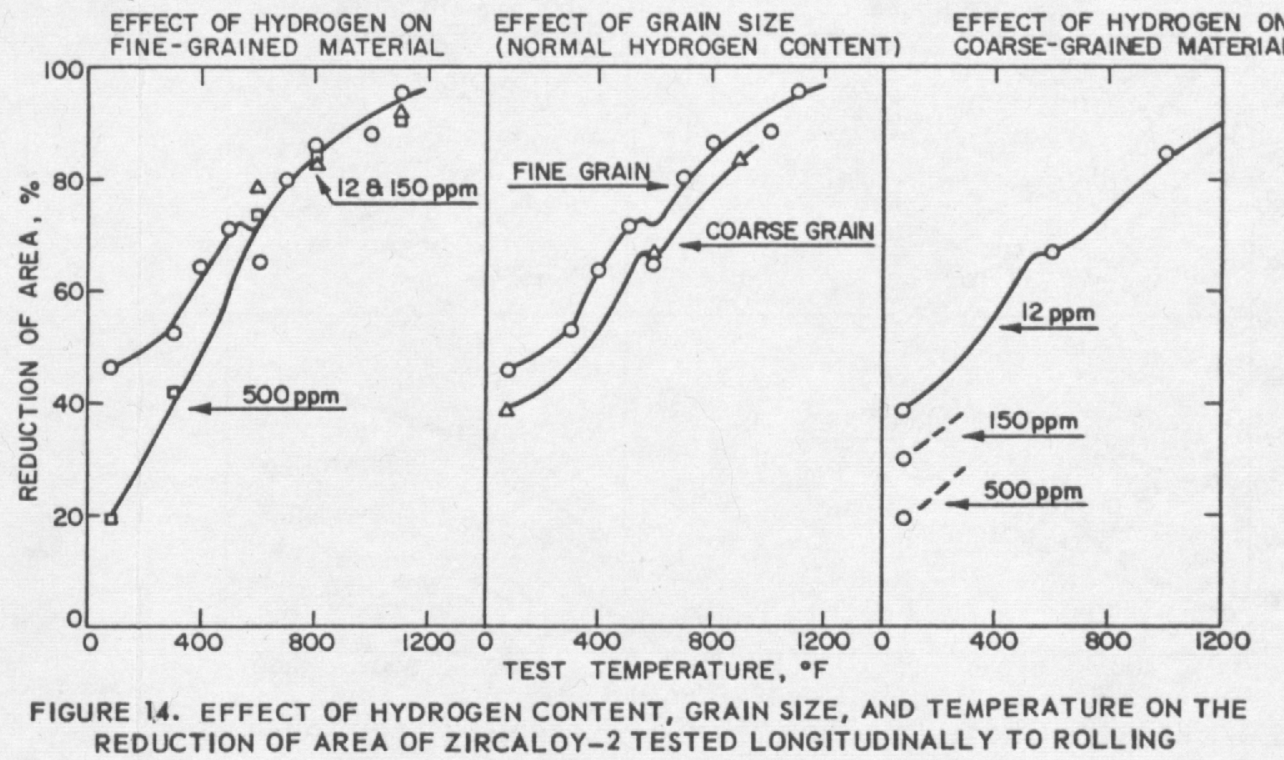

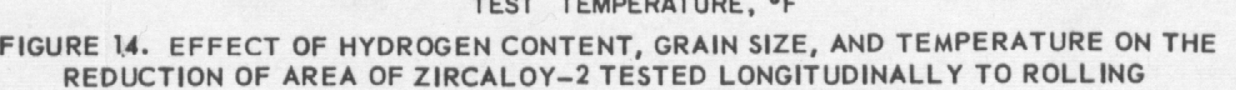

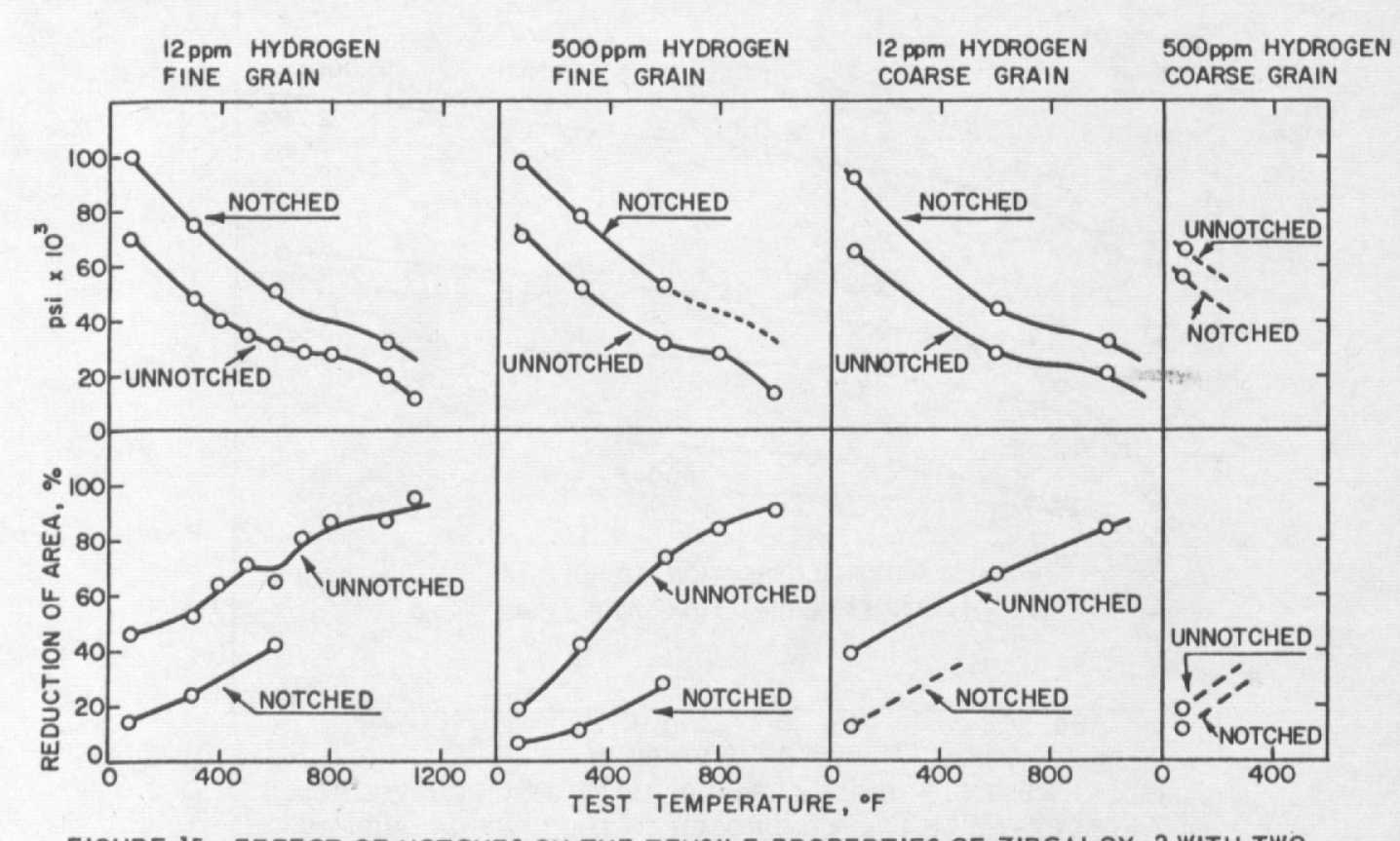

FIGURE 15. EFFECT OF NOTCHES ON THE EENSLE PROPERTIES OF IRRCALOY-2 WITH TWO
HYROGEN CONTENTS AND TWO GRAIN SIIES TESTED IN THE LONGITUDINAL DIRECTION
TO ROLLING

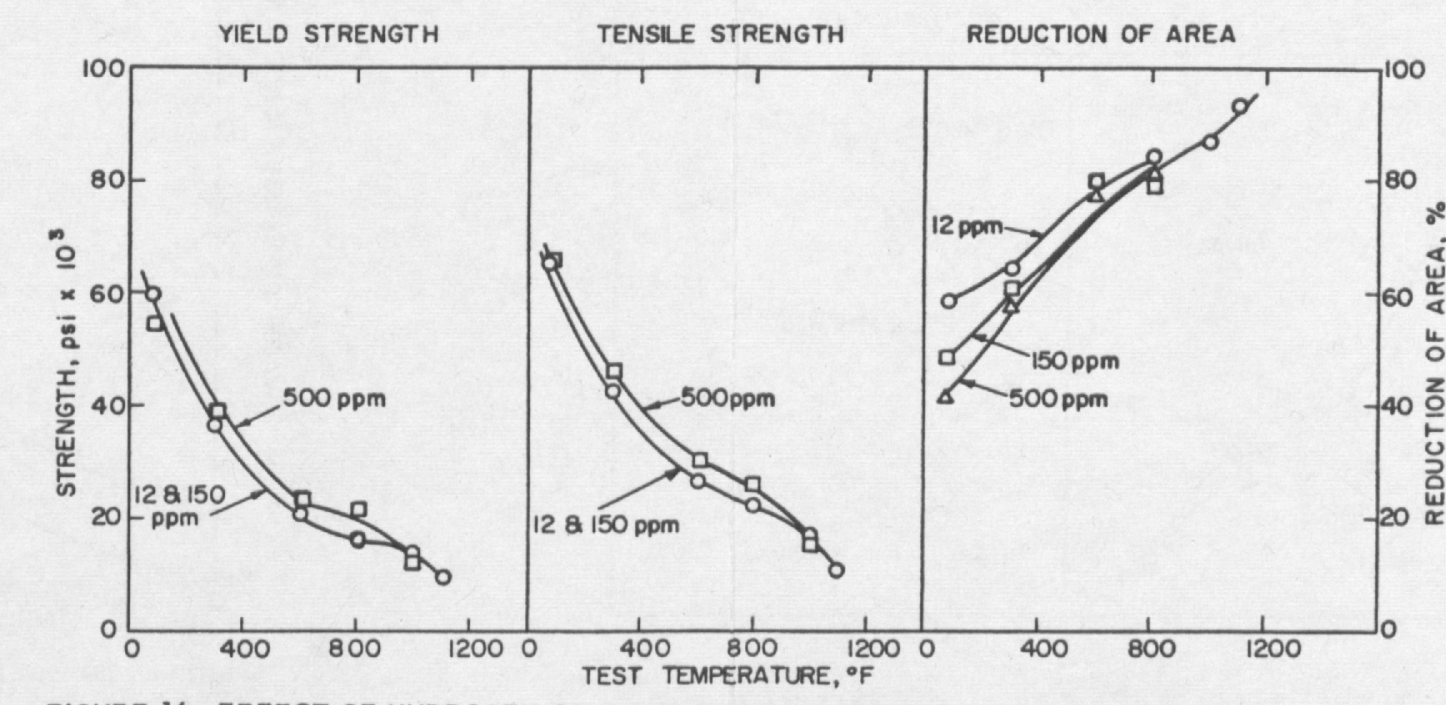

FIGURE 16. EFFECT OF HYOROGEN CONTTENT AND TEMPER FATURE ON THE TENSLLE PROPERTIES OF 


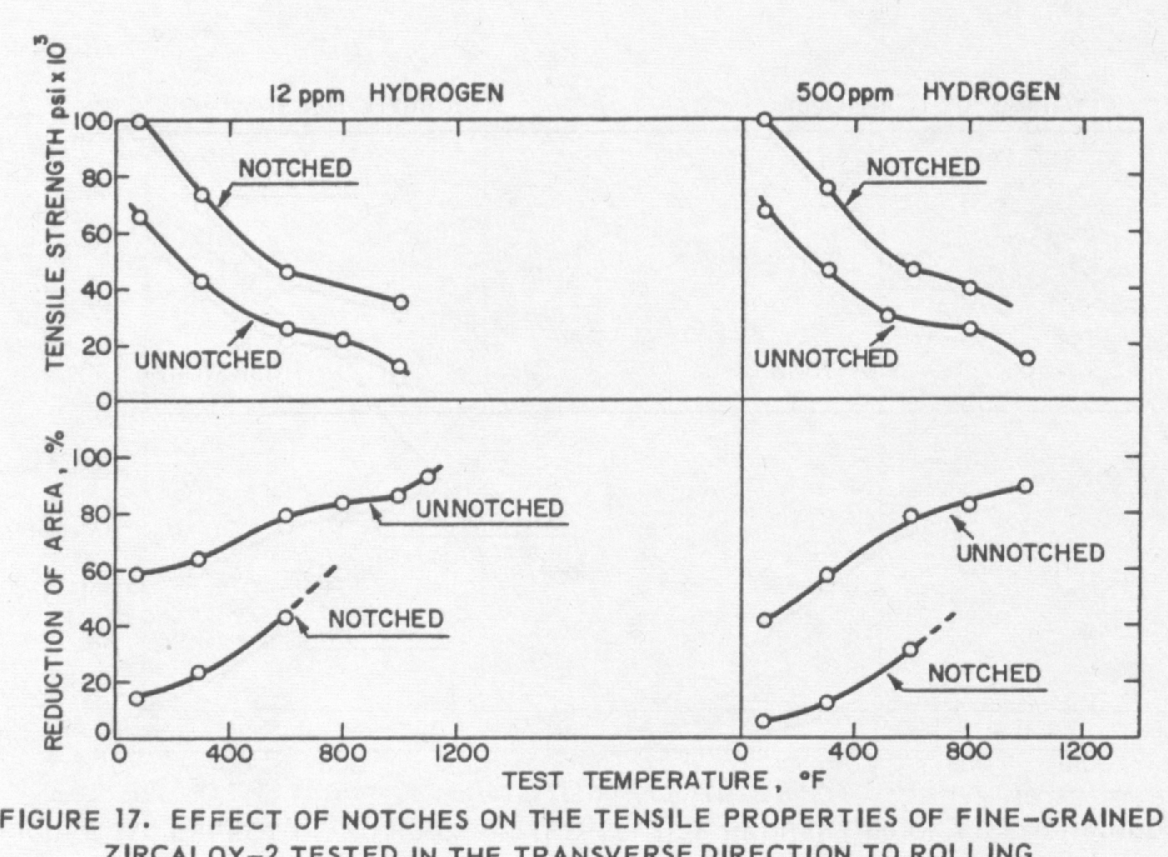

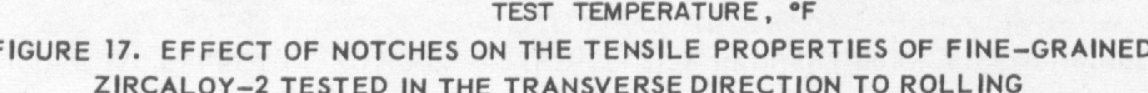

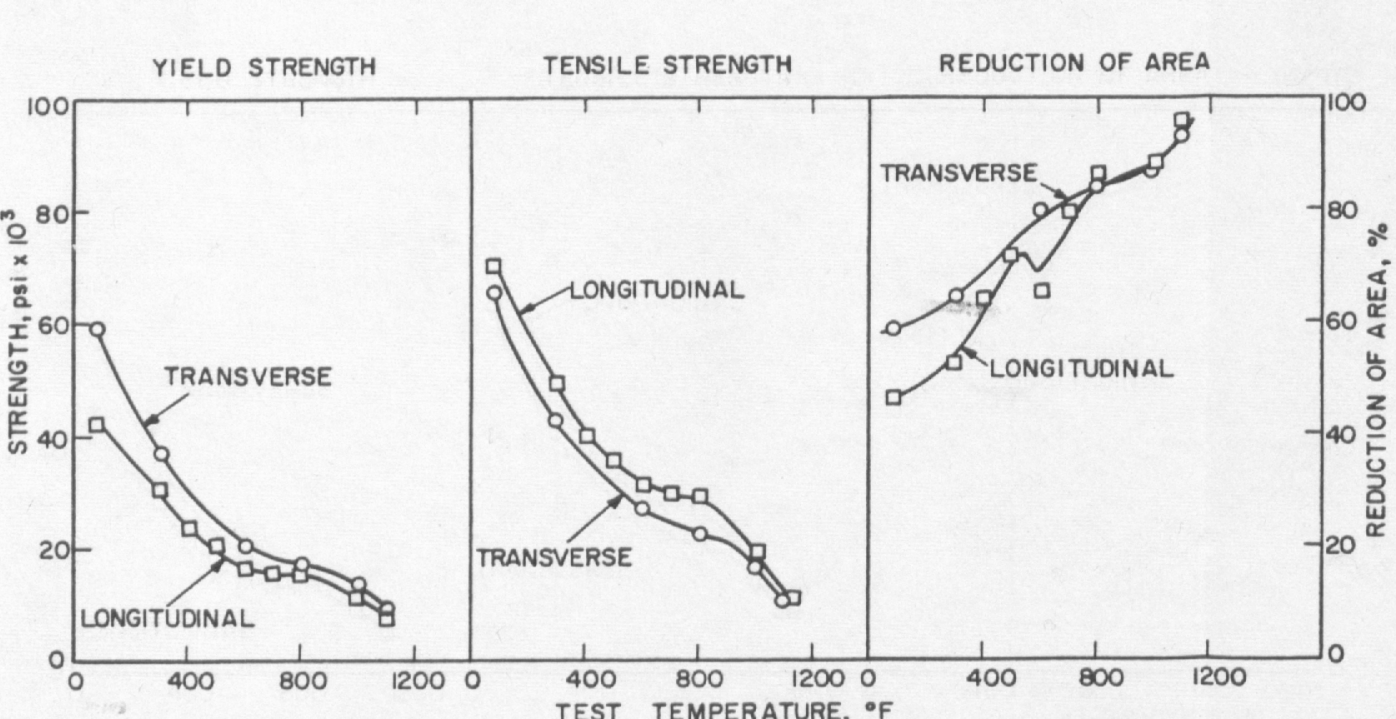

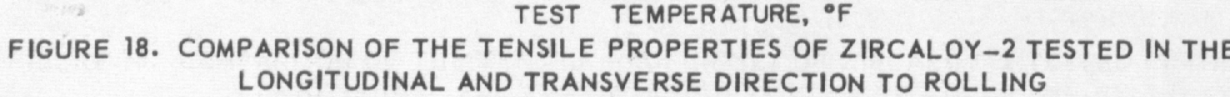

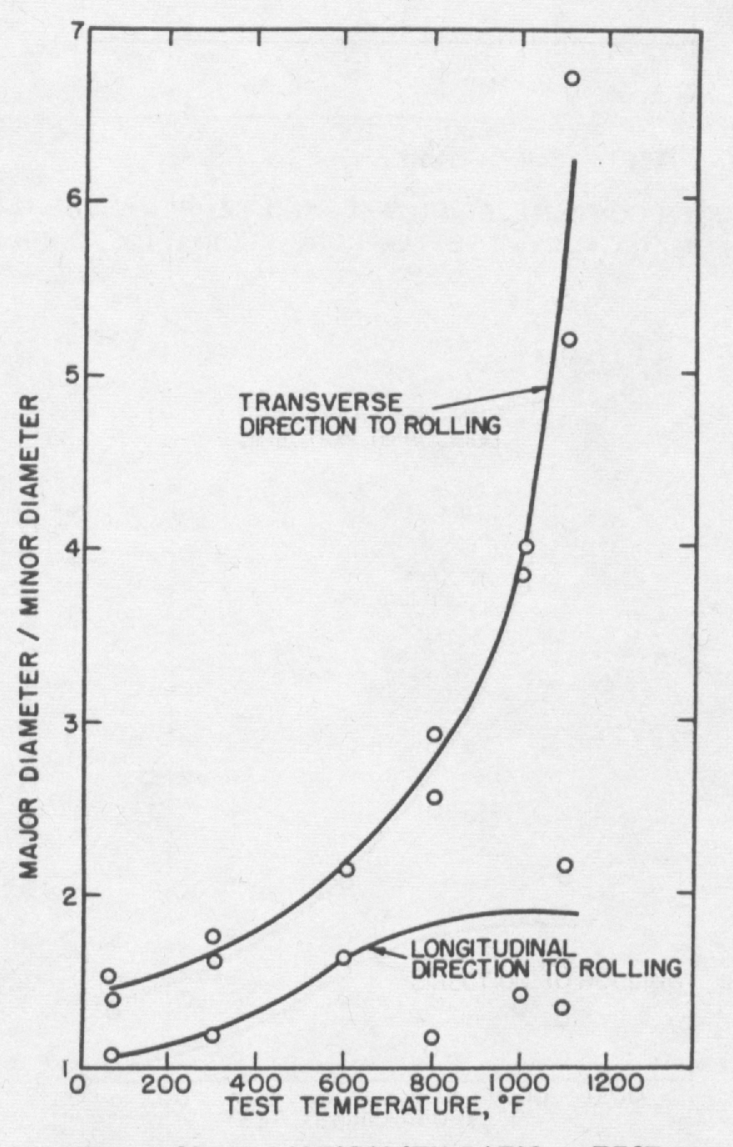

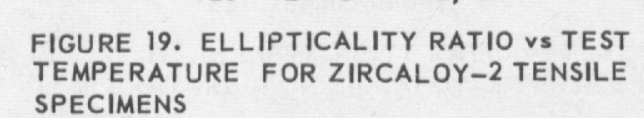

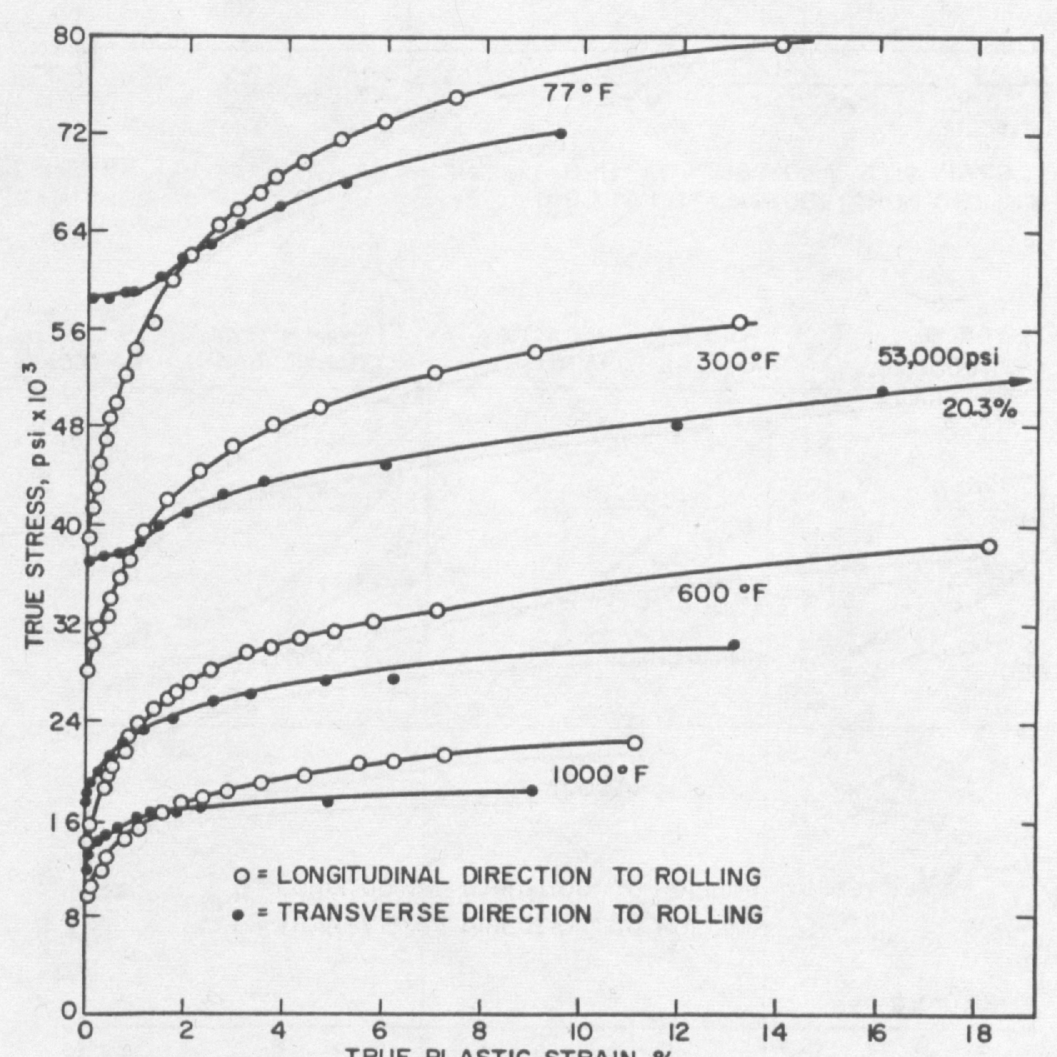

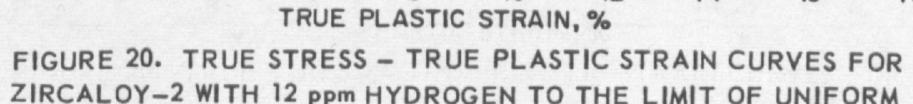




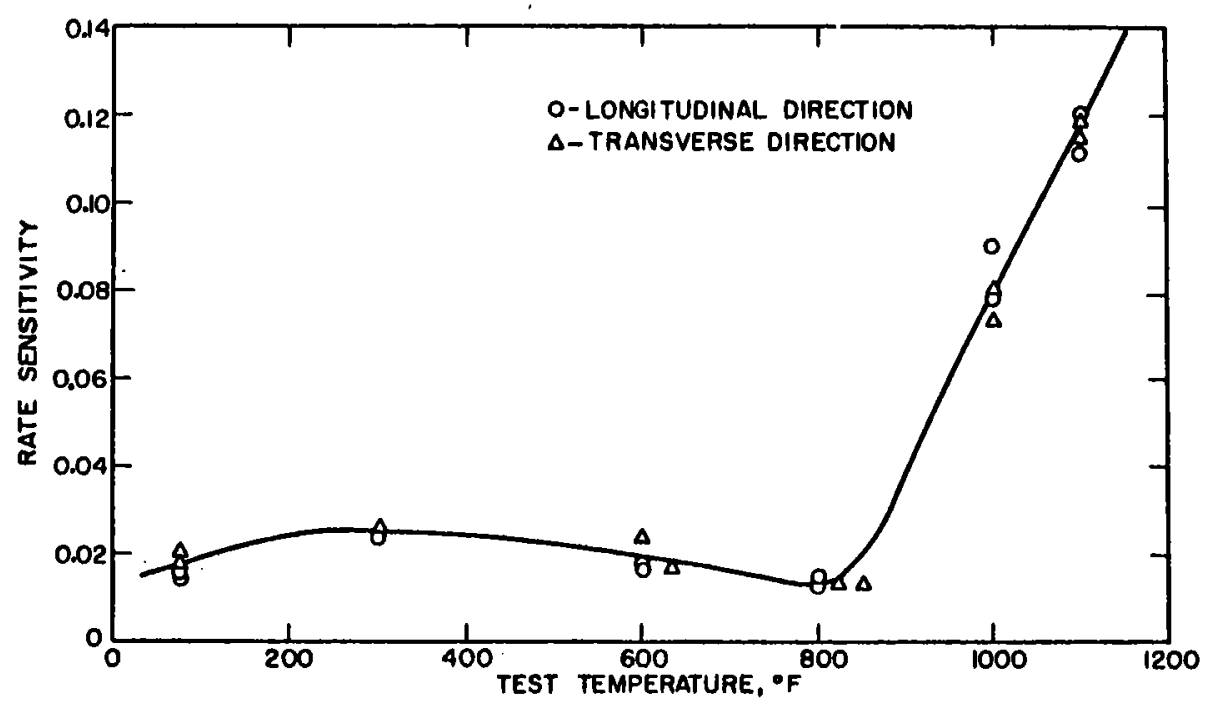

FIGURE 21. RATE SENSITIVITY OF ZIRCALOY-2 VA TEMPERATURE POR THE LONGITUDINAL AND TRANSVERSE DIRECTION TO ROLLING

Plastic stress-strain curves of fine-grained Zircaloy-2 with 12ppm hydrogen are shown in Figure 20 . These curves were constructed from the autographic record of the test, with the assumption of the constant volume condition.

One additional item of information may be extracted from the tensile data. It was the practice, when performing the tensile tests, to increase the cross-head movement by a factor of 10 after the ultimate load was reached. The primary purpose of this procedure was to save testing time, but another purpose is served by this rate increase. A value of the strain rate exponent, ${ }^{*} n$, can be calculated. This calculation was performed, and the results are shown in Figure 2l. It can be seen that the values of rate sensitivity are approximately equal for both the longitudinal and transverse directions. Although no detailed investigation of the independence of the strain rate exponent with strain level was performed, one test at $800 \% \mathrm{~F}$ indicated that $\mathrm{n}$ is substantially canstant and

*The strain rate exponent $n$ is defined as

$$
n=\left(\frac{\partial \log \sigma}{\partial \log \dot{\epsilon}}\right)_{\epsilon, T}
$$

where $\quad \sigma=$ true stress

$\dot{\epsilon}=$ true strain rate

$\epsilon=$ true strain rate

$\mathrm{T}=$ temperature. 
independent of the strain level. No information was obtained on the effect of rate changes (larger or smaller) than a factor of 10 .

Creep and Stress-Rupture Properties

Creep tests were performed in General Electric, Barker creep units modified to permit the tests to be run in an inert argon atmosphere. These creep stations are of the constant load type, with the weight applied in 5-1b increments through a 10:1 lever ratio. The extension was measured by means of extension arms clamped to the shoulder of the creep specimen, as shown in Figure 3, and extending to a 0.0001-in. dial gage through an averaging rod and tube arrangement. An hour meter connected to the machine indicated the duration of the test.

Stress-rupture tests were performed in special units designed previously for testing in liquid metal. The units consist of two stations per furnace and are top-loaded through a 5:1 lever ratio by means of lead weights. The equipment can be operated under an inert argon atmosphere. Extension was measured by means of 0.001-in. dial gages attached to the lever arms. The motion obtained consists of both the specimen deflection and the associated elastic deflection of the load shafts and takeup in the loading train. By constructing a loading curve for each test, and knowing the elastic modulus of Zircaloy-2, it was possible to remove from the deflection values all extraneous movement and obtain only the plastic deflection of the specimen. The specimen used for stress-rupture tests (show in Figure 2) is identical to the tensile specimen.

As in the conduct of the tensile tests, all creep and stress-rupture tests were performed in an inert argon atmosphere. Again, no attempt was made to purify the argon, so some oxidation occurred at higher temperatures and longer times. Both the creep and stress-rupture units had a small constant flow of argon maintained throughout the duration of the test.

A total of 70 stress-rupture specimens and 28 creep specimens were tested as a function of temperature, grain size, hydrogen content, directionality to rolling, and notch condition (either smooth or notched). These variables were not studied in as much detail as they were in the tensile tests, mainly because of the length of time required. A summary of the test variables and specimen assignments is shown in Table 9.

The creep and stress-rupture results are summarized in Tables 10 to 13, and plotted in Figures 22 to 33. From these data, the following observations are noted:

1. In general, the creep strength in the transverse direction to rolling is lower than it is in the longitudinal direction. In view of the higher yield strength in the transverse 
TABLE 9. STMMARY OF CREEP AND RUPTURE TESTS PERPCRMEED ON ZIRCALOY-2

\begin{tabular}{|c|c|c|c|c|c|c|c|c|}
\hline \multirow{5}{*}{$\begin{array}{l}\text { Teat Temperature, } \\
\text { OF }\end{array}$} & \multirow{5}{*}{$\begin{array}{c}\text { Notch } \\
\text { Condition }\end{array}$} & \multirow[b]{5}{*}{ Grain Stze } & \multicolumn{6}{|c|}{ Direction } \\
\hline & & & \multicolumn{6}{|c|}{ Iongltudinal } \\
\hline & & & \multicolumn{4}{|c|}{ Hydrogen Content, ppm } & \multirow{2}{*}{\multicolumn{2}{|c|}{$\frac{\text { Hydrogen Content, } \mathrm{ppm}}{12}$}} \\
\hline & & & \multicolumn{2}{|c|}{12} & \multicolumn{2}{|c|}{500} & & \\
\hline & & & $\mathbf{C}$ & $\underline{S-R}$ & $\mathrm{C}$ & $\underline{\mathrm{S}-\mathrm{R}}$ & \multicolumn{2}{|c|}{$\frac{12}{C \quad S-R}$} \\
\hline \multirow[t]{4}{*}{300} & Unnotahed & Normal & 5 & 5 & - & 3 & 3 & 6 \\
\hline & & Large & - & - & - & - & - & - \\
\hline & Notched & Noxmal & - & 4 & - & - & - & - \\
\hline & & Large & - & - & - & - & - & - \\
\hline \multirow[t]{4}{*}{600} & Unnotched & Normal & 6 & 4 & - & 2 & 4 & 5 \\
\hline & & Large & - & 6 & - & - & - & - \\
\hline & Notched & Normal. & - & 6 & - & - & - & - \\
\hline & & Large & - & - & - & - & - & - \\
\hline \multirow[t]{4}{*}{800} & Unnotched & Normal & 3 & 6 & - & 4 & 2 & 4 \\
\hline & & Large & - & - & - & - & - & - \\
\hline & Notched & Normal & - & - & - & - & - & - \\
\hline & & Large & - & - & - & - & - & - \\
\hline \multirow[t]{5}{*}{1000} & Unnotched & Normal & 4 & 5 & - & - & 1 & 5 \\
\hline & & Large & - & - & - & - & - & - \\
\hline & Notched & Normal & - & 5 & - & - & - & - \\
\hline & & Large & - & - & - & - & - & - \\
\hline & & $\begin{aligned} C & = \\
\mathrm{SR} & =\end{aligned}$ & reep & $\begin{array}{l}\text { Test } \\
\text {-Rupt }\end{array}$ & & & & \\
\hline
\end{tabular}

direction, this is a somewhat surprising result. The reasons for this behavior are discussed below.

2. In both the longitudinal and transverse directions, the creep behavior at $600^{\circ} \mathrm{F}$ is characterized by extremely low creep rates. This behavior is typical of a strainaging material. The ramifications of this behavior and the relationship between these results and the tensile test results also are discussed below.

3. Zircaloy-2, in general, does not exhibit a so-called "minimum creep rate." Although some apparent minimum creep rates may be extracted from the original straintime curves, such results are likely to be misleading. Consequently, if creep rates are required in order to develop analytical relations between stress, strain, and time, the curves shown in Figures 22 to 30 should be cross-plotted at constant stress to obtain "faired" strain-time curves, and creep rates may be obtained from these derived curves. 
4. The effect of $500 \mathrm{ppm}$ hydrogen on the rupture strength of Zircaloy-2, as shown in Figure 32, is negligible. This is true also for the rupture ductility.

5. The effect of grain size on rupture properties was studied at $600^{\circ} \mathrm{F}$ only (see Table 12). Because of the extremely flat rupture curve, no long-term failures were obtained. Consequently, the conclusion as to the effect of grain size is that it is identical to that obtained in the tensile tests; that is, a small amount of strength reduction is obtained.

6. The smail number of notch rupture tests performed (see Figure 33) revealed no long-term detrimental effect of notches on rupture strengths. The notch strength ratio (ratio of notch strength to unnotched strength) is of the same order as in the tensile tests, which indicates that Zircaloy-2 is notch insensitive to long-term as well as short-term loading conditions.

Low-Cycle Fatigue

Low-cycle fatigue tests were performed in machines similar to those described by E. E. Baldwin, G. J. Sokol, and I. F. Coffin.13 As in the tensile and creep tests, all elevated temperature tests were performed in an inert atmosphere. The specimens used for these tests are shown in Figure 4, and the notch detail used in the notched fatigue tests is shown in Figure 8.

Low-cycle fatigue tests differ from conventional stress fatigue tests in that the strain range is controlled during the tests rather than the stress. This difference between the two types of test is quite important when a large departure from linearity occurs between stress and strain, as is the case when the number of cycles required for failure is low. As strain range is the important variable to measure and control during strain-fatigue testing, accurate means must be employed to determine this quantity. In these tests, the strain range was set by means of the tension and compression stops in the machine and optically measured by means of a cathetometer sighting on the gage length of the specimen. A quartz window was built into the furnace assembly surrounding the specimen to allow this measurement to be made. Strain values were obtained throughout the test, and if they departed by a large amount from the initial value (taken after about 75 cycles), the test was discarded. The variation of stress during the test was also measured by means of a tension bar, instrumented with strain gages, in series with the specimen.

The fatigue tests were performed at a frequency of about 10 cycles per minute. All tests were performed with a zero mean strain; that is, 


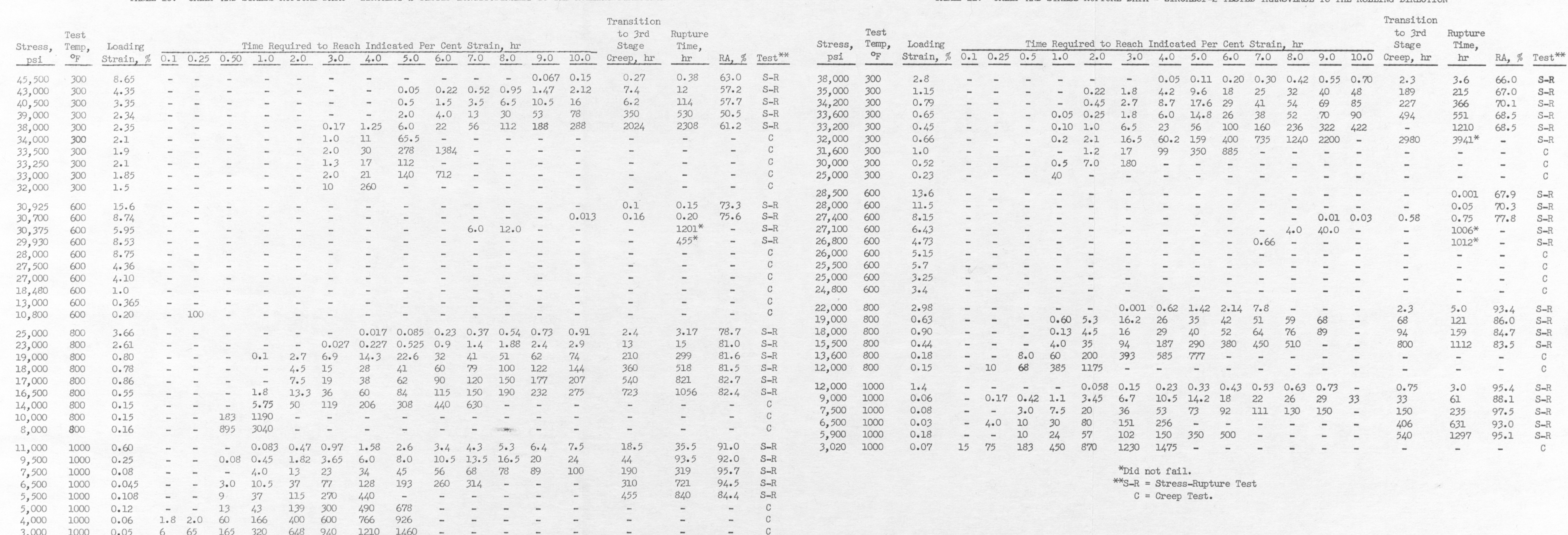

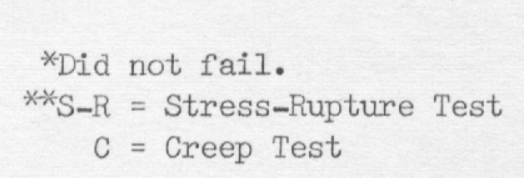


TABIE 12. FFFECT OF HYDROGEN, NOYCHES, AND GRATN SIZE ON STRESS-RUPTURE AND CREEP PROPERTIRS OF ZIRCALOY-2

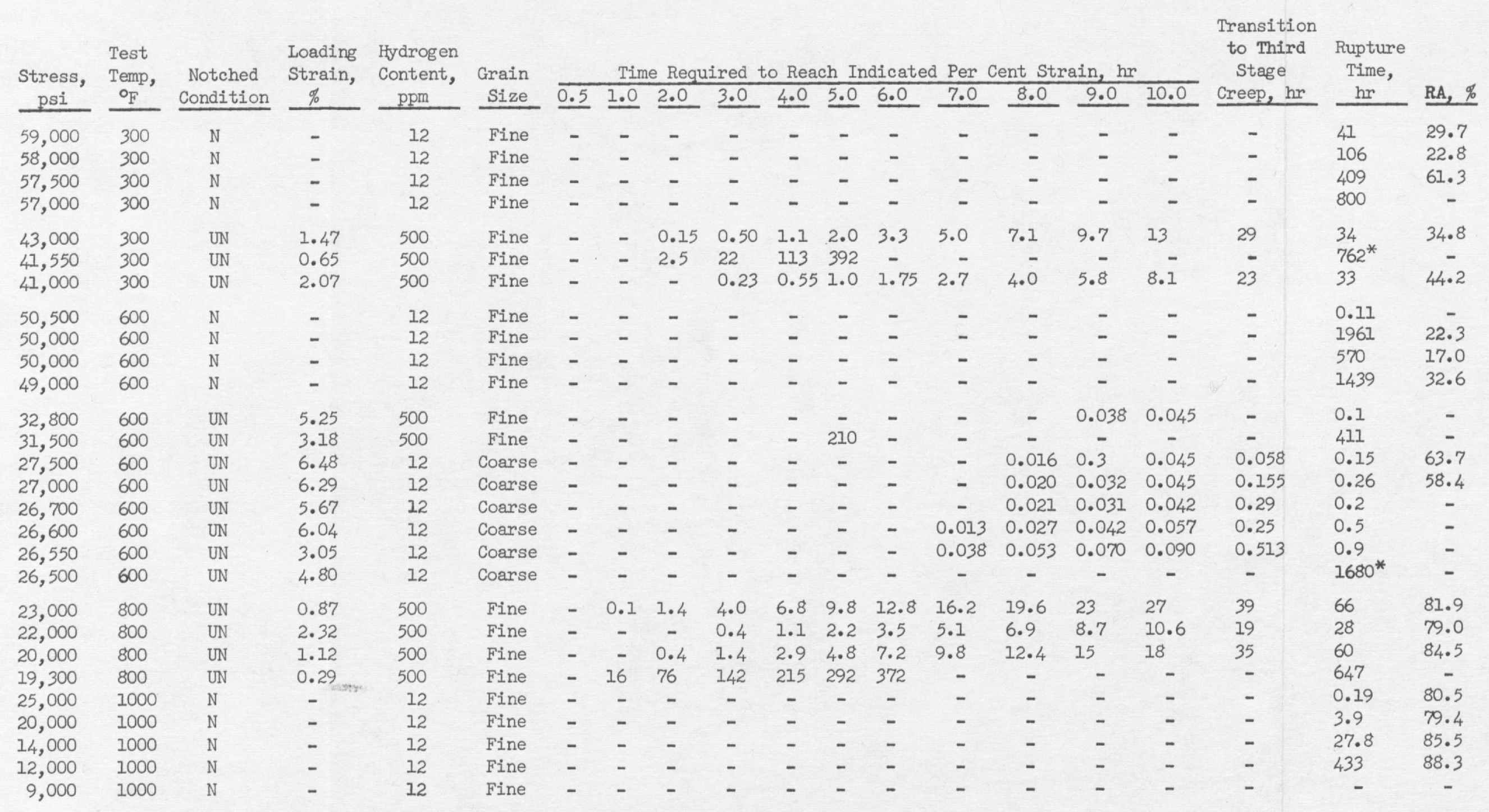

TABLE 13. STRESS-RUPTURE PROPERTTES OF NOTCHED ZIRCALOY-2

TESTRD LONGITUDTNALUY TO THE ROLITNG DIRECTION -

\begin{tabular}{|c|c|c|c|}
\hline $\begin{array}{c}\text { Stress, } \\
\text { psi } \\
\end{array}$ & $\begin{array}{c}\text { Test } \\
\text { Temperature, } \\
\mathrm{or}_{\mathrm{F}} \\
\end{array}$ & $\begin{array}{l}\text { Rupture } \\
\text { Time, } h r\end{array}$ & $\begin{array}{l}\text { Reduction of Area } \\
\text { at Base of } \\
\text { Notch, \% }\end{array}$ \\
\hline $\begin{array}{l}59,000 \\
58,000 \\
57,500 \\
57,000\end{array}$ & $\begin{array}{l}300 \\
300 \\
300 \\
300\end{array}$ & $\begin{array}{l}41.3 \\
106 \\
409 \\
800\end{array}$ & $\begin{array}{c}18.8 \\
22.9 \\
29.7 \\
-\end{array}$ \\
\hline $\begin{array}{l}51,500 \\
5,500 \\
50,000 \\
50,000 \\
50,000 \\
49,500 \\
49,000\end{array}$ & $\begin{array}{l}600 \\
600 \\
600 \\
600 \\
600 \\
600 \\
600\end{array}$ & $\begin{array}{c}0.1 \\
0.11 \\
0.11 \\
570 \\
50.01 \\
0.01 \\
1439\end{array}$ & $\begin{array}{c}\overline{-} \\
22.3 \\
17.0 \\
\overline{-} \\
32.6\end{array}$ \\
\hline $\begin{array}{l}25,000 \\
2,0,000 \\
14,0,000 \\
12,000 \\
9,000\end{array}$ & $\begin{array}{l}1000 \\
1000 \\
1000 \\
1000 \\
1000\end{array}$ & $\begin{array}{c}0.19 \\
3.9 \\
27.8 \\
434 \\
1580 *\end{array}$ & $\begin{array}{l}84 \\
79 \\
85 \\
88 \\
-\end{array}$ \\
\hline
\end{tabular}




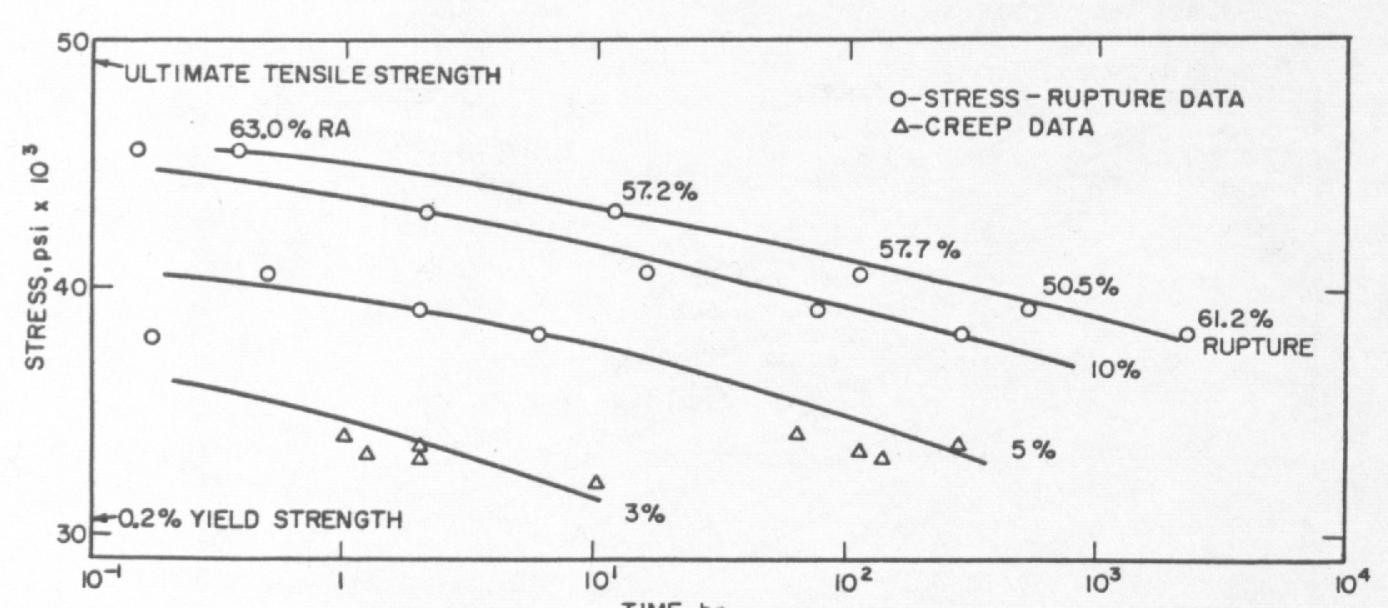

FIGURE 22. STRESS REQUIRED FOR VARIOUS MAE, UN.
TESTS OF TOTALD DEFORMATIION FOR FIIRCALOY-2

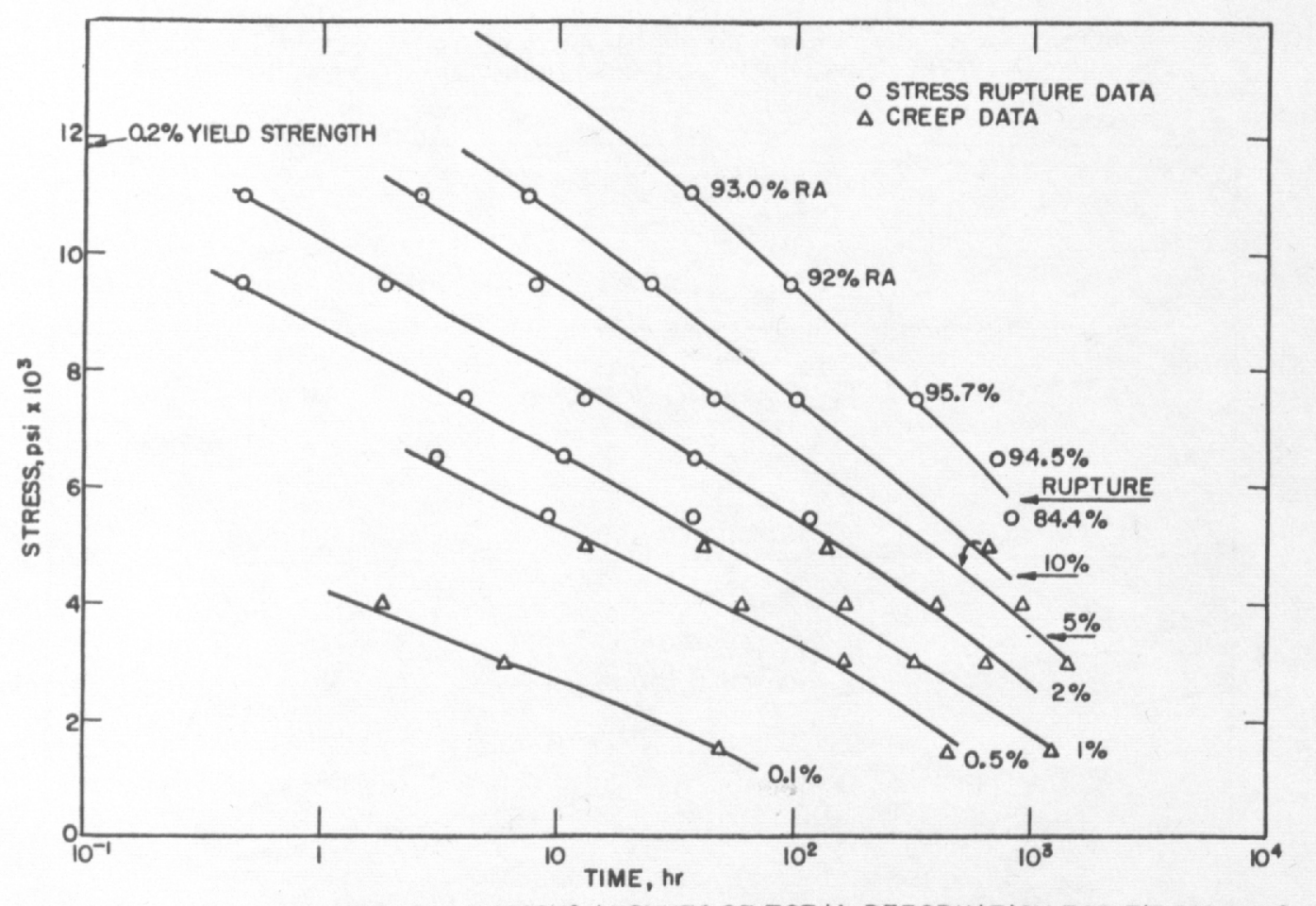

FIGURE 25. STRESS REQUIRED FOR VARIOUS AMOUNTS OF TOTAL DEF FRMATION FOR ZIIRCALOY-2
TESTED LONGITUDINALLY TO THE ROLLLING DIRECTION AT 1000

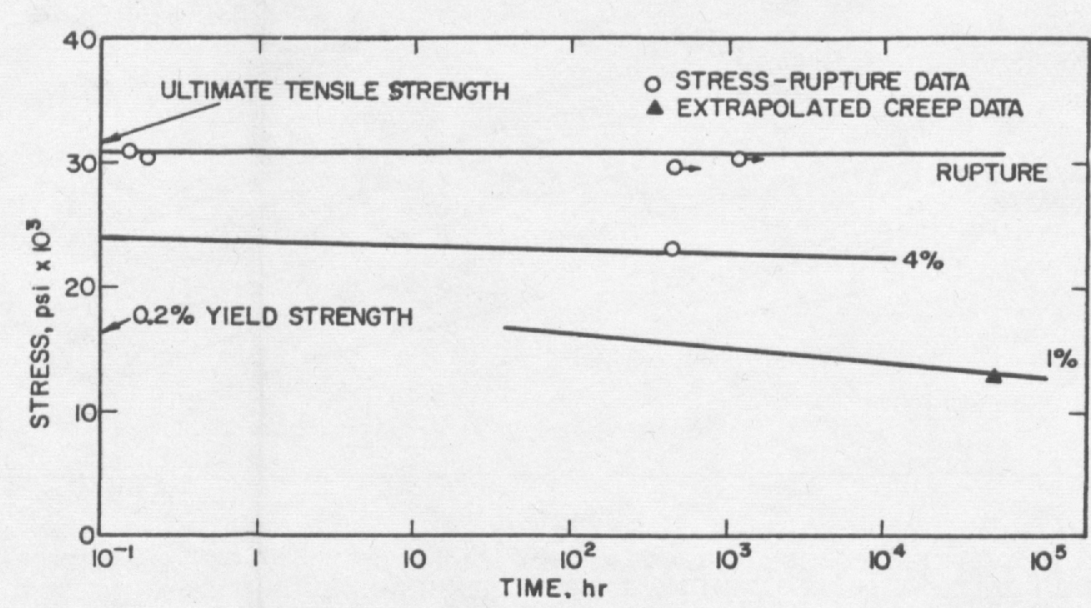

FIGURE 23. STRESS REQUIRED FOR VARIOUS AMOUNTS OF TOTAL DEFORMA
TION FOR ZIR CLLOY-2 TESTED LONGITUDINALLY TO THE ROLLING DIREC

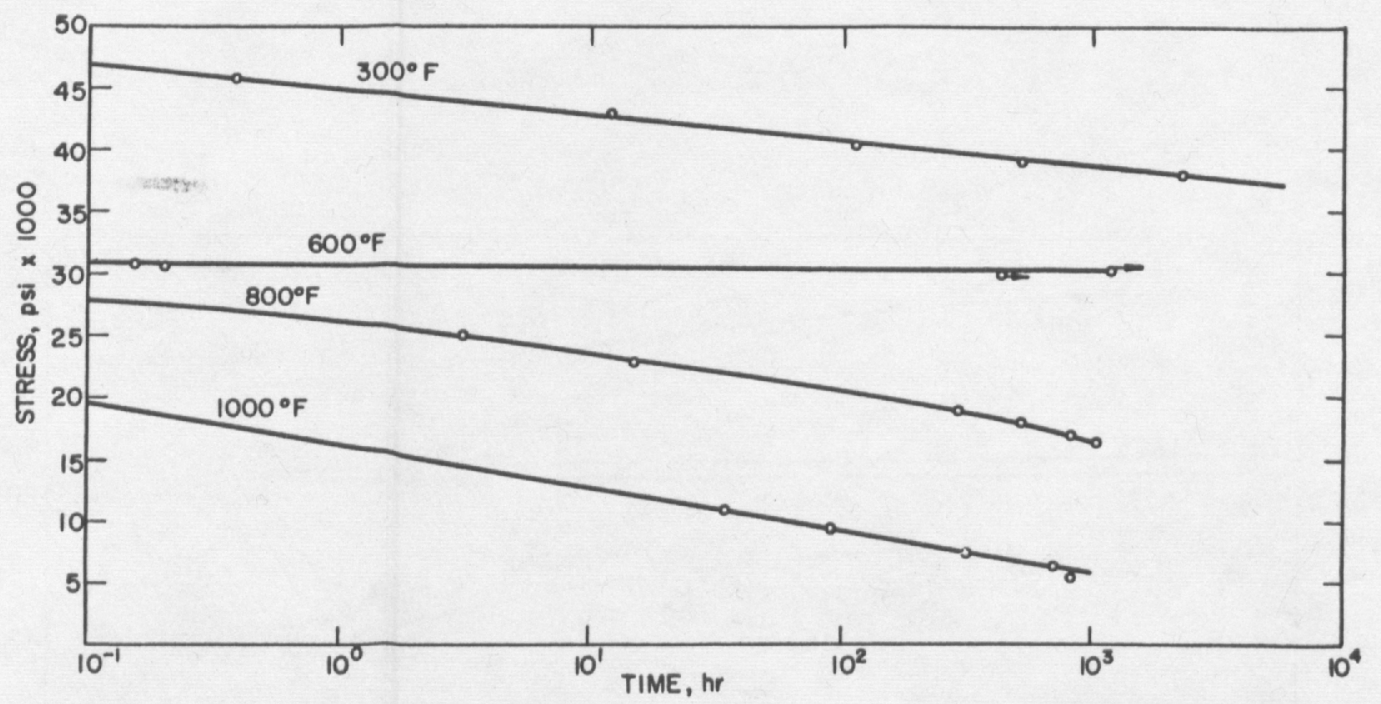

FIGURE 26. RUPTURE STRENGTH OF ZIRCALOY-2 TESTED LONGITUDINALLY TO THE ROLLING
DIRECTION

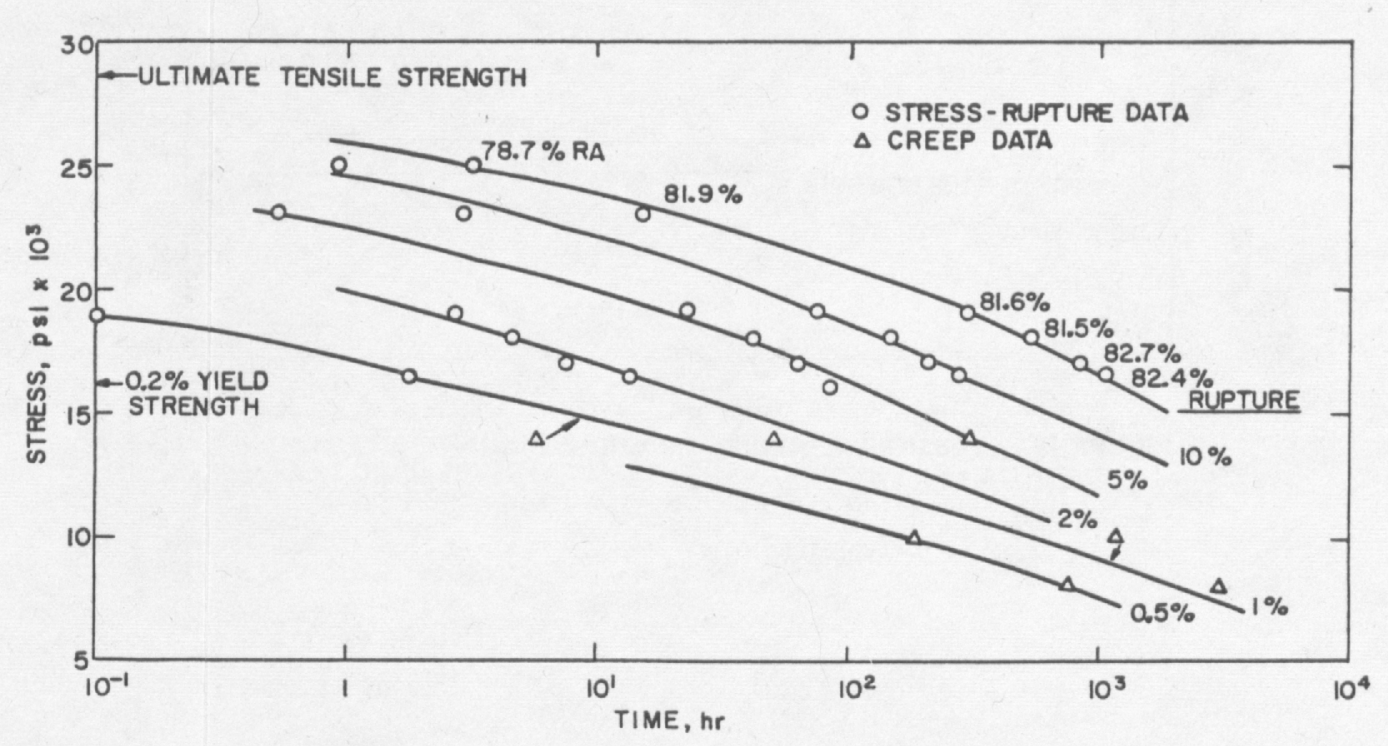

FIGURE 24. STRESS REQUIRED FOR VARRIOUS AMOUNTS OF TOTAL DEF ORMATION FOR ZIRCALOY-2

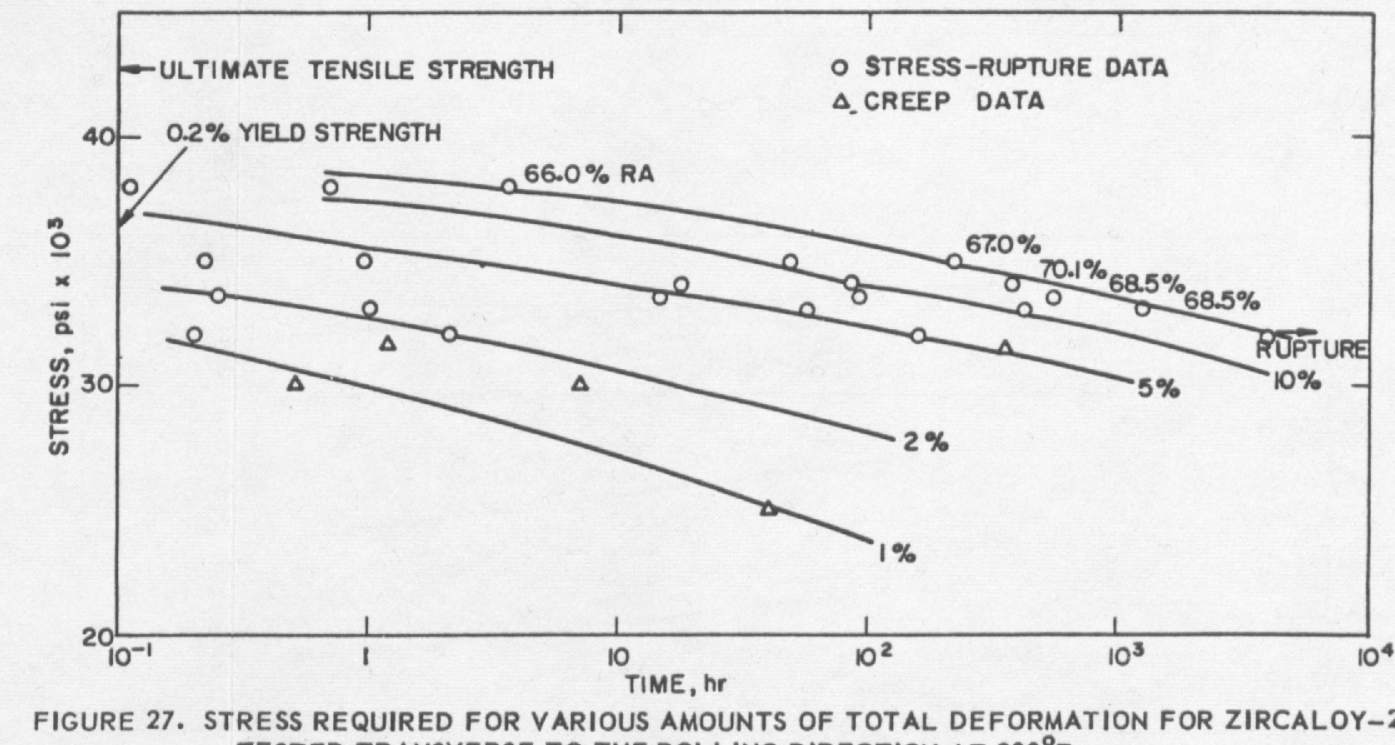

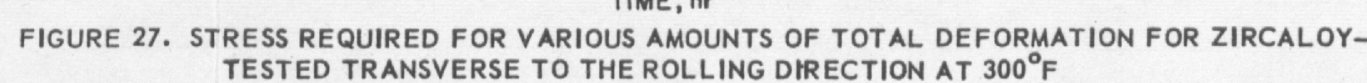




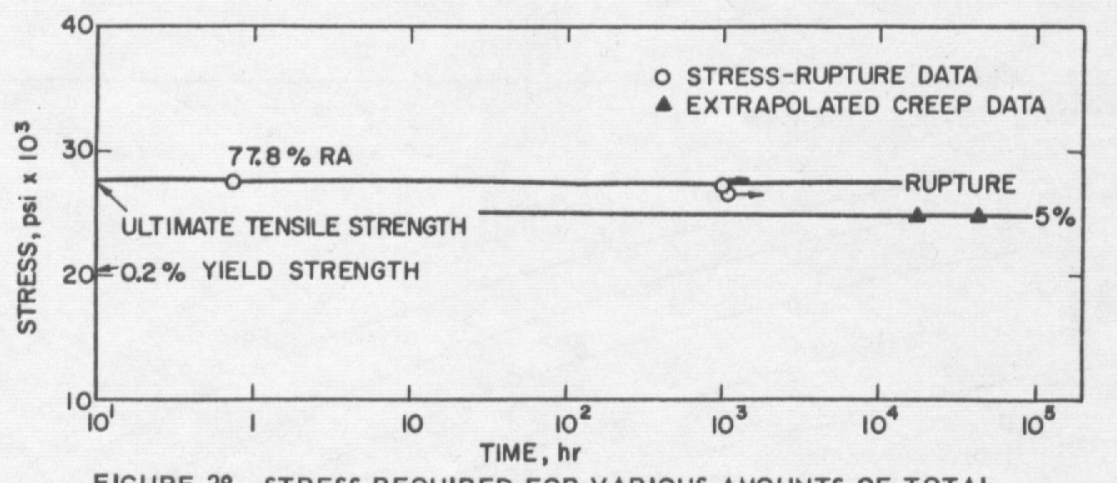

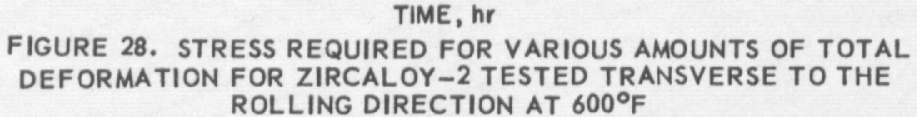

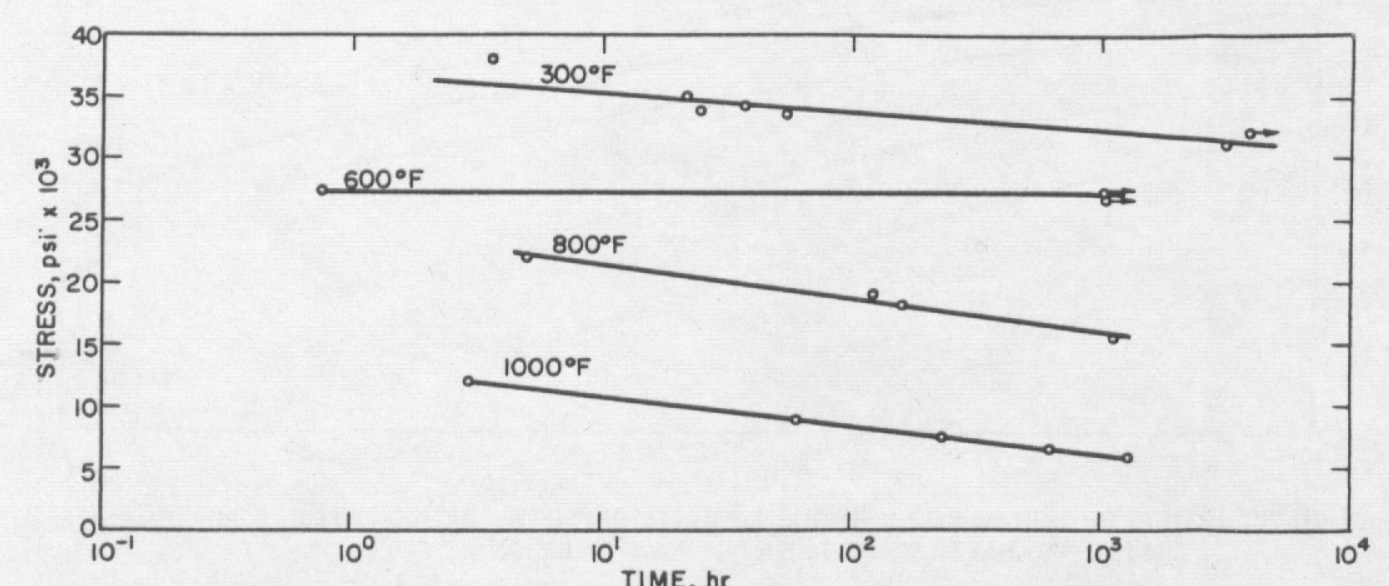

FIGURE 31. RUPTURE STRENGTH OF ZIRCALOY-2 TESTED TRANSVERSE TO THE

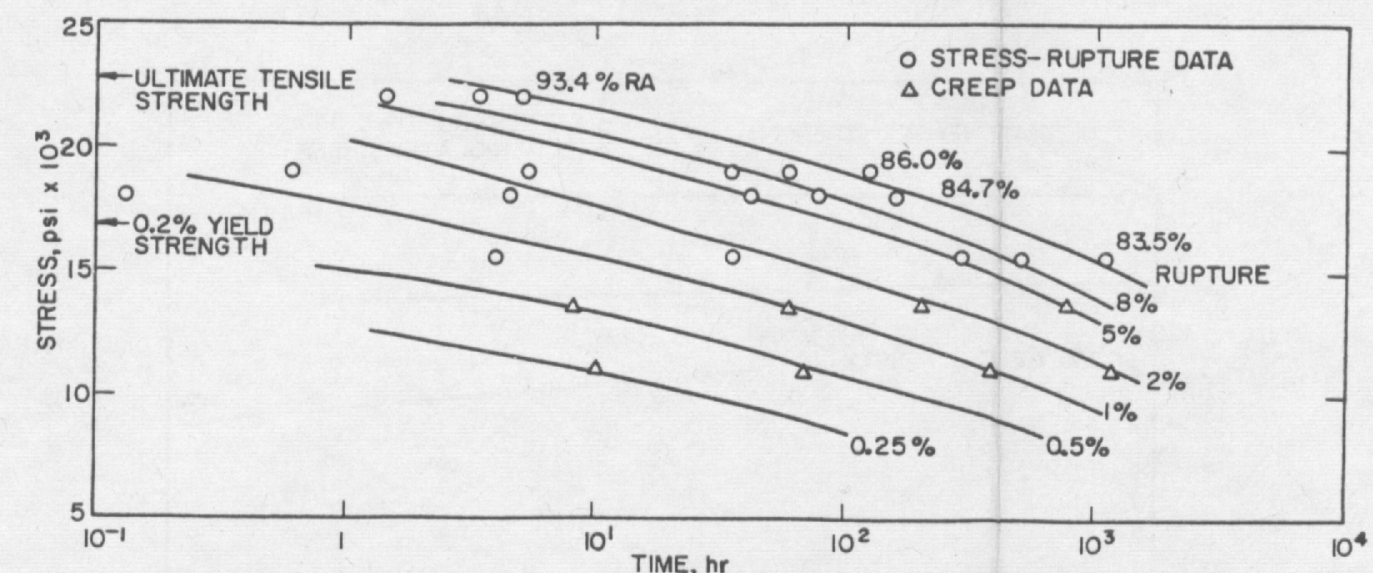

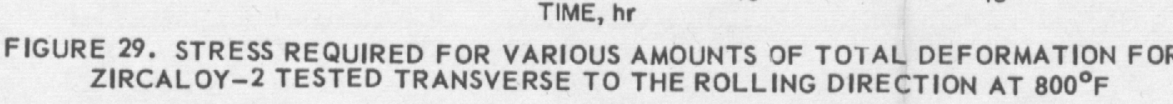

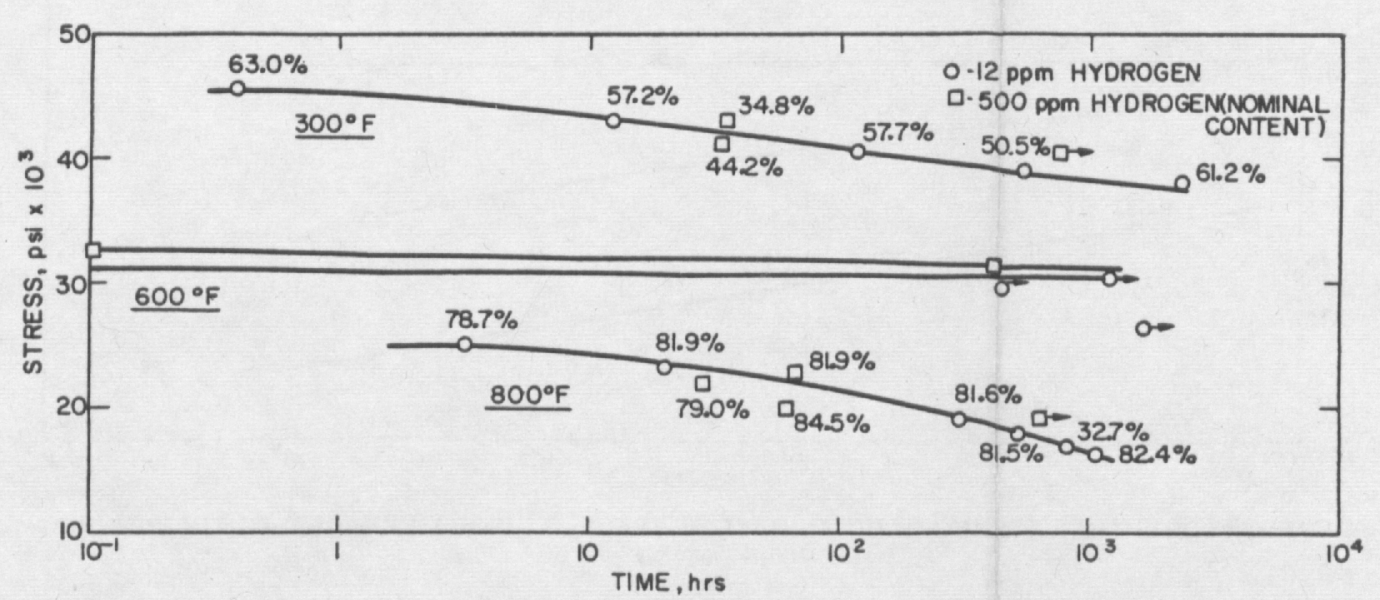

TIME, hrs
FIGURE 32 . EFFECT OF 500 PPM HYDROGEN ON RUPTURE STRENGTH AND DUCTILITY AT THREE
TEMPERATURES FOR ZIRCALOY-2 TESTED LONGITUDINALLY TO THE ROLLING DIRECTION

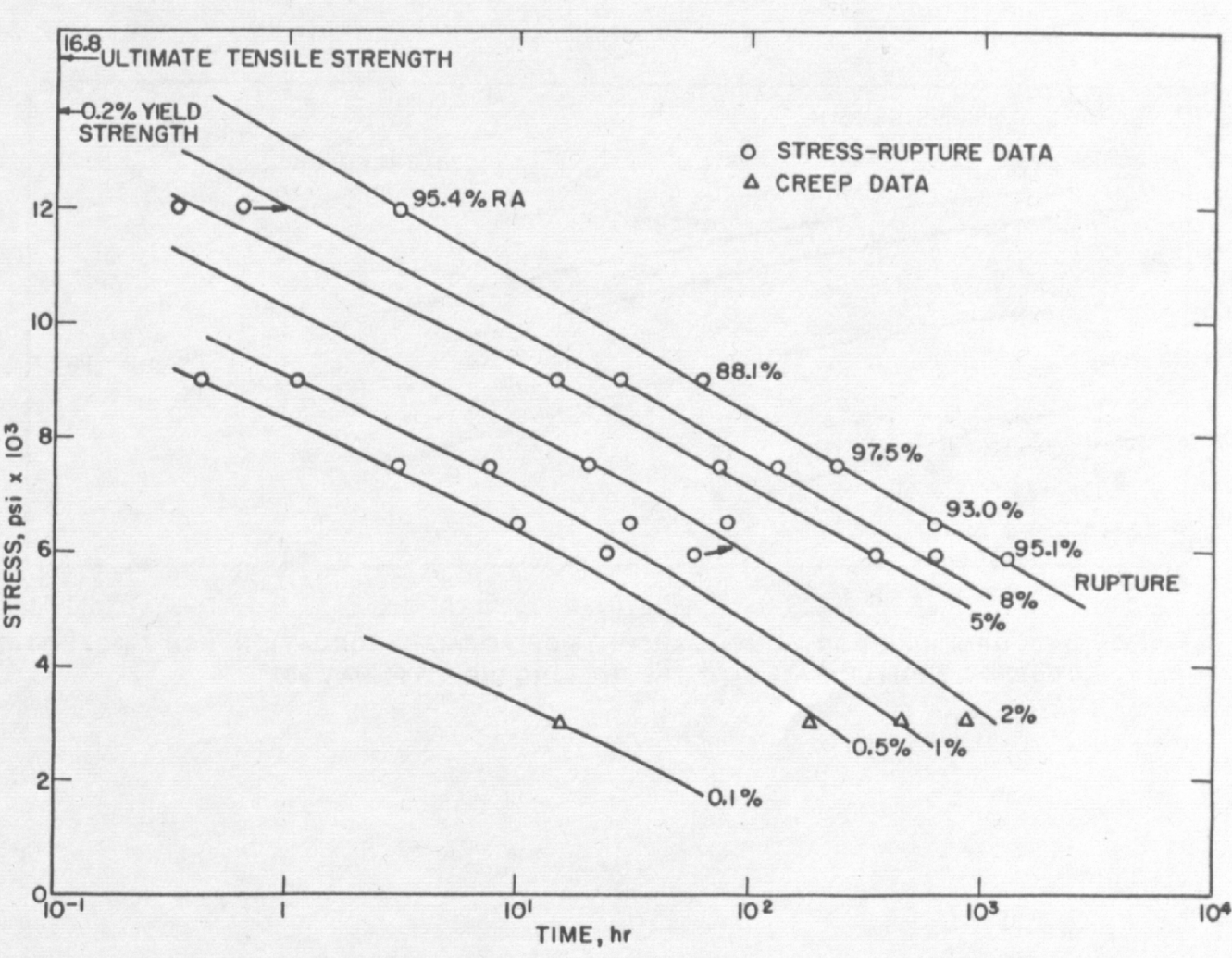

FILURE 30. STRESS REQUIRED FOR VARIOUS AMOUNTS OF TOTAL DEEORMATION FOR
ZIRCALOY-2 TESTED TRANSVERSE TO THE ROLLING DIRECTION AT MOOO

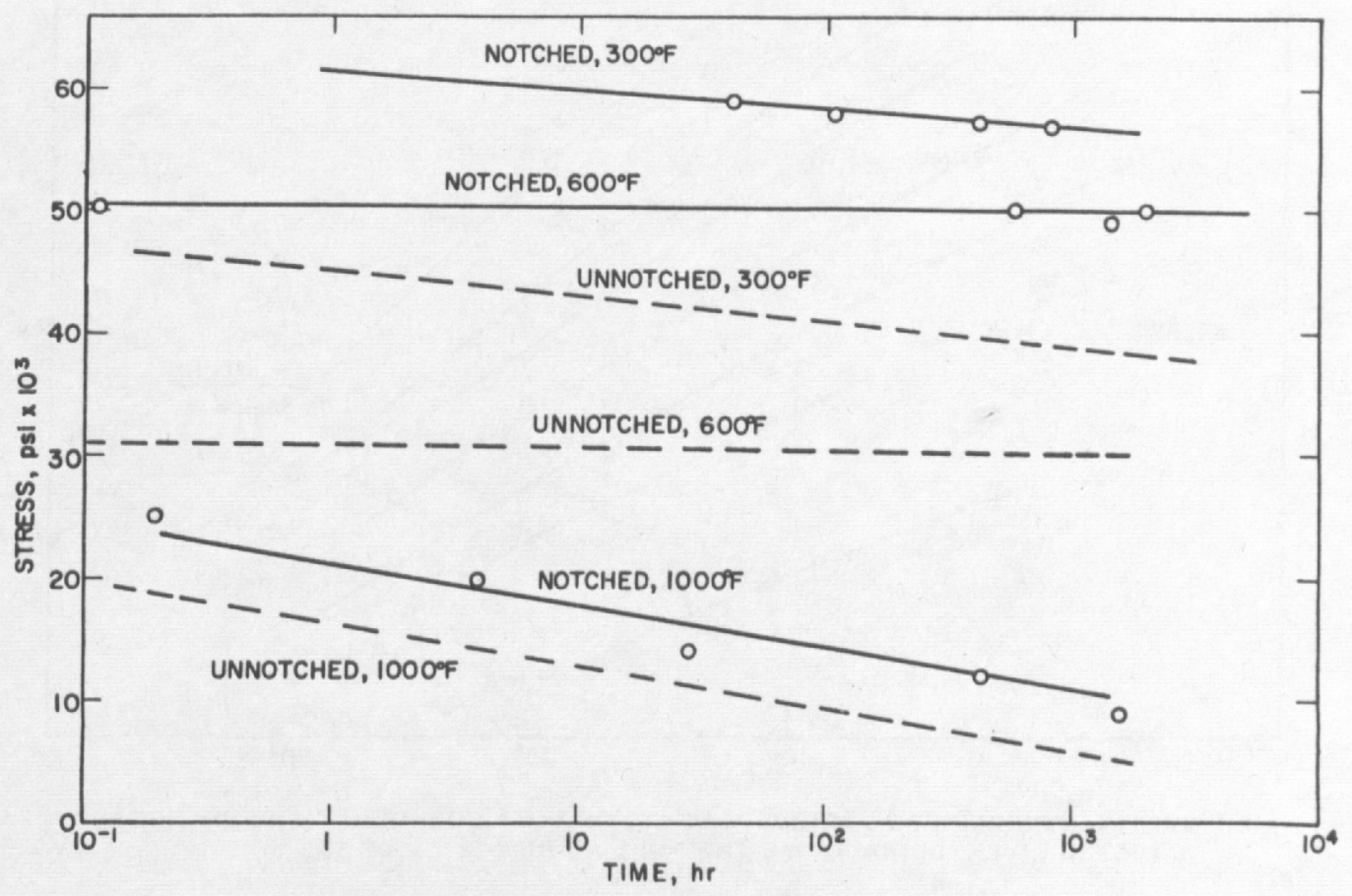

FIGURE 33. RUPTURE STRENGTH OF NOTCHED AND UNNOTCHED IRCALOY-2 TESTED 
TABLS 14. SLAMARY OF FATIQUE TESTS PIRRPORUED ON ZIRCALOY-2

\begin{tabular}{|c|c|c|c|c|c|c|}
\hline \multirow[b]{3}{*}{$\begin{array}{l}\text { Teat Temperature, } \\
\text { OF }\end{array}$} & \multirow[b]{3}{*}{$\begin{array}{c}\text { Notah } \\
\text { Condition }\end{array}$} & \multirow[b]{3}{*}{ Orain S1ze } & \multicolumn{4}{|c|}{ DAreotion } \\
\hline & & & \multicolumn{2}{|c|}{ Longitudingl } & \multicolumn{2}{|c|}{ Transyerse } \\
\hline & & & $\frac{\text { Hydrogen }}{12}$ & $\frac{\text { Content, } \mathrm{ppm}}{500}$ & $\frac{\text { Hydrogen }}{12}$ & $\frac{\text { Content, ppm }}{500}$ \\
\hline \multirow[t]{4}{*}{77} & Unnotahed & Normal & 10 & 6 & 10 & - \\
\hline & & Large & - & - & - & - \\
\hline & Notahed & Normal & 6 & 6 & - & - \\
\hline & & Large & - & - & - & - \\
\hline \multirow[t]{4}{*}{600} & Unnotahed & Normal & 8 & 5 & 7 & - \\
\hline & & Large & - & - & - & - \\
\hline & Notahed & Normal & 5 & - & - & - \\
\hline & & Large & 3 & - & - & - \\
\hline \multirow[t]{4}{*}{900} & Unnotched & Normal & 8 & - & 6 & - \\
\hline & & Largo & - & - & - & - \\
\hline & Notahed & Normal & - & - & - & - \\
\hline & & Large & - & - & - & - \\
\hline
\end{tabular}

the strain was equal in both the tension and compression directions. The data are reported as either strain or stress renge versus number of cycles, 1.e., the peak-to-peak variation in measured strain or measured stress. It must be emphasized that the stress range data are not related in any simple manner to the strain range data because of hysteresis effects. It is not the "fictitious elastic stress" used by designers in fatigue analysis.

Table 14 shows the number of specimens tested with respect to the variables involved: temperature, directionality, grain size, hydrogen content, and notches. The data are presented in Figures 34 to 41 . . From these graphs, the following observations may be made:

1. The fatigue strength of the transverse specimen is lower than that of the longitudinal specimen. This effect decreases with increasing temperature. Very roughly, at equal strain ranges the longitudinal specimens have three times the life of transverse specimens at room temperature, two times the Iife at $600^{\circ} \mathrm{F}$, and at $900 \% \mathrm{~F}$ the two specimens are about equivalent.

2. The presence of $500 \mathrm{ppm}$ hydrogen in unnotched specimens results in a small but measurable reduction of the strain range required for failure at room temperature. The effect is about one-half that caused by directionality. Hydrogen has no effect at $600 \%$. Hydrogen also has no effect on the notch fatigue properties. 
TABLE 15. NOTCH SENSITIVITY FACTOR OF ZIRCALOY-2 TESTED IN THE LONGITUDINAL DIRECTION TO ROLLING

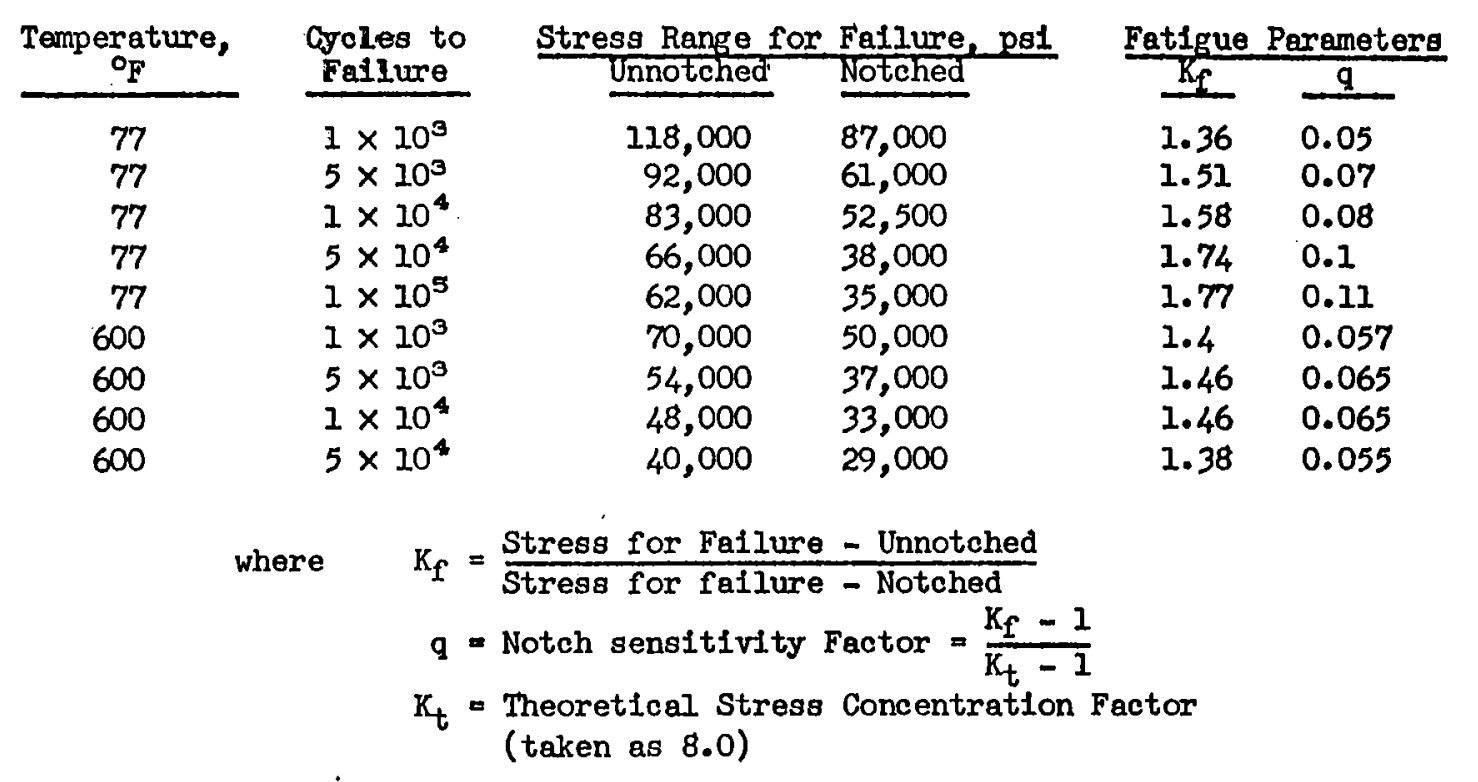

3. The notch sensitivity factor (defined in Table 15) is quite low. Its value at room temperature and $600^{\circ} \mathrm{F}$ at several values of life is shown in Table 15. The highest value of the notch sensitivity factor is only about 0.1 (i.e., when $K_{t}=8, K_{f}$ is only $1.77 \max$ ).

4. The effect of a large grain size lowers the notched fatigue strength at $600 \%$. Because no unnotched specimens were tested with a large grain size, it is not possible to state precisely what the notch sensitivity factor is for the large grain size case. It is not anticipated that it would increase greatly over that obtained for the small grain size (see Discussion). 


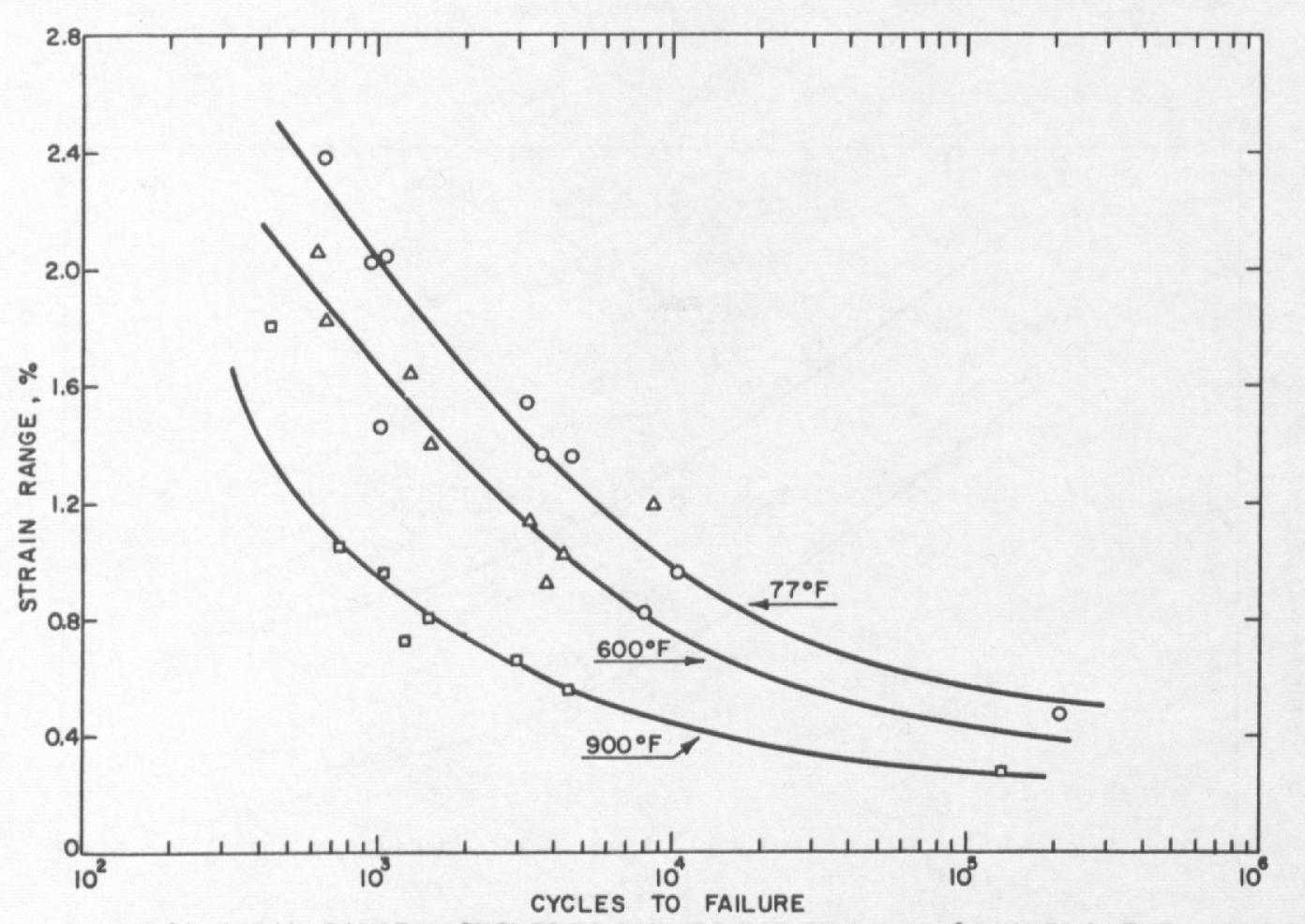

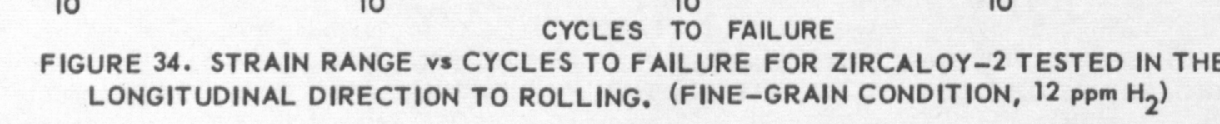

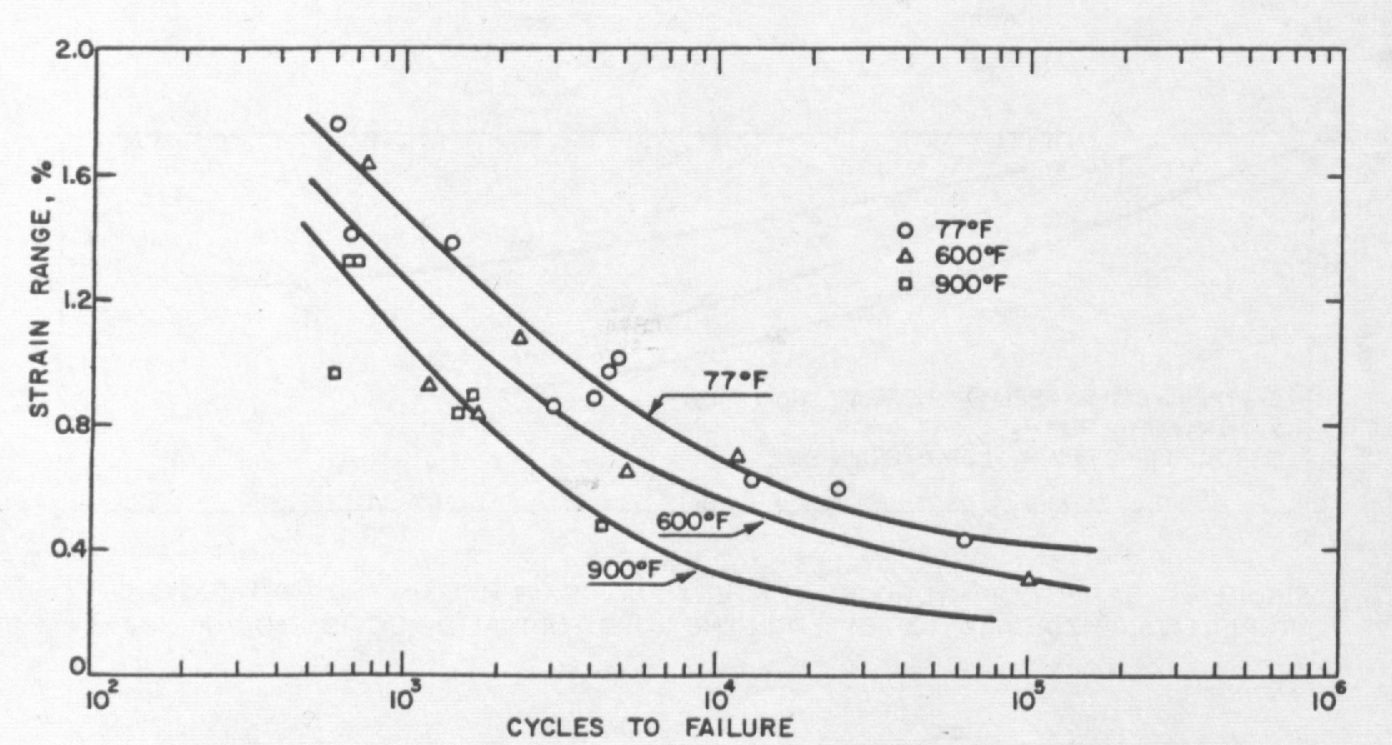

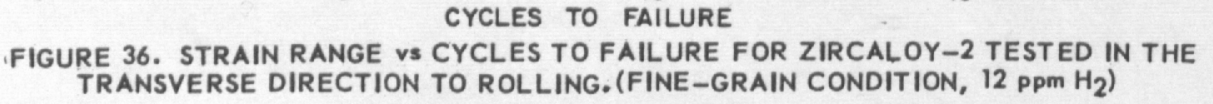

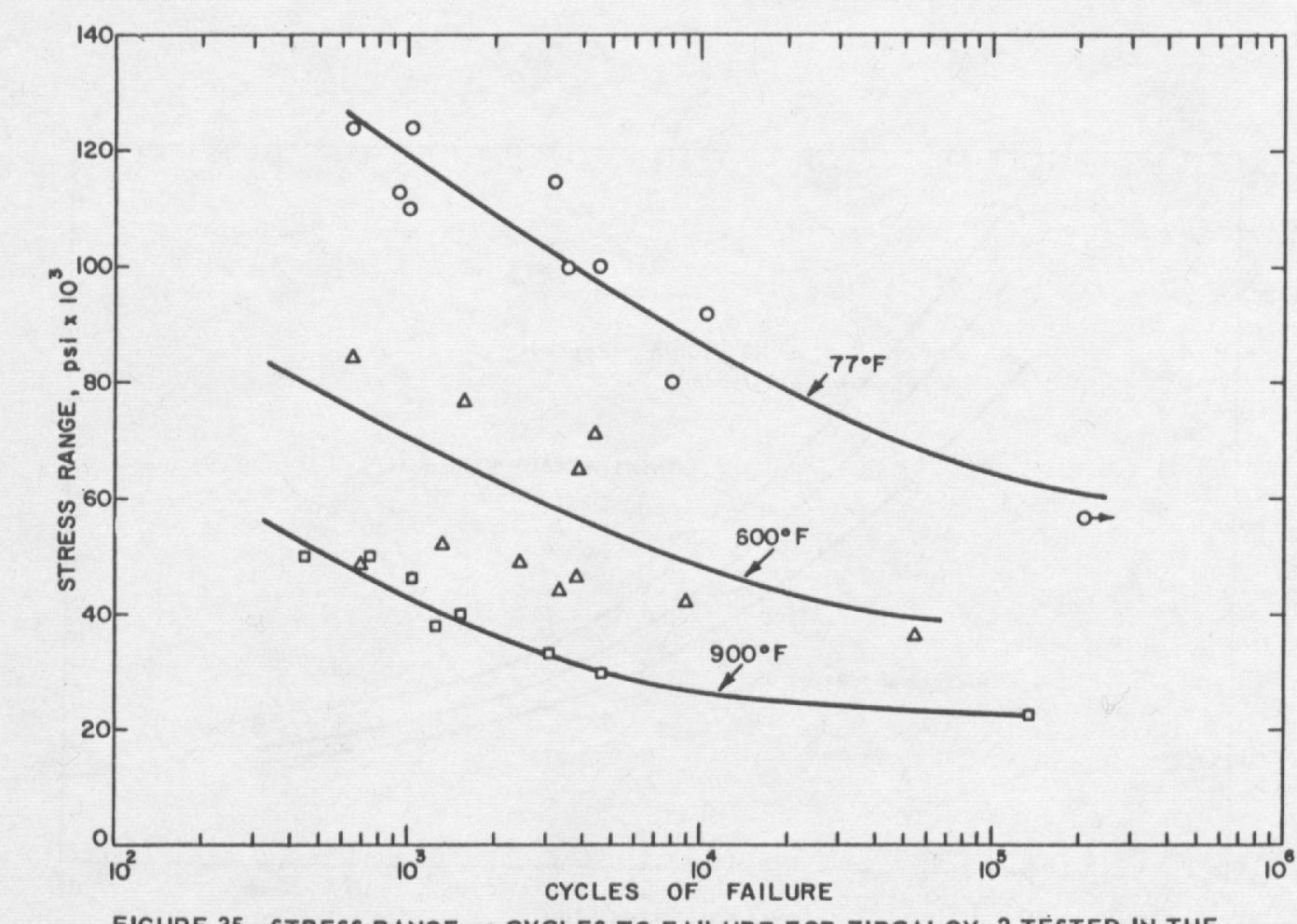

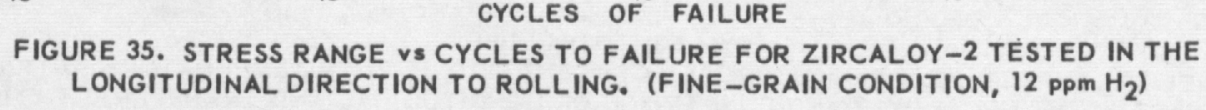

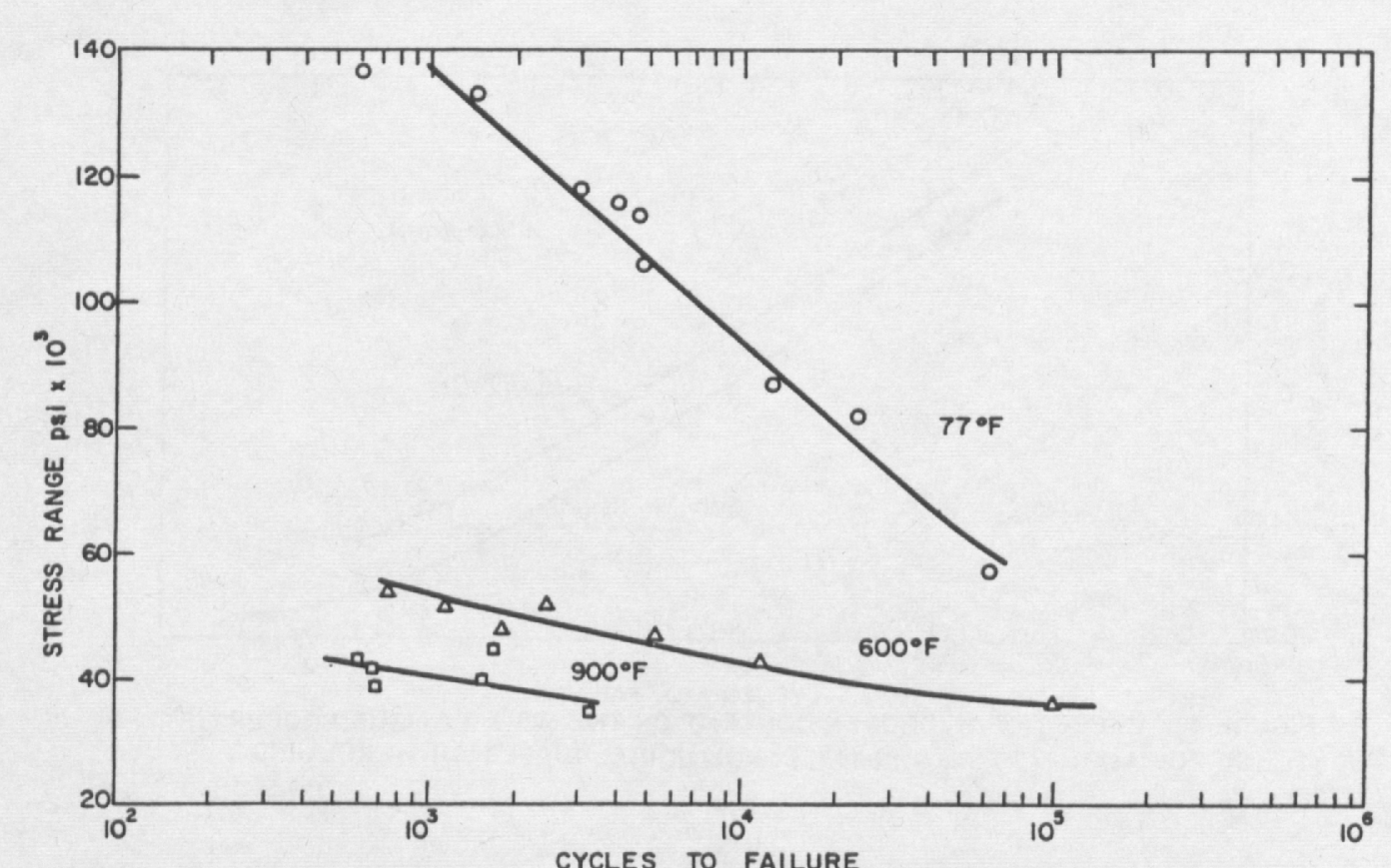

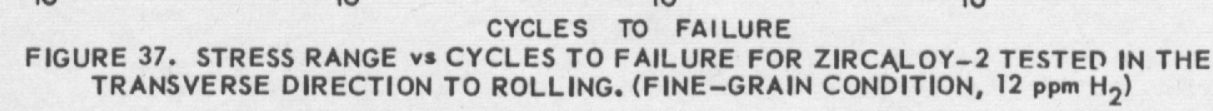




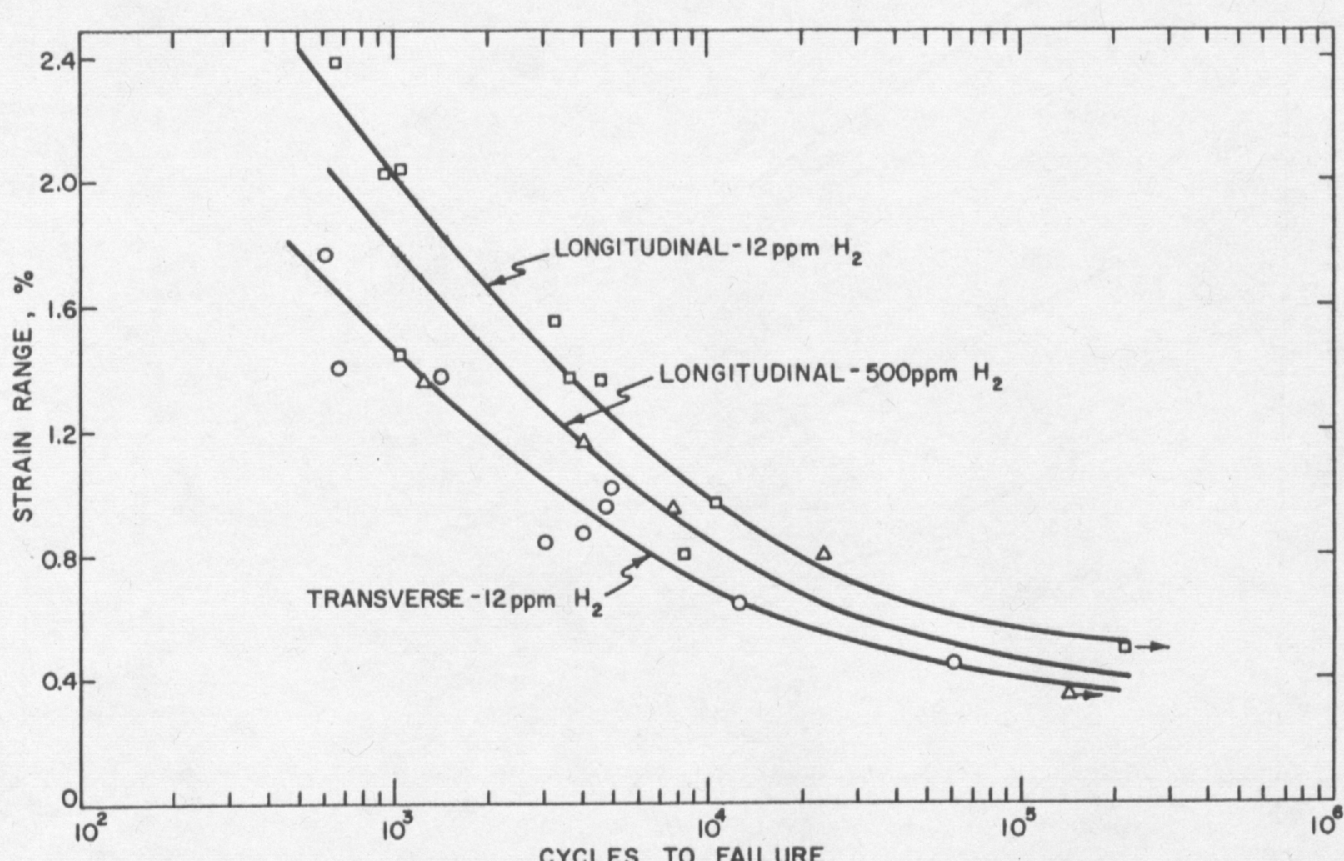

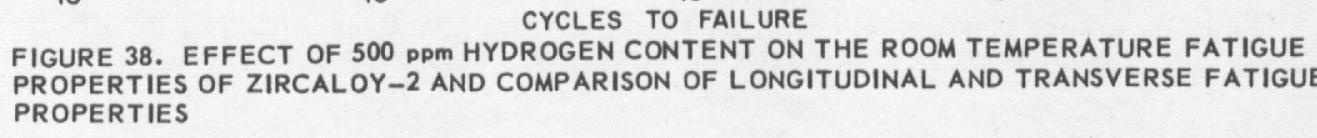

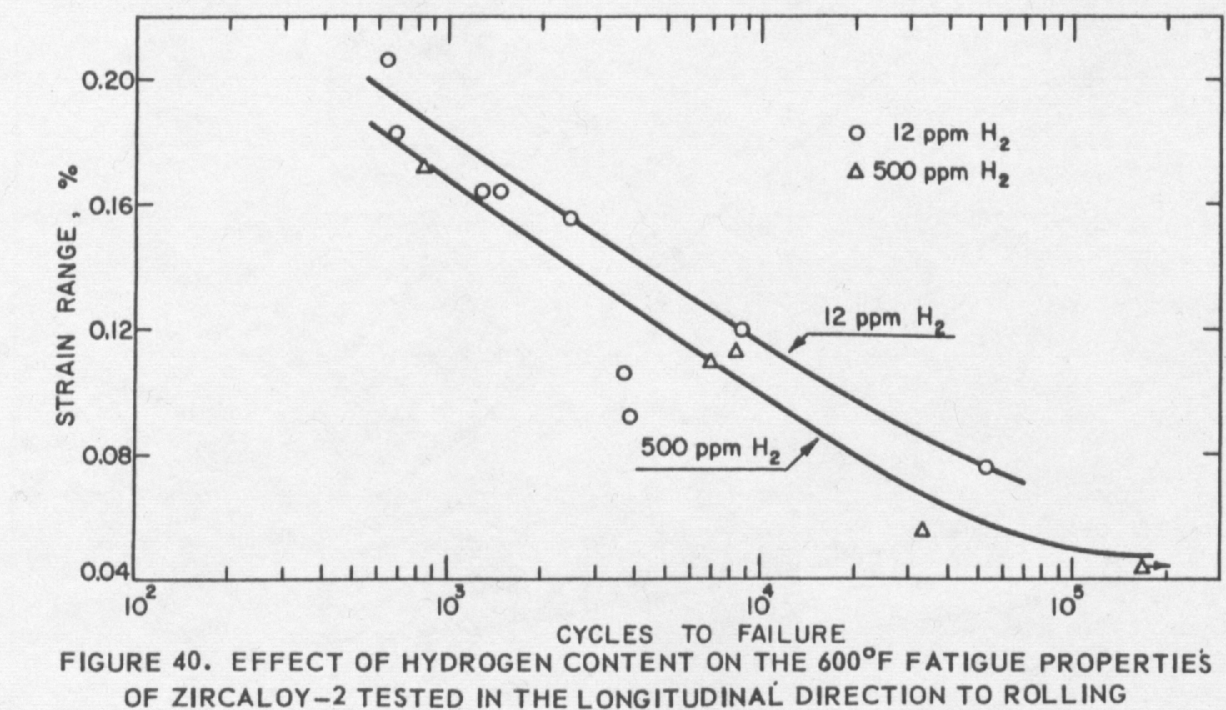

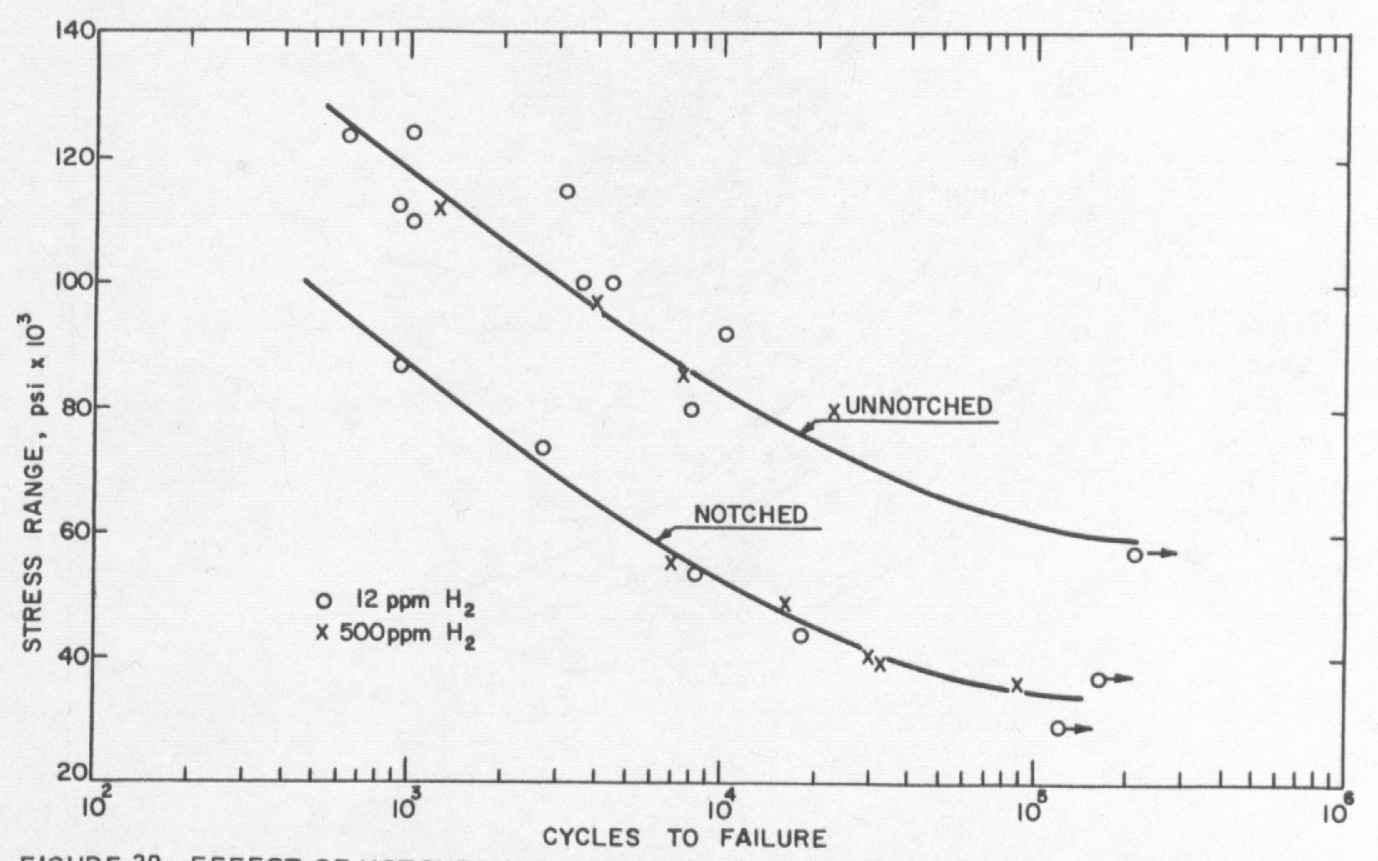

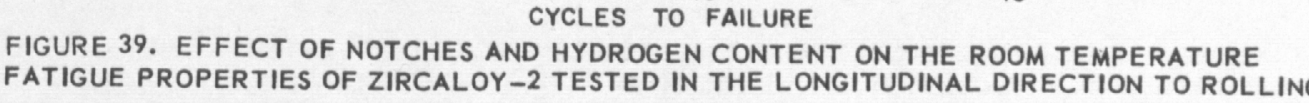

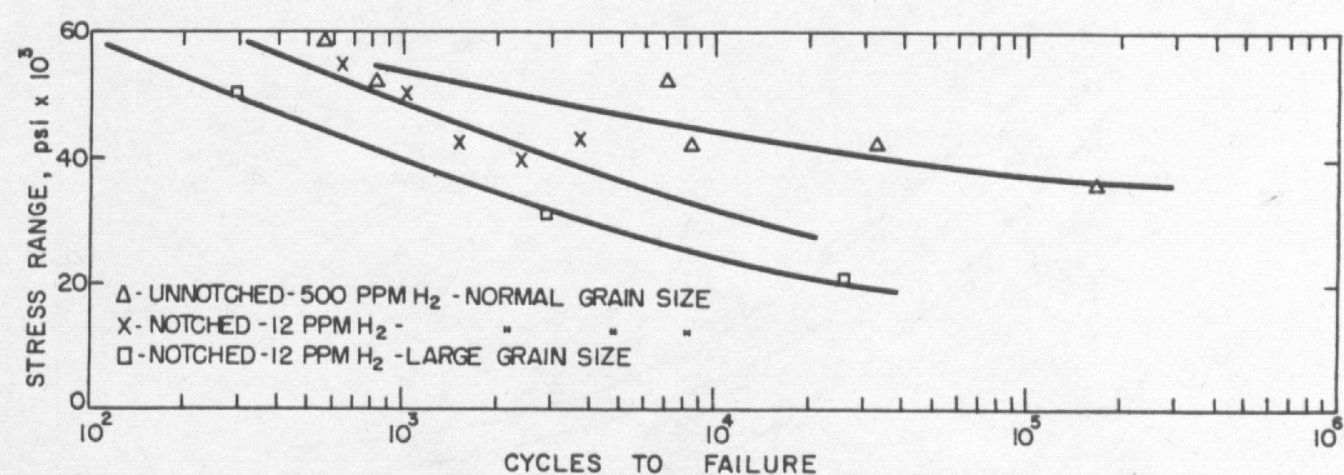

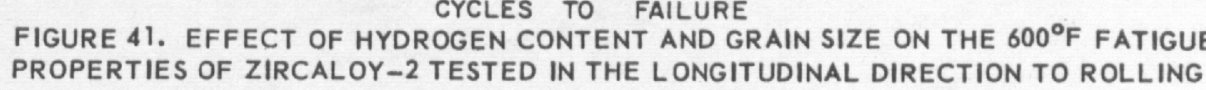


DISCUSSION

The results obtained for the coefficient of thermal expansion and the elastic modulus are fairly straightforward. The anisotropic characteristics of Zircaloy-2 manifest themselves in different values of the coefficient of thermal expansion when the material is tested in the three principle directions to rolling. This has been shown to be true for zirconium. ${ }^{14}$ The elastic modulus, however, does not reflect the anisotropic behavior of Zircaloy-2, at least at room temperature and in the longitudinal and transverse direction to rolling.

One question may be raised in connection with the work performed to determine the coefficient of thermal expansion. Figure 10 shows a particular dilatometric curve of a longitudinal specimen taken through the phase transformation. Associated with the transformation is a "plateau," where the specimen apparently changes in length isothermally. This effect has been noted in work performed by J. Intrator. ${ }^{15} \mathrm{He}$ speculated that this behavior may be caused by a reaction involving iron, nickel, and chromium, and furthermore that it is diffusion controlled because it can be suppressed by increasing the heating rate.

Before discussing the tensile, creep, and fatigue results where hydrogen was a test variable, it is necessary to say something about the accuracy of the specimen hydriding process and the effect of long times at temperatures on hydrogen content. Because of the large number of specimens that had to be hydrided, it was imperative that batch hydriding be used. Approximately six specimens constituted an individual batch. When batch hydriding is performed, there exists the distinct possibility that different amounts of hydrogen may be introduced into individual specimens because of slightly varying surface conditions. A sufficiently long time at temperature should cause the hydrogen to distribute itself homogeneously throughout the entire specimen. Initial checks performed on the hydriding process indicated that satisfactory distribution of hydrogen was occurring. However, subsequent checks on fractured specimens showed that the hydrogen content varied considerably, with the maximum deviation in the order of $30 \%$. Because of the time and cost involved, it was not feasible to check each specimen after fracture for its hydrogen content. Therefore, the nominal hydrogen contents reported must be considered to have an uncertainty of about $30 \%$ associated with them.

The time at temperature did not seem to affect the hydrogen level appreciably. For example, two stress-rupture specimens with a nominal hydrogen content of $500 \mathrm{ppm}$ had hydrogen levels at $800^{\circ} \mathrm{F}$ of $553 \mathrm{ppm}$ and $608 \mathrm{ppm}$ after 60 and $608 \mathrm{hr}$, respectively. Even if the erratic values due to the batch hydriding process are considered, it seems unlikely that a great deal of hydrogen was lost by diffusion at the temperatures involved. 
If the general effect of hydrogen on mechanical properties is considered, there was no case of a drastic change in properties because of the presence of hydrogen. Reductions in ductility were observed, but the remaining amount of ductility in all cases was still quite large. Very low strain rates, as obtained in the stress-rupture tests, did not lead to any large detrimental effects with hydrogen present. Finally, the effect of hydrogen on fatigue properties is very small, smaller than the effect due to the anisotropic characteristics of the material. It is difficult to escape the conclusion that hydrogen up to $500 \mathrm{ppm}$ distributed uniformly in Zircaloy-2 cannot by itself reduce the ductility to a very low value.

When the results of the tensile and creep tests are compared, an interesting observation is made. As pointed out above under Test Results, Creep and Stress-Rupture Properties, the transverse direction to rolling invariably exhibits lower creep properties than the longitudinal direction. In view of the appreciably higher yield strength in the transverse specimen, this result calls for an explanation.

The explanation lies in the stress-strain curves for the two directions to rollings. An examination of Figure 20 shows that, even though the transverse yield strength is greater than the longitudinal value, at about $1.0 \%$ strain the behavior is reversed. This, then, is probably the explanation of the creep test results. In spite of the higher yield strength of the transverse specimens, after a small amount of plastic flow has occurred, the longitudinal specimen is stronger. This increased strength is reflected in the creep properties.

When the tensile and the creep properties are examined, it is evident that there is some peculiar behavior in the neighborhood of $600^{\circ} \mathrm{F}$. The creep rate is very low, and the tensile strength properties tend to level out at around $600 \circ \mathrm{F}$ when plotted versus temperature. This behavior is believed to be a manifestation of strain aging. Similar effects have been noted in previous work and attributed to the same cause. ${ }^{10}$

The tensile properties show effects that are associated with known strain aging materials, i.e., carbon steel in the "blue-brittle" range. The strength and ductility reversals are not as sharp as they are in the case of carbon steel, nor does the flow curve at the critical temperature display the serrated shape typical of carbon steels in the range of 200 to $500 \% \mathrm{~F}$. However, the absence in Zircaloy-2 of a serrated flow curve is not necessarily evidence against a strain aging effect, since it has been shown that these effects are much less pronounced in some metals than in others and may appear under experimental conditions 


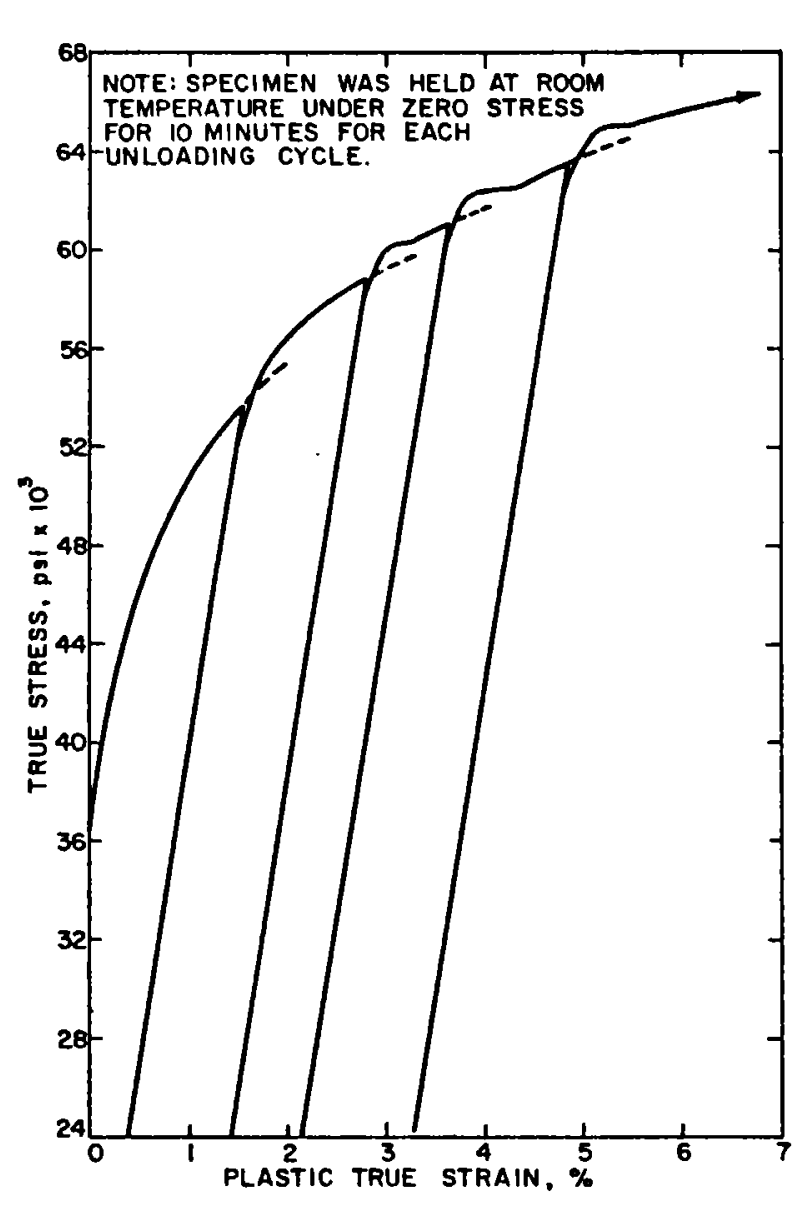

that are not commonly investigated. ${ }^{17}$ The low creep behevior at $600^{\circ} \mathrm{F}^{*}$ is also typical of strain aging materials at the temperature at which aging takes place.

J. D. Lubahn ${ }^{17}$ has shown that the rate sensitivity, when plotted versus temperature, shows a minimum when strain aging occurs. This effect is also shown in Figure 21, where the rate sensitivity obtained from tensile data is plotted versus temperature. The minimum occurs at $800 \%$, which suggests that the strain aging effect is present over a fairly wide range of temperatures.

A strain aging material should show an upward displacement of the tensile flow curve and a yleld point when the material has been given an intermupted tensile test and allowed to age for a short time before reloading. ${ }^{18}$ To check this behavior, a preliminary interrupted FIGURE 42. INTERRUPTED STRESS-STRAIN CURVE FOR tensile test at room temperature ZIRCALOY-2 AT ROOM TEMPERATURE LLNGITUIINAL DIRECTION TO ROLLING) was performed. The curve obtained is shown in Figure 42. Each interruption was followed by a $10-\mathrm{min}$ aging time at room temperature. The data show that the yield point increases after aging and that there is a tendency for a drop in load to appear. All the facts, then, seem to point to the presence of a strain aging phenomenon in Zircaloy-2.

Caution must be exercised when applying the effects noted for this particular lot of material to other ingots of zircaloy-2. For example, there are data ${ }^{19}$ on extruded Zircaloy-2 which do not exhibit a very low creep rate at $600 \%$. Presumably, the element (or elements) responsible for strain aging can be present in varying amounts and produce differing degrees of strain aging.

When the fatigue properties of Zircaloy-2 in the longitudinal and transverse directions to rolling are examined, it is observed that the

${ }^{*}$ A small number of exploratory tests showed that the abnormally low creep rates existed at least between 500 and $650 \%$. 
transverse fatigue strength is lower than the longitudinal fatigue strength. There are at least two possible reasons for this behavior. In steels that have a laminated type of structure the fatigue strength is lower in the transverse direction than in the longitudinal. 20 Zircaloy-2, in general, shows some stringering in the direction of rolling which corresponds in kind, if not in degree, to the behavior of a laminated structure. This, then, is a possible reason for the lower transverse fatigue properties.

Another explanation can be advanced for the directionality effect. The fatigue properties of a material in low-cycle fatigue are, in part, dependent on the size and shape of the hysteresis loop developed after the material has "shaken down." The area of the loop is a measure of the energy absorbed during a cycle. The transverse direction, because of its flatter stress-strain curve, may be expected to develop a wider hysteresis loop than the longitudinal direction. This also may be a reason for the lower transverse fatigue values. It should be pointed out that the failure phenomenon in fatigue is quite complex and not yet understood, and the reason for the differing fatigue properties in the two directions to rolling may well be more complex than either of the explanations advanced above.

In connection with the effect of grain size and notches on fatigue, it has been shown in previous work on alpha-brass ${ }^{21}$ and mild steel, 22 that a large grain size has a detrimental effect on fatigue life. In the case of alpha-brass, however, the notch sensitivity, $q$, decreases as the grain size increases. Because no unnotched specimens of large grain size were fatigue-tested (because of curtailment of the testing program), it was not possible to determine directly the effect of grain size on unnotched fatigue strength. However, by using the values of $q$ found for the small grain size and applying them to the large-grained material, a conservative figure for the notch sensitivity for largegrained material is obtained, based on the results obtained on alphabrass. 


\section{REFERENCES}

1. F. Forscher, "Strain-Induced Porosity and Hydrogen Embrittlement in Zirconium," AIME Trans. (J. Metals) May 1956, 536-543.

2. F. R. Shober et al., "The Mechanical Properties of Zirconium and Zircaloy-2," BMI-1168, February 18, 1957.

3. D. E. Thomas and F. Forscher, "Properties of Zircaloy-2," J. Metals, May 1956, 640-645.

4. W. L. Mudge and F. Forscher, "Mechanical Properties of Zircaloy-2," WAPD-101, July 23, 1954.

5. K. M. Goldman and D. E. Thomas, "Properties of Zircaloy-2," WAPD-T-43, June 3, 1953.

6. American Society for Metals, Atom Movements, Cleveland: ASM, 1951, 233.

7. A. Q. Mowbray, "The Effect of Superposition of Stress Raisers on Members Subjected to Static or Repeated Loads," Proc. SESA 10 No. 2 (1953) 153.

8. G. L. Cutler, "The Universal Precision Dilatometer," KAPL-M-GLC-2, April 23, 1958.

9. R. K. McGeary and B. Lustman, "Preferred Orientation in Zirconium," Trans. ATME 191 (1951) 994.

10. J. P. DenHartog, Mechanical Vibrations, New York: McGraw Hill, 1947, 193.

11. J. J. Richards, "An Evaluation of Several Static and Dynamic Methods for Determining Elastic Moduli," ASTM Spec. Tech.Pub.No. 129, Symposium on Determination of Elastic Constants, June 1952, Philadelphia, 1952, 71-96.

12. J. R. Low, Jr., "Direct Loading of Materials," Am. Soc. for Metals, Properties of Metals in Materials Engineering, Cleveland: ASM 1949, 35.

13. E. E. Baldwin, G. J. Sokol, and L. F. Coffin, "Cyclic Strain Fatigue Studies on AISI Type 347 Stainless Steel," Proc. ASTM 57 (1957) 567-586.

14. R. K. McGeary and B. Iustman, op. cit.

15. J. Intrater, "Dilatometric Investigation of Vacuum-Melted Zircaloy-2," Zirconium Highlights, WAPD-ZH-1, November 1957.

16. W. L. Mudge and F. Forscher, op. cit.

17. J. D. Iubahn, "Strain Aging Effects," Trans. ASM 44 (1952) 643-666. 
18. H. S. Schwartzbart and J. R. Low, "The Yielding and Strain-Aging of Carburized and Nitrided Single Crystals of Iron," Trans. ASME 185 (1949) 637-645.

19. R. L. Mehan and F. W. Wiesinger, "Interim Report on the Creep Rupture Properties of Extruded and Annealed Zircaloy-2," Zirconium Highlights, WAPD-ZH-6, April 1958.

20. R. Cazaud, Fatigue of Metals, New York: Phil. Lib., 1953, 437.

21. Am. Soc. for Metals, Fatigue, Cleveland: ASM, 1954, 24.

22. R. Cazaud, op. cit., 101.

23. A. L. Austin and R. F. Steidel, "The Tensile Properties of Some Engineering Materials at High Rates of Strain," ASTM Proc. 59, 1959, 1292-1306.

24. G. Sachs and J. D. Lubahn, "Notched Bar Tensile Testing on HeatTreated Low Alloy Steels," Trans. ASM 21 (1943) 125-160.

25. B. Lustman and F. Kerze, Jr. (ed.) The Metallurgy of Zirconium, New York: McGraw Hill, 15th ed., 1955, 409. 


\section{APPENDIX A}

EFFECT OF HEAT TREATMENT AND STRAIN RATE ON THE TENSILE PROPERTIES OF ZIRCALOY -2

In addition to the major variables studied in this investigation, a limited amount of tensile testing was performed to determine the effects of various types of heat treatment on the tensile properties of Zircaloy-2. The need for studying various types of heat treatment arose because certain components in which zircaloy-2 is utilized may be heat treated above the phase transformation (about $820^{\circ} \mathrm{C}$ ). Moderate changes in strain rate were also studied at room temperature. The effect of strain rate is important because it gives an indication of the behavior of the material under certain types of shock loading.

The tests were performed at room temperature or at $600^{\circ} \mathrm{F}$ in an Instron machine. The ranges of rate investigated were limited by the rate capacity of the testing machine, which is $20 \mathrm{in.} / \mathrm{min}$ cross-head speed. Three head motions were used, i.e., 0.02 in./min, $2 \mathrm{in./min,}$ and $20 \mathrm{in./min.} \mathrm{With} \mathrm{a} \mathrm{1.1-in.} \mathrm{gage} \mathrm{length,} \mathrm{the} \mathrm{corresponding} \mathrm{values}$ of strain rate are $0.0182 / \mathrm{min}, 1.82 / \mathrm{min}$, and $18.2 / \mathrm{min}$. These values of strain rate are not precise, as the conversion from cross-head motion to strain rate is a function of the stiffness of the testing machine. However, the values should be accurate enough to serve as a basis for conclusions on the effect of strain rate on tensile properties.

Three types of heat-treatment were employed: below the phase transformation ( $\alpha$ structure), in the phase transformation (mixed $\alpha$ and $\beta$ structure), and above the phase transformation ( $\beta$ structure). With each type of structure obtained: $\alpha$, transformed $\alpha+\beta$, or transformed $\beta$, several grain sizes were obtained. Grain growth below the phase transformation was achieved by critical straining followed by heat-treatment. A similar treatment was used in the mixed $\alpha+\beta$ range. For the intermediate grain size studied, a larger amount of strain was introduced before annealing, thus producing a finer grain size. Above the phase transformation, grain growth could be obtained by controlling the time at temperature. All the heat treatments were performed in a high-vacuum system $\left(<10^{-5} \mathrm{~mm} \mathrm{Hg}\right)$ and were followed by furnace cooling. The heat treatments and the grain sizes produced are summarized in Table A.1. The $\alpha \rightarrow \beta$ transformation, from dilatometric methods previously described, begins at $825^{\circ} \mathrm{C}$ and is completed at $980^{\circ} \mathrm{C}$. Strictly speaking, therefore, the structure represented by all $\beta$ still has some untransformed $\alpha$-phase present at the $960^{\circ} \mathrm{C}$ annealing temperature, but this amount is quite small. Typical photomicrographs of the structures obtained are show in Figures A.I to A.3. 
TABLE A.1. PROCEDURES USED TO OBTAIN VARIOUS GRAIN SIZES IN ZIRCALOY-2

\begin{tabular}{|c|c|c|c|c|}
\hline $\begin{array}{l}\text { Structure } \\
\text { Produced } \\
\end{array}$ & $\begin{array}{l}\text { ASTM Ferrous } \\
\text { Grain S1ze }\end{array}$ & $\begin{array}{l}\text { \% Strain } \\
\text { Introduced }\end{array}$ & $\begin{array}{l}\text { Annealing } \\
\text { Time, } \mathrm{hr}\end{array}$ & $\begin{array}{c}\text { Annealing } \\
\text { Temperature, } \\
{ }^{\circ} \mathrm{C} \\
\end{array}$ \\
\hline $\begin{array}{c}\alpha \\
\alpha+\beta\end{array}$ & $\begin{array}{l}7-8 \\
7-8\end{array}$ & $\begin{array}{l}\text { None } \\
\text { None }\end{array}$ & $\begin{array}{l}0.5 \\
2\end{array}$ & $\begin{array}{l}750 \\
920\end{array}$ \\
\hline $\begin{array}{c}\alpha \\
\alpha+\beta\end{array}$ & $\begin{array}{l}3-5 \\
3-5\end{array}$ & $\begin{array}{l}6.5 \\
6.5\end{array}$ & $\left\{\begin{array}{l}3 \\
3 \\
2\end{array}\right\}$ & $\left\{\begin{array}{c}805 \\
800 \\
920\end{array}\right\}$ \\
\hline B & $3-5$ & None & 0.18 & 960 \\
\hline $\begin{array}{c}\alpha \\
\alpha+\beta\end{array}$ & $\begin{array}{l}0-2 \\
0-2\end{array}$ & $\begin{array}{l}4 \cdot 3 \\
4 \cdot 3\end{array}$ & $\left\{\begin{array}{c}20 \\
20 \\
2\end{array}\right\}$ & $\begin{array}{c}800 \\
\left\{\begin{array}{l}900 \\
920\end{array}\right\}\end{array}$ \\
\hline B & $0-2$. & None & 1 & 960 \\
\hline
\end{tabular}

The data are plotted in Figures A.4 to A.11. Figures A.4 and A.5 show the effect of strain rate on the strength and ductility* of Zircaloy-2 at room temperature. The strength properties increase moderately with increasing strain rate. The fracture ductility, as shown by the reduction in area, remains about constant. These results are similar to those obtained by A. L. Austin and R. F. Stiedel. ${ }^{23}$ The $\alpha+\beta$ treated material, particularly at large grain size, tends to have both lower strength and lower ductility then that produced by other treatments.

Figures A.6 to A.9 show the effect of grain size versus strength and ductility at room temperature and at $600 \% \mathrm{~F}$. The effects are small, but do show a general decrease in strength and fracture ductility for the $\alpha$ and $\beta$ conditions at room temperature. The $\alpha+\beta$ condition shows no change in strength with grain size at room temperature. At $600 \% \mathrm{~F}$ the same decrease in fracture ductility is noted, but the strength properties are relatively unaffected.

Figure A.10 represents the effect of tensile strength and reduction in area for $\alpha+\beta$ material with ASTM grain size 3 to 5 as a function of strain rate. The nominal ultimate strength in both the notched and unnotched conditions at room and elevated temperatures increases with increasing strain rate. The ductilities for the notched and unnotched conditions remain reasonably constant at room temperature, but at $600^{\circ} \mathrm{F}$ they seem to decrease. The ductility at the highest strain rate at $600 \% \mathrm{~F}$ is still quite large. It should be pointed out that reductions in area

*Only the reduction in area can properly be considered as a fracture ductility criterion. The other parameters are included in the graph only for convenience. 


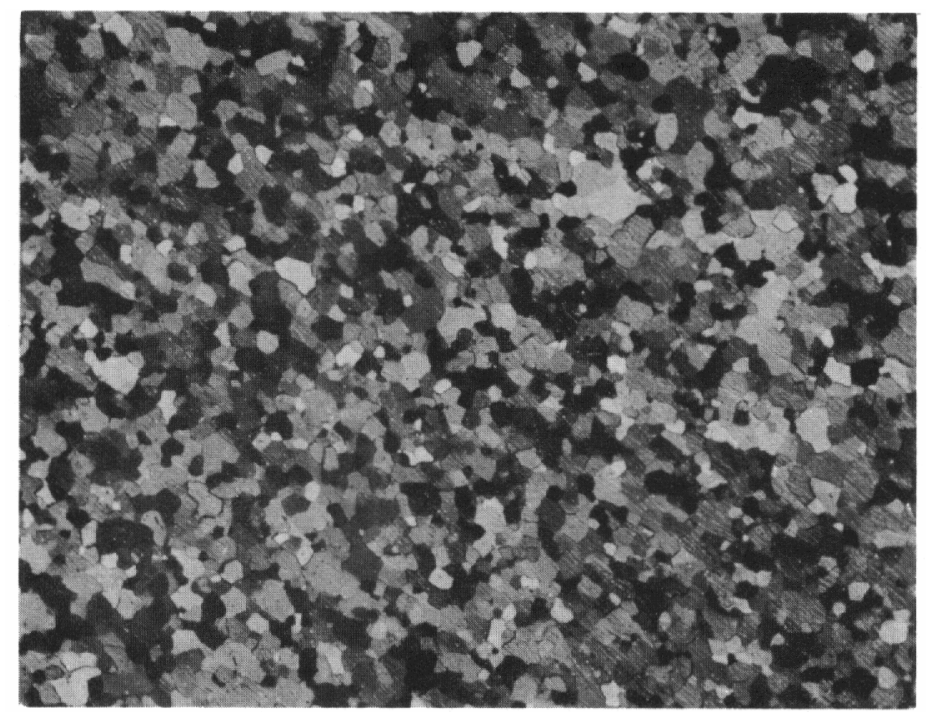

ANNEALING TEMPERATURE: $750^{\circ} \mathrm{C}$ STRUCTURE AT TEMPERATURE: $\alpha$ ASTM GRAIN SIZE: $<8$

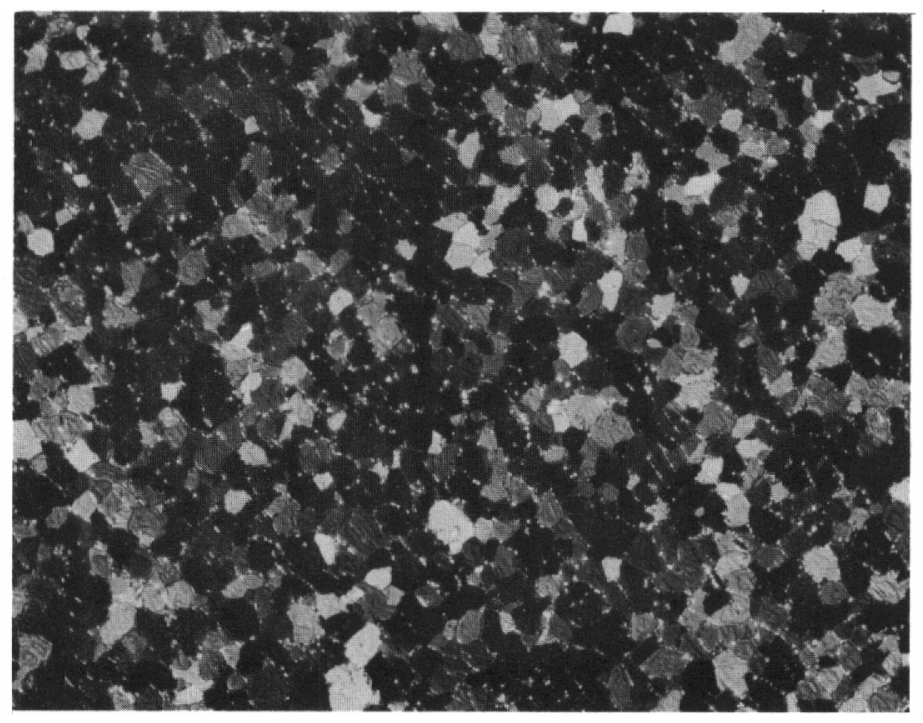

ANNEALING TEMPERATURE: $920^{\circ} \mathrm{C}$ STRUCTURE AT TEMPERATURE: $\alpha+\beta$ ASTM GRAIN SIZE: 7 TO 8

FIGURE A.1. TYPICAL PHOTOMICROGRAPHS OF FINE-GRAIN HEAT-TREATED ZIRCALOY 2. POLARIZED LIGHT 


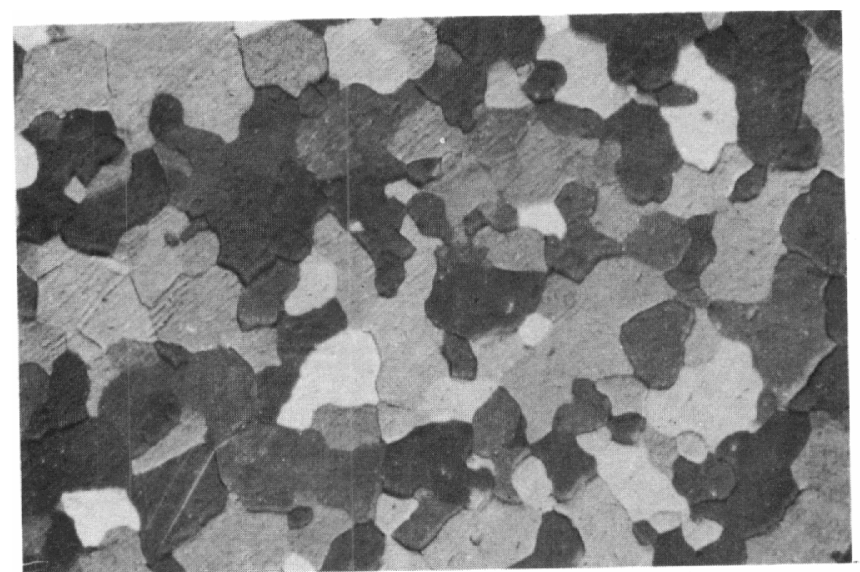

ANNEALING TEMPERATURE: $800^{\circ} \mathrm{C}$ STRUCTURE AT TEMPERATURE: $\alpha$ ASTM GRAIN SIZE: 3 TO 5

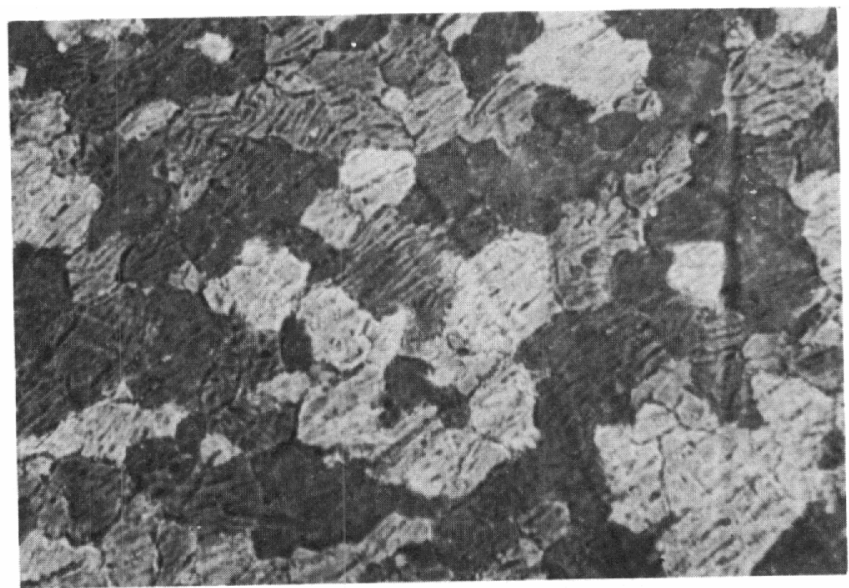

ANNEALING TEMPERATURE: $920^{\circ} \mathrm{C}$ STRUCTURE AT TEMPERATURE: $\alpha+\beta$ ASTM GRAIN SIZE: 3 TO 5

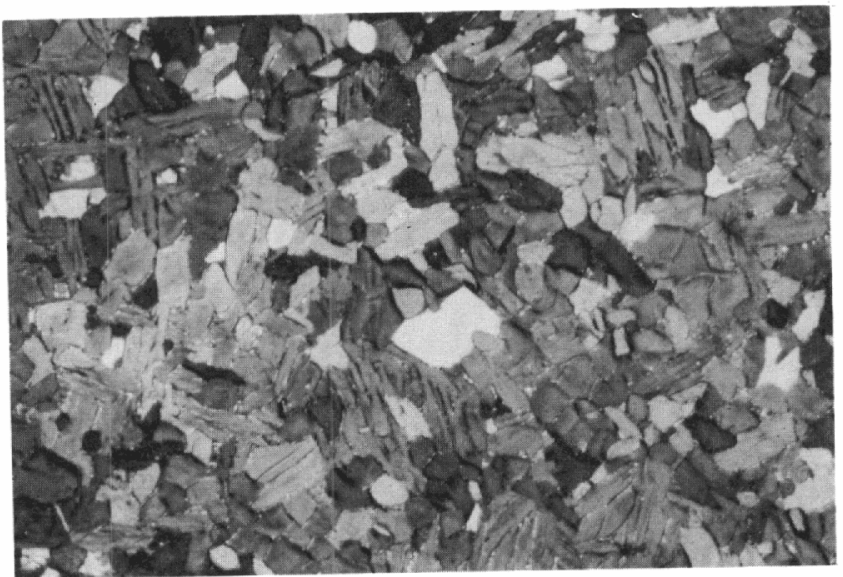

ANNEALING TEMPERATURE: $960^{\circ} \mathrm{C}$ STRUCTURE AT TEMPERATURE: $\beta$ ASTM GRAIN SIZE: 3 TO 5

FIGURE A.2. TYPICAL PHOTOMICROGRAPHS OF INTERMEDIATE-GRAIN HEAT-TREATED ZIRCALOY 2. POLARIZED LIGHT 


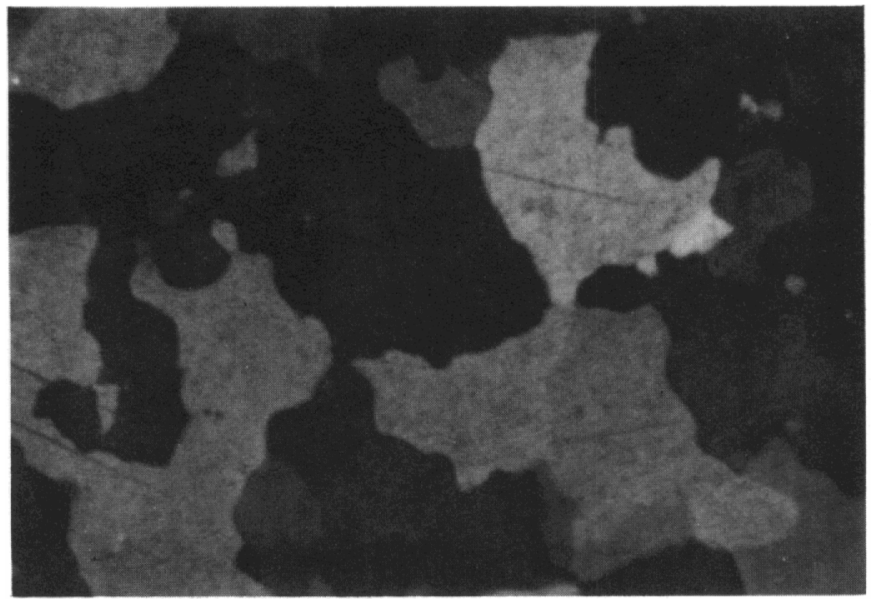

ANNEALING TEMPERATURE: $800^{\circ} \mathrm{C}$ STRUCTURE AT TEMPERATURE: $\alpha$ ASTM GRAIN SIZE: 0 TO 2

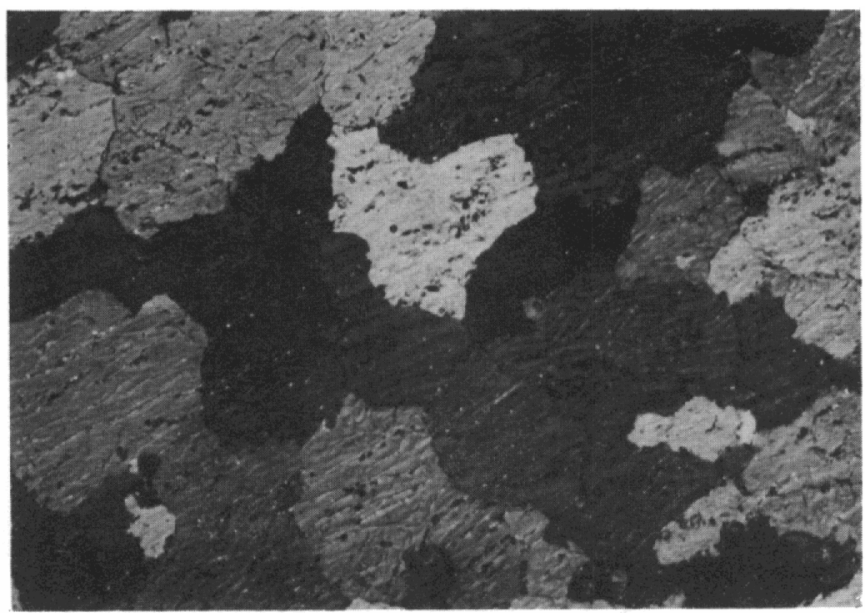

ANNEAL ING TEMPERATURE: $920^{\circ} \mathrm{C}$ STRUCTURE AT TEMPERATURE: $\alpha+\beta$ ASTM GRAIN SIZE: 0 TO 2

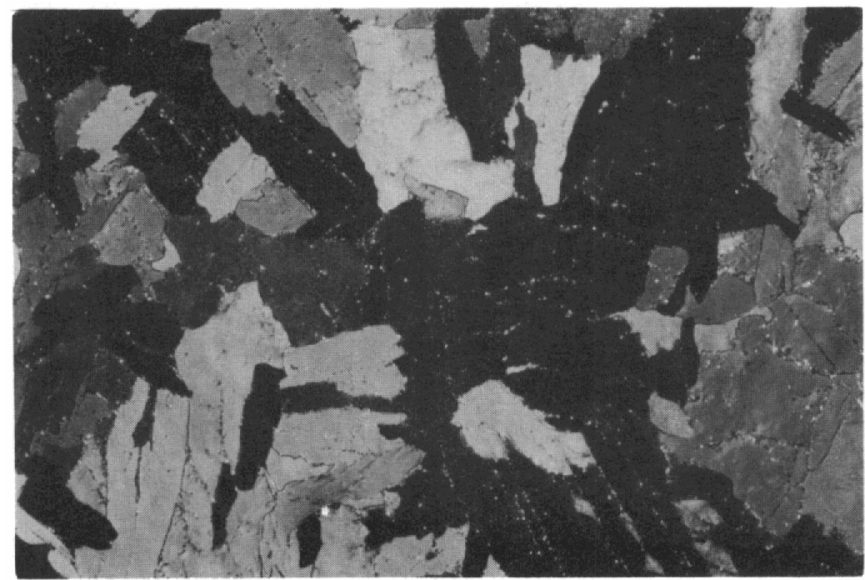

ANNEALING TEMPERATURE: $960^{\circ} \mathrm{C}$ STRUCTURE AT TEMPERATURE: $\beta$ ASTM GRAIN SIZE: 0 TO 2

FIGURE A.3. TYPICAL PHOTOMICROGRAPHS OF LARGE-GRAIN HEAT-TREATED ZIRCALOY-2. POLARIZED LIGHT 

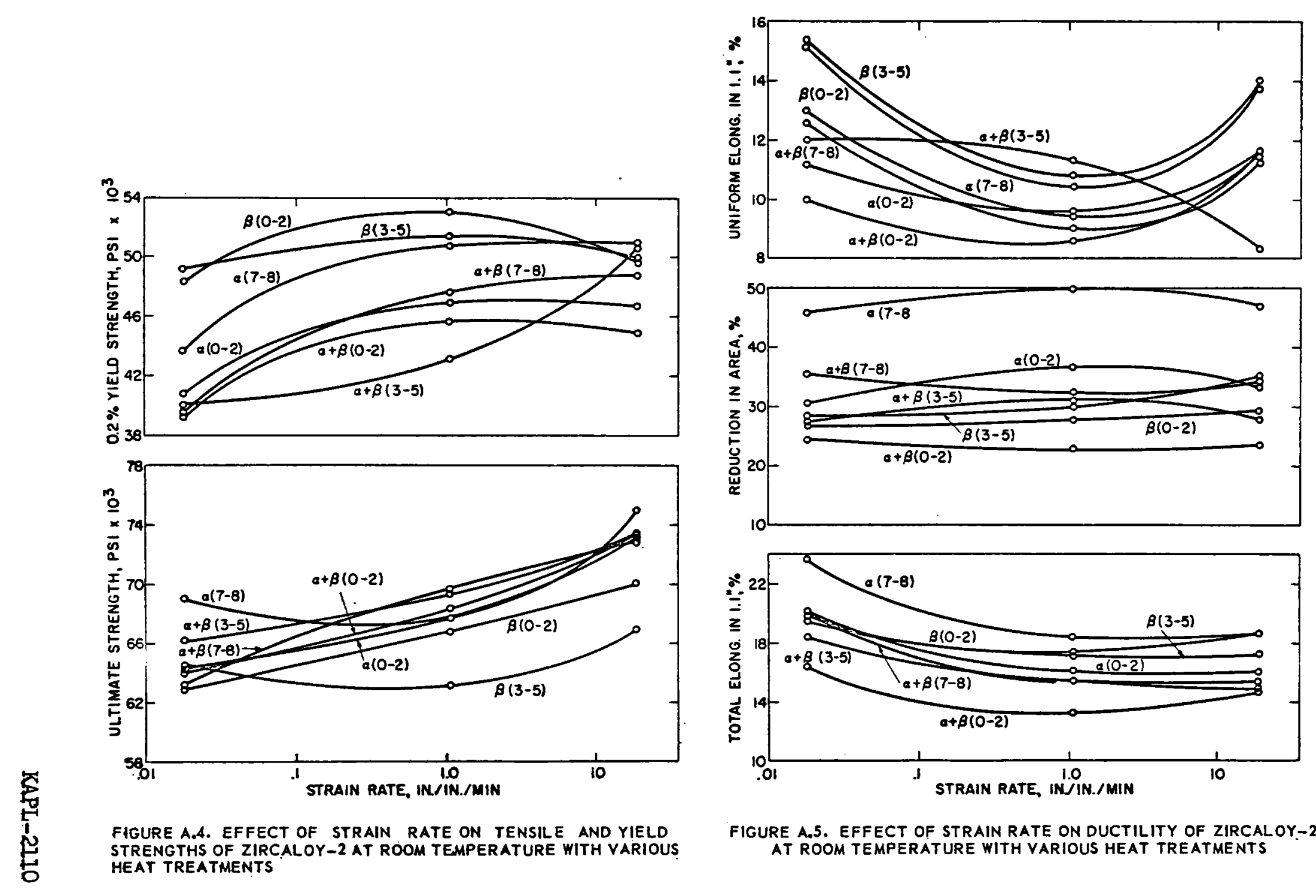

FIGURE A.5. EFFECT OF STRAIN RATE ON DUCTILITY OF ZIRCALOY-2 AT ROOM TEMPERATURE WITH VARIOUS HEAT TREATMENTS 

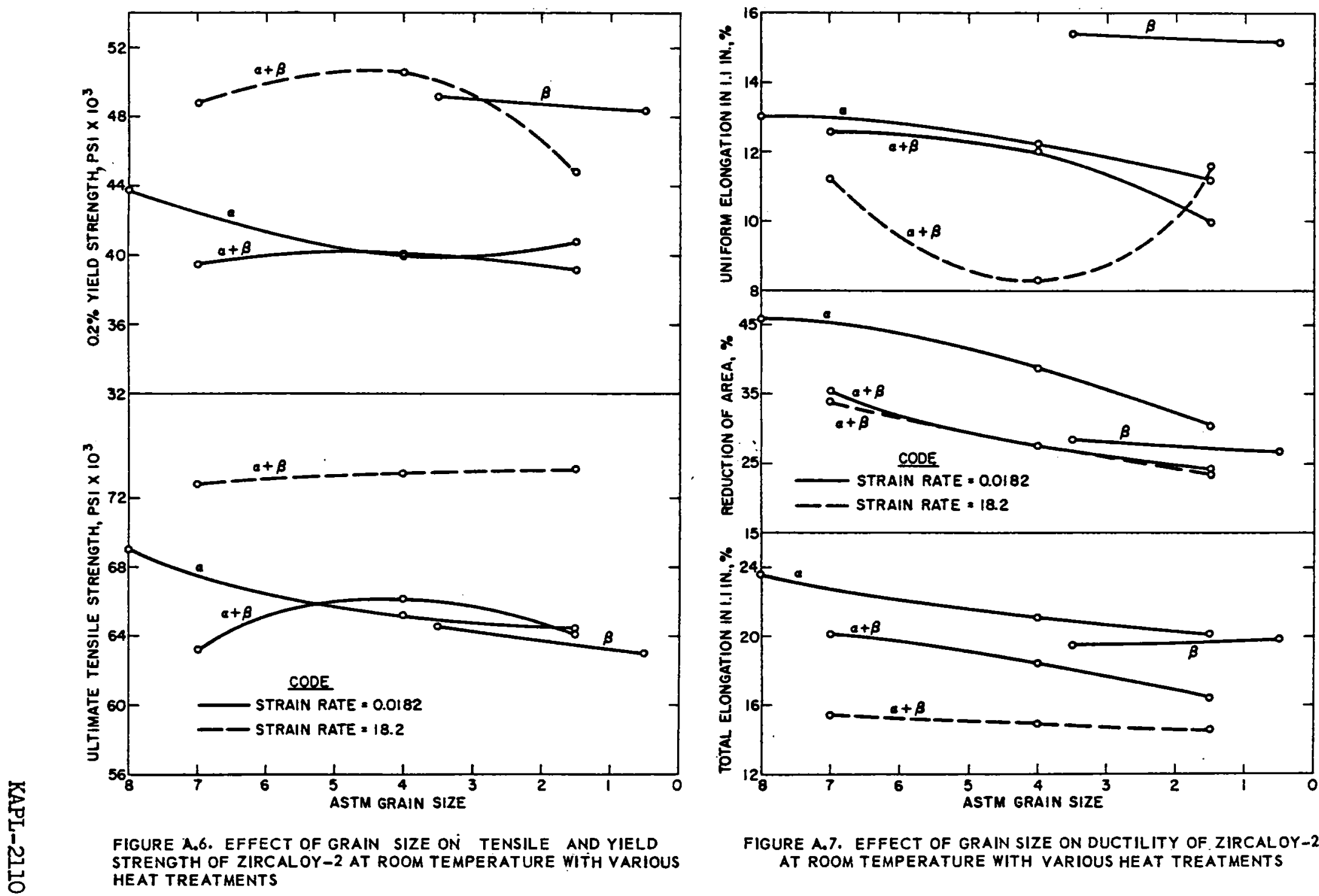

FIGURE A.7. EFFECT OF GRAIN SIZE ON DUCTILITY OF ZIRCALOY-2 AT ROOM TEMPERATURE WITH VARIOUS HEAT TREATMENTS 


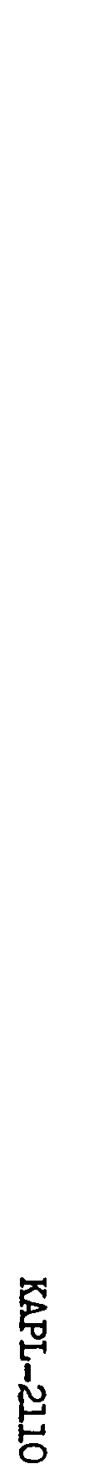

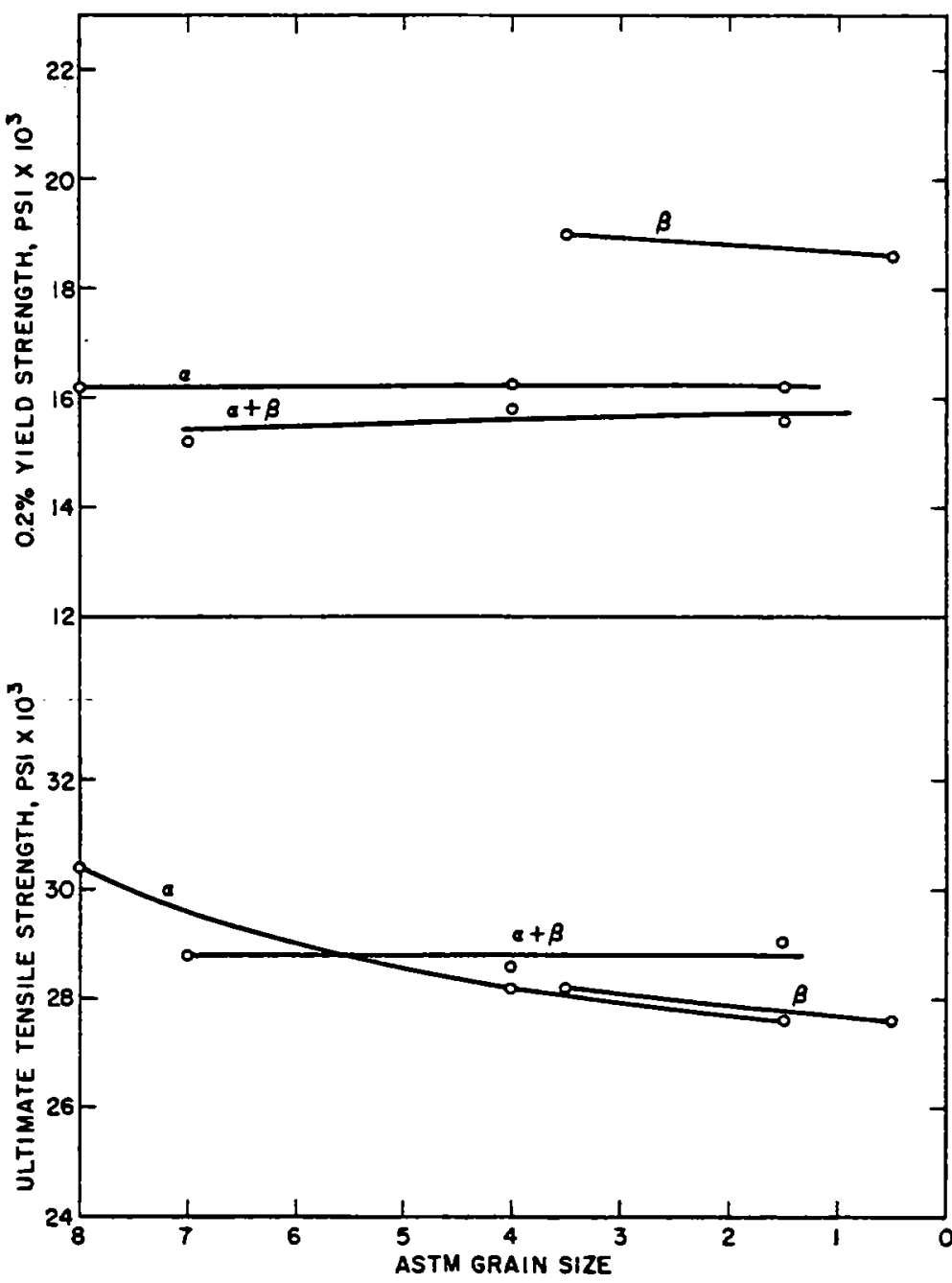

FIGURE A.8. EFFECT OF GRAIN SIZE ON TENSILE AND YIELD STRENGTHS OF ZIRCALOY-2 AT $600^{\circ} \mathrm{F}$ WITH VARIOUS HEAT TREATMENTS

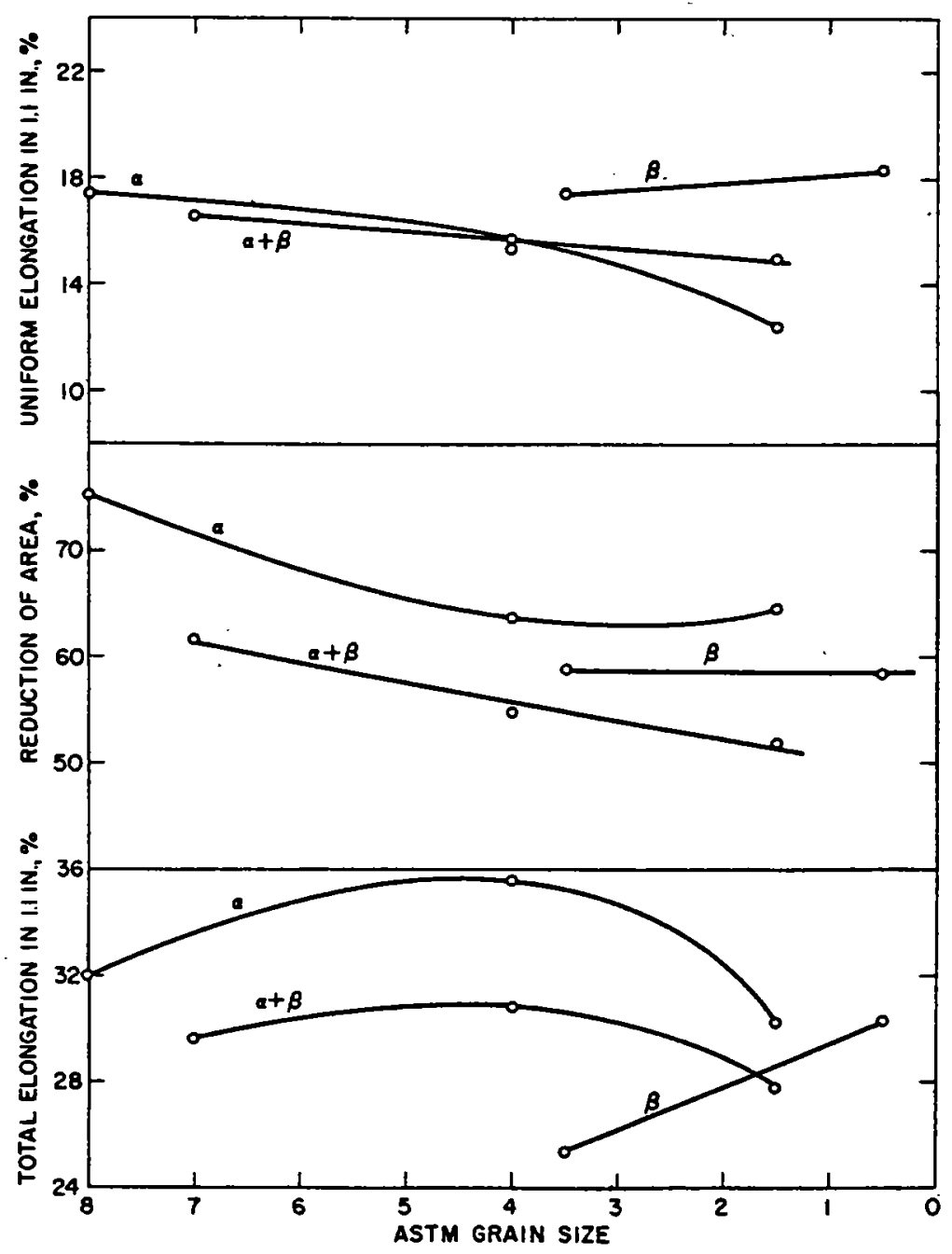

FIGURE A.9. EFFECT OF GRAIN SIZE ON DUCTILITY OF ZIRCALOY-2 AT $600^{\circ} \mathrm{F}$ WITH VARIOUS HEAT TREATMENTS 


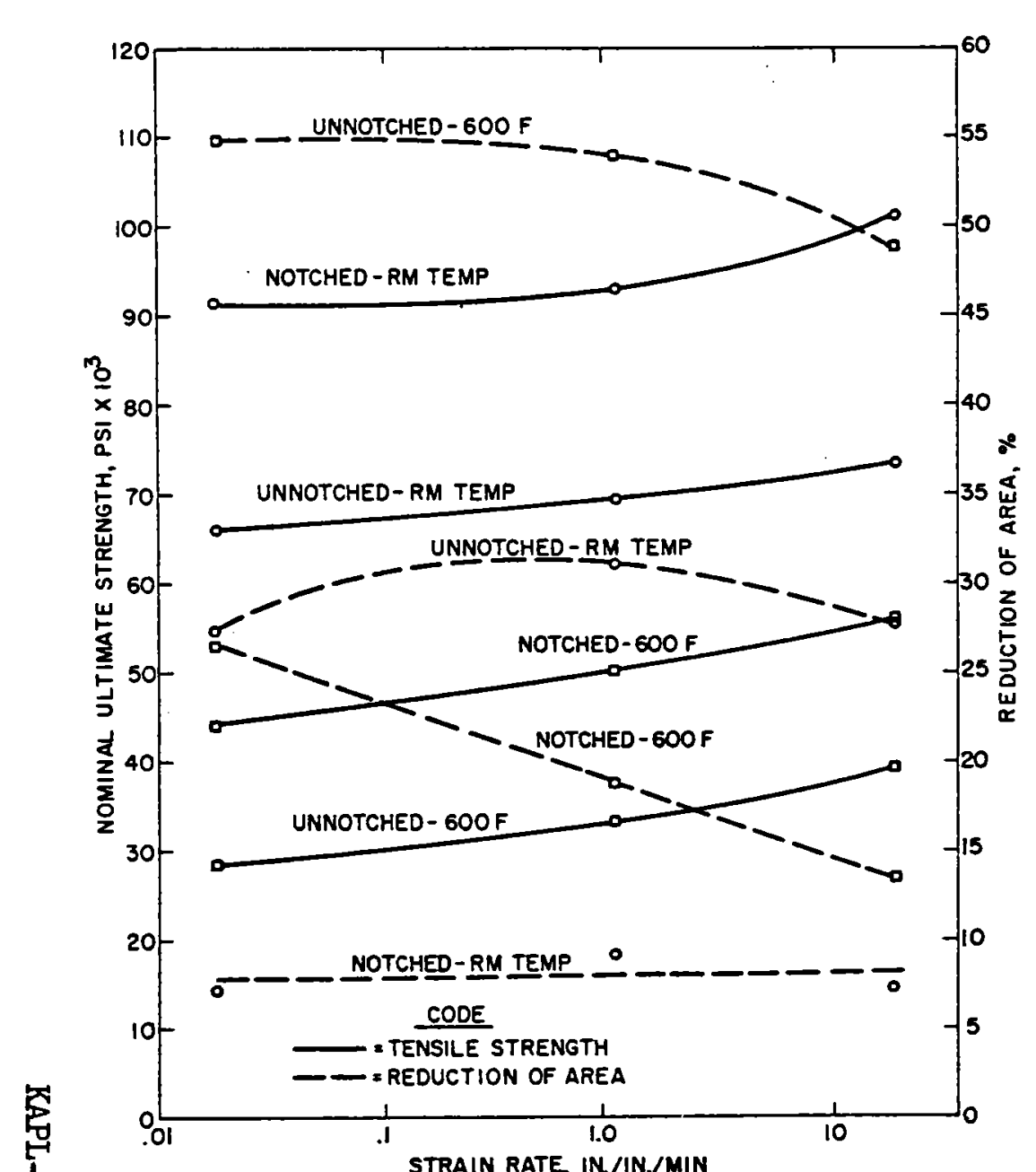

FIGURE A. 10. EFFECT OF STRAIN RATE ON TENSILE PROPERTIES OF NOTCHED AND UNNOTCHED ZIRCALOY -2 . CONDITIONS: $\alpha+\beta$ ANNEAL, GRAIN SIZE 3-5

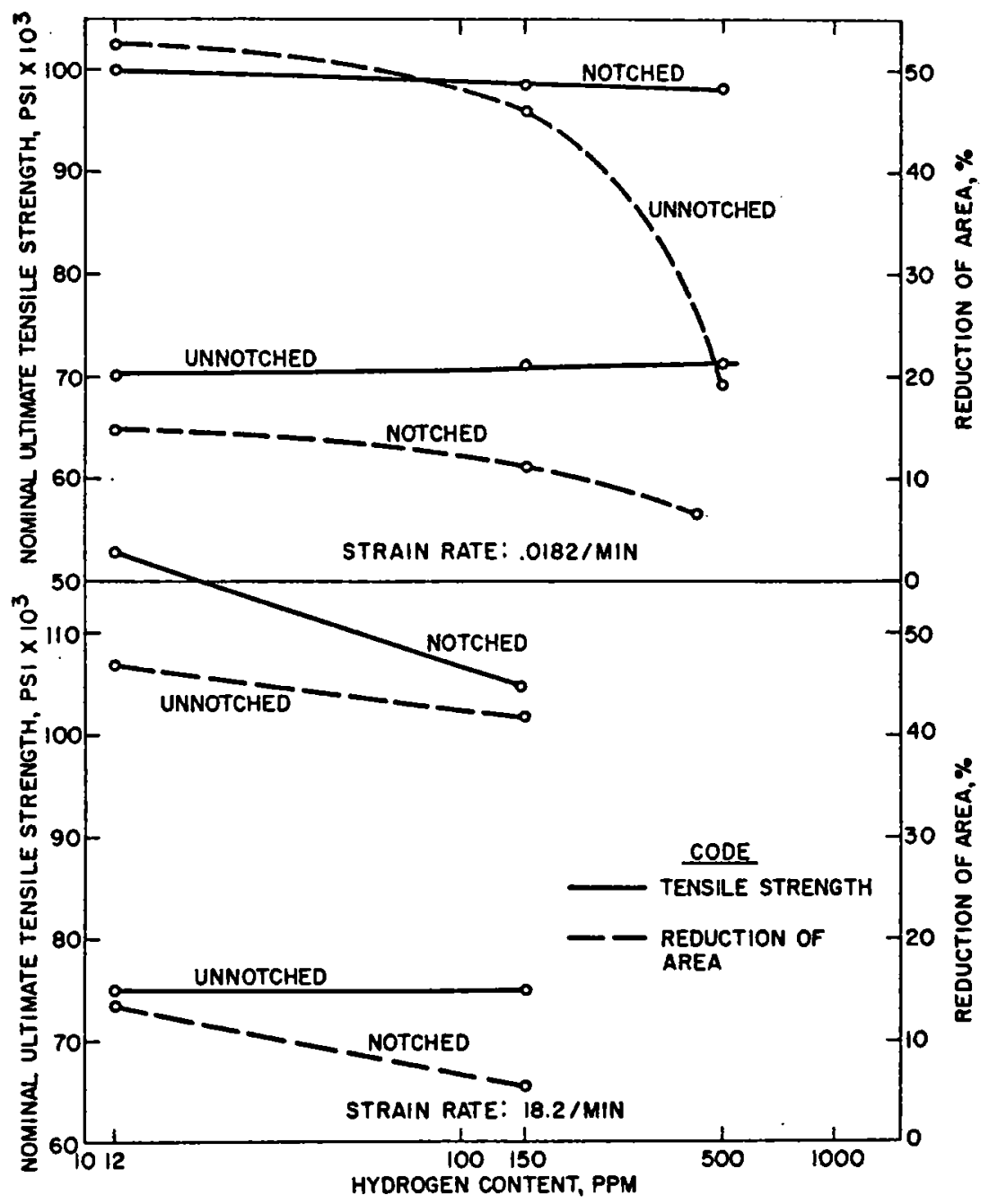

FIGURE A.11. EFFECT OF HYDROGEN CONTENT ON TENSILE PROPERTIES OF NOTCHED AND UNNOTCHED ZIRCALOY-2 AT ROOM TEMPERATURE AND 


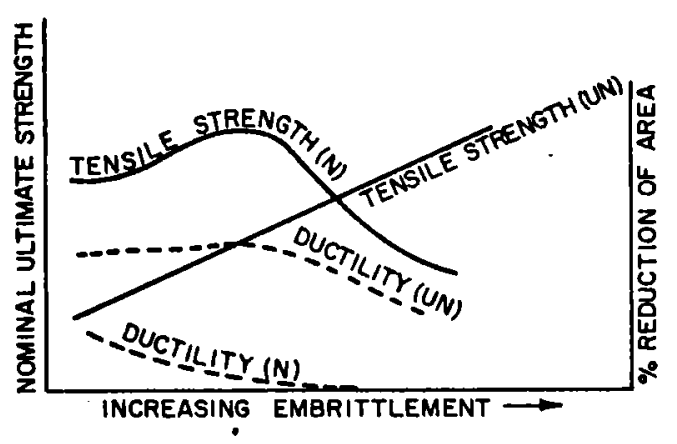

FIGURE A.12. SCHEMATIC DIAGRAM OF "NOTCH BRITTLE"“ BEHAVIOR

for the notched condition are difficult to measure and interpret when a large amount of ductility is present, and the apparent decrease with strain rate should, therefore, be interpreted with caution.

Figure A.Il shows the effect of increasing hydrogen content on the strength and ductility of notched and unnotched fine-grained (ASTM 7 to 8) alpha - Zircaloy-2 at room temperature at two strain

rates. The 500-ppm data were obtained from the previous results (see Figure 15). These results are quite interesting as they show that increasing hydrogen content seems to have a detrimental effect on ductility in the notched and unnotched conditions and, at the higher strain rate, on the notch strength. It has been shown ${ }^{24}$ for steels that the so-called "notch brittle" behavior can be represented schematically as shown in Figure A.12.

Although the notched strength ratios (defined as the ratio of notched tensile strength to unnotched tensile strength) in Figure A.8 are considerably above unity, the notch ductility at both striin rates decreases with increasing hydrogen content. As this dropoff is generally a prelude to "notch brittle" behavior, this may represent an area of some concern. However, without some knowledge of how the strength and ductility behave with still higher hydrogen contents, it is impossible to determine how much margin of ductile behavior remains.

The following conclusions may be drawn from these data:

1. Increasing strain rates in the range of $0.02 \mathrm{in.} / \mathrm{min}$ to $20 \mathrm{in./min} \mathrm{increase} \mathrm{strength} \mathrm{properties} \mathrm{to} \mathrm{a} \mathrm{moderate} \mathrm{ex-}$ tent at room temperature.

2. Increasing strain rates have little effect on the fracture, ductility at room temperature.

3. Of the three heat treatments studied, $\alpha, \alpha+\beta$, and $\beta$, the $\alpha+\beta$ treatment tends to produce lower strength and ductility, particularly at large grain sizes.

4. The effect of grain size per se is difficult to interpret. The strength properties are changed only slightly and the fracture ductility, as shown by the reduction in area, tends to decrease.

5. The effect of increasing hydrogen content on fine grained alpha - Zircaloy-2 causes a decrease in notched ductility with increasing hydrogen content. 


\section{APPENDIX B}

\section{POLE FIGURE OF ANNEALED ZIRCALOY-2}

The pole figure* for the annealed material that was used in this investigation is shown in Figure B.1. The material has a pronounced texture, with the (10י) poles aligned with the rolling direction. This is somewhat different from the case of $99.8 \%$ cold-reduced and recrystallized zirconfum, which has the (IID̃) poles allgned with the rolling direction, as well as intermediate pole densities. ${ }^{25}$ The exact reasons for these differences in orientation are not known, but may be related to the comparatively small degree of cold-working recelved by the zircaloy-2 as contrasted with the zirconium.

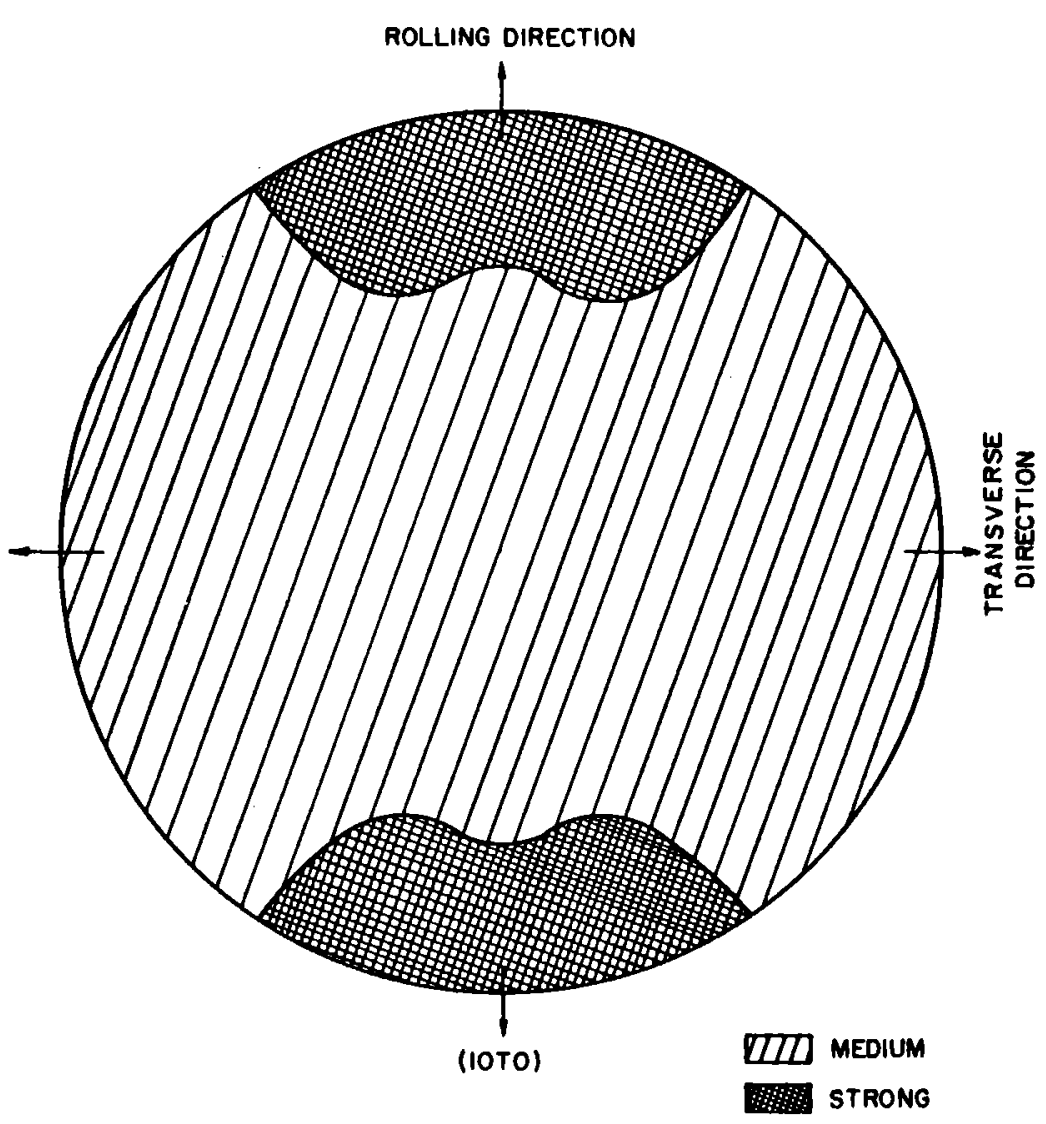

FIGURE B.I.

*The pole figure determination was performed by F. W. Kunz, KAPL, whose assistance in this area is gratefully acknowledged. 


